\title{
Position Paper On The Applicability Of SuPplemental StandaRdS TO THE UPPERMost AQUifer At THE URANIUM MiLl TAILINGS REMEDIAL ACTION VITRO Processing Site, Salt lake City, Utah
}

\section{DISCLAIMER}

This report was prepared as an account of work sponsored by an agency of the United States Government. Neither the United States Government nor any agency thereof, nor any of their employees, makes any warranty, express or implied, or assumes any legal liability or responsibility for the accuracy, completeness, or usefulness of any information, apparatus, product, or process disclosed, or represents that its use would not infringe privately owned rights. Reference herein to any specific commercial product, process, or service by trade name, trademark, manufacturer, or otherwise does not necessarily constitute or imply its endorsement, recommendation, or favoring by the United States Government or any agency thereof. The views and opinions of authors expressed herein do not necessarily state or reflect those of the United States Government or any agency thereof. 
This report has been reproduced from the best available copy. Available in paper copy and microfiche

Number of pages in this report: 114

DOE and DOE contractors can obtain copies of this report from:

Office of Scientific and Technical Information

P.O. Box 62

Oak Ridge, TN 37831

(615) 576-8401,

This report is publicly available from:

National Technical Information Service

Department of Commerce

5285 Port Royal Road

Springfield, VA 22161

(703) $487-4650$

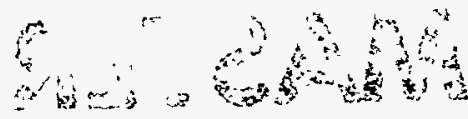


REV. 0

POSITION PAPER ON THE APPLICABILITY OF SUPPLEMENTAL STANDARDS TO THE UPPERMOST AQUIFER AT THE URANIUM MILL TAILINGS VITRO PROCESSING SITE, SALT LAKE CITY, UTAH

March 1996

Work performed under DOE Contract No. DE-AC04-91AL62350.

\section{Prepared for}

U.S. Department of Energy Grand Junction Projects Office

Prepared by Jacobs Engineering Group Inc. Albuquerque, New Mexico

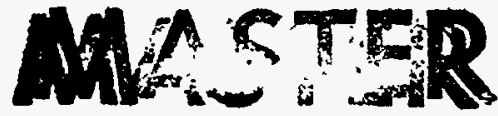




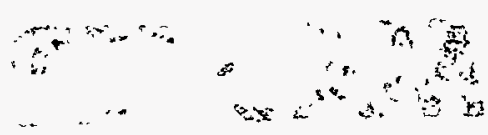

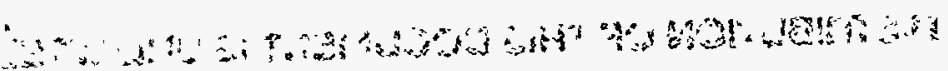


TABLE OF CONTENTS

Section

Page

1.0 INTRODUCTION

2.0 SITE CONCEPTUAL MODEL SUMMARY .............................................. $2-1$

2.1 Site Location ............................................................................... $2-1$

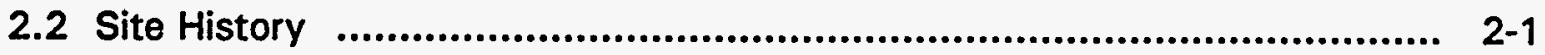

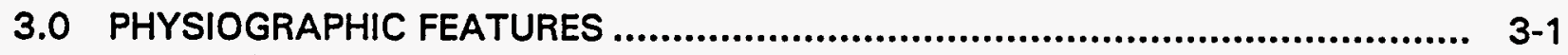

3.1 Hydrogeology ............................................................................. 3-1

3.1.1 Shallow unconfined aquifer .................................................. 3-1

3.1.2 Confined aquifer ............................................................... 3-5

3.2 Background ground water quality summary........................................ $3-6$

3.2.1 Confined aquifer water quality............................................ 3-6

3.2.2 Background water quality in the shallow unconfined aquifer .......... 3-7

3.3 Magnitude and extent of contamination.............................................. 3-14

3.4 Surface water results ...................................................................... 3-26

3.4.1 Mill Creek ......................................................................... 3-26

3.4.2 Jordan River................................................................. 3-28

4.0 LAND-USE EVALUATION................................................................. 4-1

4.1 Current and projected uses of the uppermost aquifer ............................. 4-1

4.1.1 Off-site land and shallow ground water uses................................ 4-1

4.1.2 On-site land and shallow ground water uses ............................. 4-2

4.2 Risk-based evaluation of current and projected land uses ....................... 4-5

4.2.1 Risk-based evaluation of off-site land uses................................ 4-5

4.2.2 Risk-based evaluation of on-site land uses ............................... 4-8

5.0 APPLICABILITY OF SUPPLEMENTAL STANDARDS.................................... $5-1$

5.1 Definition of supplemental standards.............................................. $5-1$

5.1.1 Subpart B - Background levels, maximum concentration limits, alternate concentration limits, monitoring, and natural flushing ...... 5-1

5.1.2 Subpart C - Application of supplemental standards ..................... 5-2

5.1.3 Demonstration of supplemental standard applicability .................. $5-2$

5.2 Summary and conclusions ......................................................... $5-3$

5.2.1 Site conceptual model ....................................................... 5-3

5.2.2 Risk based evaluation of contaminant effects on current and projected land uses .............................................................. $5-4$

5.2.3 Possible use of the Vitro property .......................................... 5-5

5.2.4 Evaluation of the application of supplemental standards............... 5-5

5.2.5 Uncertainties................................................................... $5-6$

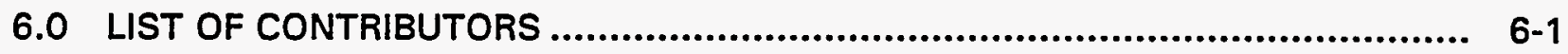

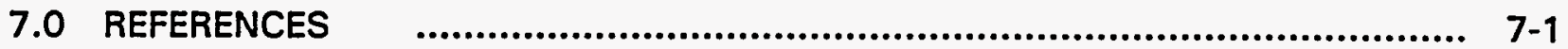




\section{TABLE OF CONTENTS (Concluded)}

ATTACHMENT 1 - SUMMARY OF SUPPLEMENTAL STANDARDS-RELATED FIELD INVESTIGATION AT THE UMTRA VITRO PROCESSING SITE, SALT LAKE CITY, UTAH 


\section{LIST OF FIGURES}

Fiqure

2.1 South Clive disposal site and Salt Lake City processing site locations....

2.2 Aerial photograph of the Vitro processing site (2/81), Salt Lake

City, Utah

3.1 Site map showing logging and sampling locations, Salt Lake City, Utah,

Vitro processing site

3.2 Site map showing water table in the shallow, unconfined aquifer, Salt Lake City, Utah, Vitro processing site

4.1 Area of water use survey upgradient, crossgradient, and downgradient Salt Lake City, Utah, site. 


\section{LIST OF TABLES}

Table

Page

3.1 Comparison of ground water quality in the confined aquifer at the

Vitro site to water quality in public supply wells west of the Jordan River.

3.2 Comparison of ground water quality in the unconfined aquifer at the

Vitro site to general water in the unconfined aquifer in the Central

Salt Lake valley.

3.3 Ground water quality in the shallow, unconfined aquifer associated with

former smelters in the Salt Lake City valley.

3.4 Comparison of the composition of Salt Lake Valley airbornes to average western U.S. soils.

3.5 Summary of ground water quality data in the shallow unconfined aquifer at Salt Lake City, Utah, $1990-1995$.

3.6 Surface water quality data for Mill Creek, Salt Lake City, Utah, site.

3.7 Surface water quality data of Mill Creek and Jordan River, Salt Lake City, Utah, site

4.1 Private ground water wells in the Vitro site area

4.2 Possible uses of shallow private wells upgradient, crossgradient, and downgradient of the site

4.3 Comparison of off-site shallow ground water constituent concentrations to risk-based benchmark concentrations.

4.4 Comparison of the off-site shallow ground water constituent concentrations to screening benchmark concentrations for terrestrial plants

4.5 Incidental dermal contact with surface-exposed on-site ground water.

4.6 Comparison of on-site Shallow ground water concentrations to screening benchmark concentrations for terrestrial plants and aquatic life. 


\section{LIST OF ACRONYMS}

\section{Acronym}

AEC

DOE

EPA

HP

MK-F

NRC

OCS

OSCR

QA

QAPP

QC

RAC

RAC-AL

RAIP

RAP

STP

TAC

UMTRA

UMTRCA

VP

\section{Definition}

Atomic Energy Commission

U.S. Department of Energy

U.S. Environmental Protection Agency

health physics

MK-Ferguson Company

U.S. Nuclear Regulatory Commission

Opposed Crystal System

on-site construction review

quality assurance

quality assurance program plan

quality control

Remedial Action Contractor

Remedial Action Contractor - Albuquerque Office

remedial action inspection plan

remedial action plan

staff technical position paper

Technical Assistance Contractor

Uranium Mill Tailings Remedial Action

Uranium Mill Tailings Radiation Control Act

vicinity property 



\subsection{INTRODUCTION}

This report documents the results of the evaluation of the potential applicability of supplemental standards to the uppermost aquifer underlying the Uranium Mill Tailings Remedial Action (UMTRA) Project, Vitro Processing Site, Salt Lake City, Utah. There are two goals for this evaluation: provide the landowner with information to make an early qualitative decision on the possible use of the Vitro property, and evaluate the proposed application of supplemental standards as the ground water compliance strategy at the site. Justification of supplemental standards is based on the contention that the uppermost aquifer is of limited use due to wide-spread ambient contamination not related to the previous site processing activities.

In support of the above, this report discusses the site conceptual model for the uppermost aquifer and related hydrogeological systems and establishes regional and local background water quality. This information is used to determine the extent of site-related and ambient contamination. A risk-based evaluation of the contaminants' effects on current and projected land uses is also provided.

Reports of regional and local studies and U.S. Department of Energy (DOE) site investigations provided the basis for the conceptual model and established background ground water quality. In addition, a limited field effort (4 through 28 March 1996) was conducted to supplement existing data, particularly addressing the extent of contamination in the northwestern portion of the Vitro site and site background ground water quality. Results of the field investigation were particularly useful in refining the conceptual site model. This was important in light of the varied ground water quality within the uppermost aquifer.

Finally, this report provides a critical evaluation, along with the related uncertainties, of the applicability of supplemental standards to the uppermost aquifer at the Salt Lake City Vitro processing site. 



\subsection{SITE CONCEPTUAL MODEL SUMMARY}

\subsection{SITE LOCATION}

The Salt Lake City uranium ore processing site (the Vitro site) is between the Wasatch Mountains to the east and the Oquirrh Mountains to the west, 4 miles (mi) (6 kilometers [km]) south-southwest of the center of Salt Lake City, in the city of South Salt Lake. Figure 2.1 shows the site location.

\subsection{SITE HISTORY}

In 1941, a large smelting operation known as Calunite Smelter, Inc., was completed at the Vitro site. In 1946, the plant became known as the Vitro Chemical Company Calunite Plant. From 1941 through 1951, this smelter processed aluminum from aluminite. In May 1951, the Vitro plant began processing uranium ore under contract to the U.S. Atomic Energy Commission (AEC). From 1951 to 1964 , the Vitro plant processed uranium ores by acid leaching. In 1965 , the mill converted to the production of vanadium. Vanadium production ceased in 1968 and the plant was dismantled in 1970. A detailed description of uranium and vanadium extraction processes used at the Vitro site is given in the Baseline Risk Assessment of Ground Water Contamination at the Uranium Mill Tailings site Near Salt Lake City, Utah (DOE, 1995a).

Figure 2.2 shows the Vitro mill site after the plant was dismantled. The eastern portion of the site was used for the ore processing mill, ore storage, and transportation facilities (FB\&D, 1981). The remainder of the site served as a tailings (pond) area for the mill.

Remedial action at the Vitro site occurred from January 1985 to March 1987. A total of $2,798,000$ cubic yards $\left(\mathrm{yd}^{3}\right)\left(2,139,000\right.$ cubic meters $\left.\left[\mathrm{m}^{3}\right]\right)$ of tailings was removed from the site and stabilized in a disposal cell at Clive, Utah (approximately $85 \mathrm{mi}[140 \mathrm{~km}]$ west of Salt Lake City). The state of Utah was the remedial action contractor. The surface cleanup left the former Vitro site free of process-related soil contamination (except for the areas where supplemental standards for radium-226 and thorium-230 were applied to parts of the site) (DOE, 1994). Clean fill was placed in all excavated areas and the ground was recontoured and revegetated. 


\section{Figure 2.1}

South Clive Disposal Site and

Salt Lake City Processing Site Locations
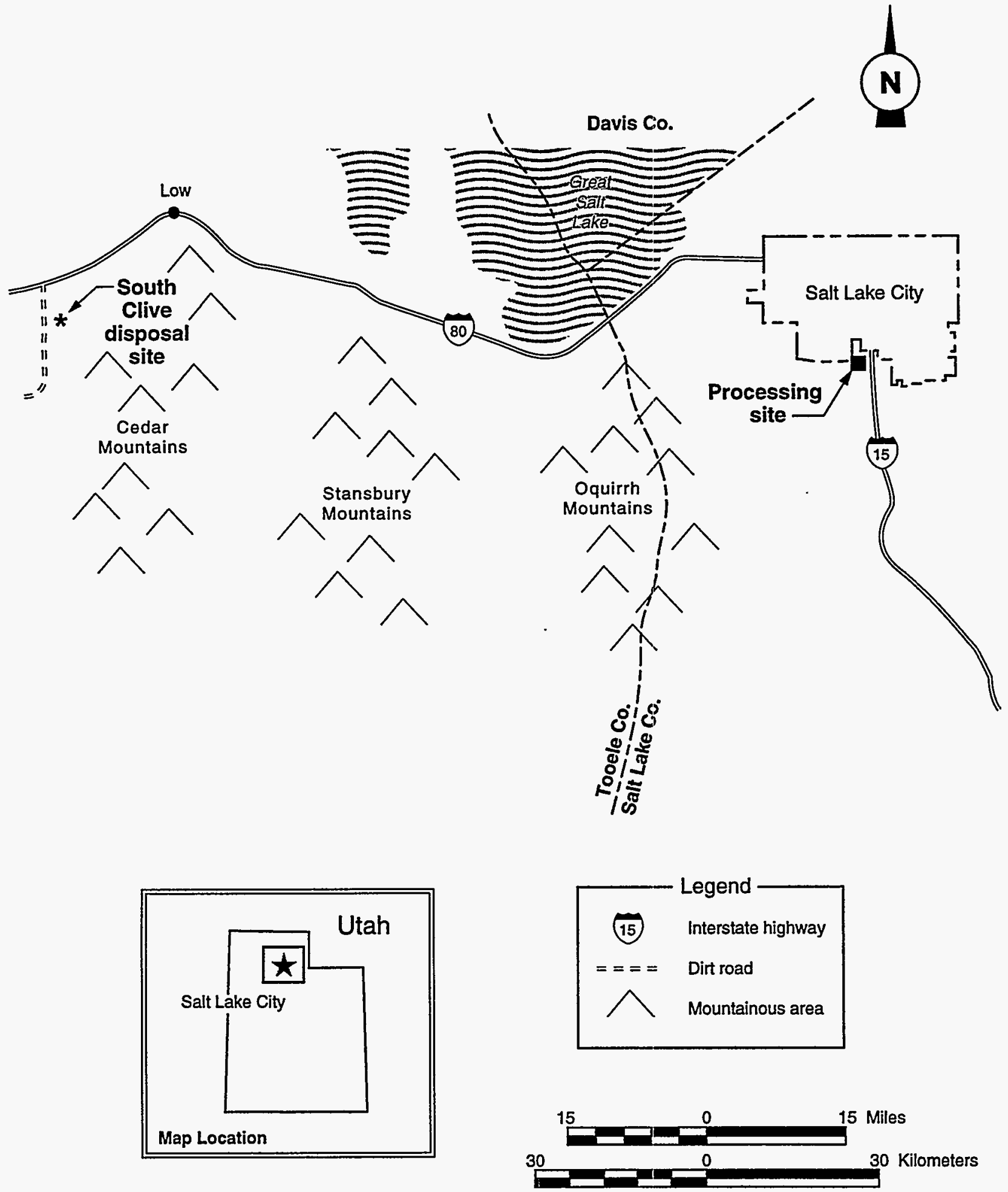

MAC: STTESLL/SUPP STAND/SITELOC 
Figure 2.2

Aerial Photograph of the Vitro Processing Site (2/81), Salt Lake City, Utah

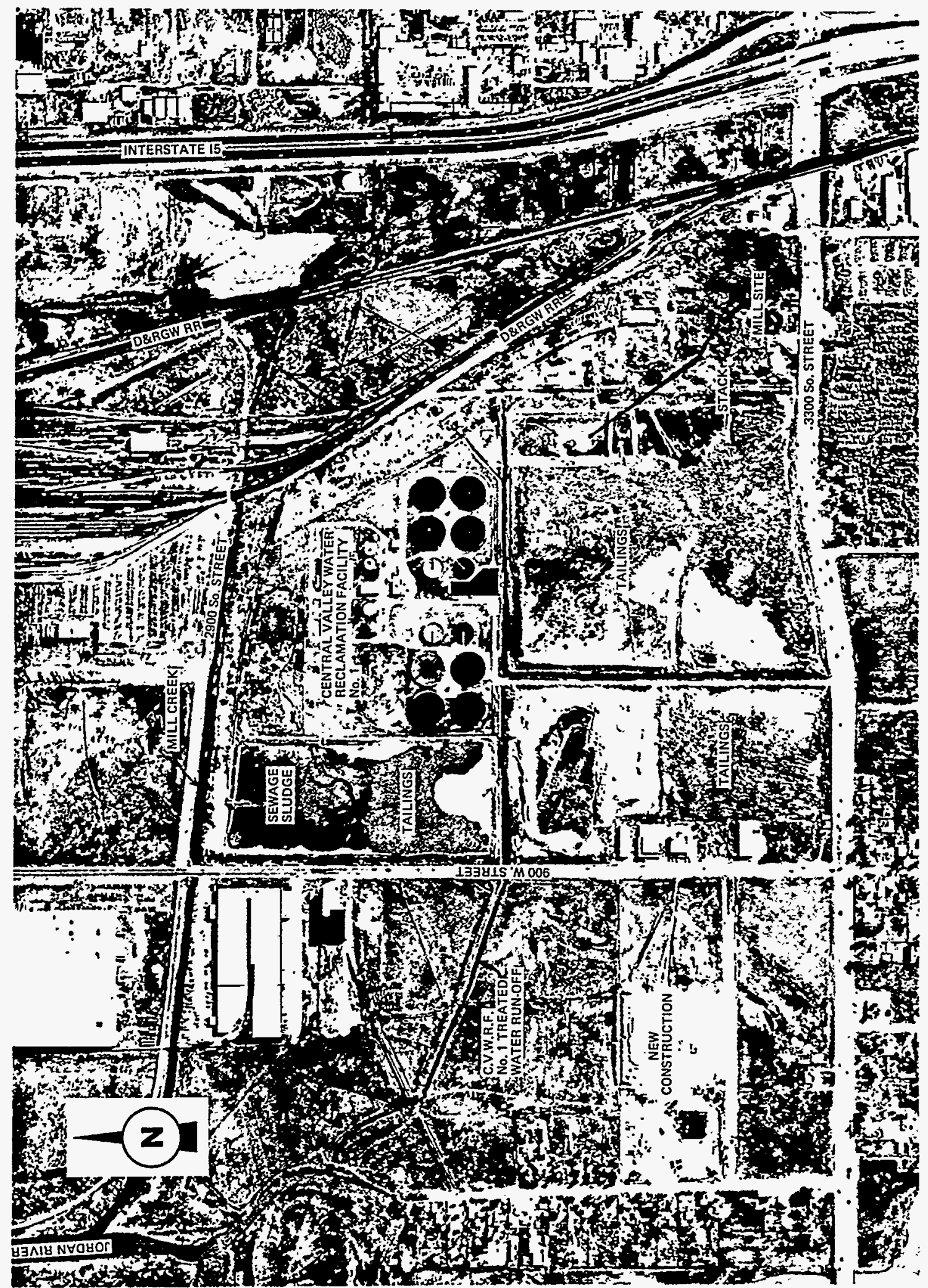

MAC: SITE/SLC/SUPP STAND/PASTEUP 


\subsection{PHYSIOGRAPHIC FEATURES}

The Jordan River, the main drainage for the Salt Lake City valley, flows to the north about 1500 feet ( $\mathrm{ft}$ ) $(500$ meters [m]) west of the site. Mill Creek, which originates in the Wasatch Mountains, flows westerly across the northern boundary of the Vitro processing site and the Central Valley Water Reclamation Facility (CVWRF) (Figure 2.2). The area is characterized by very gentle topography in which anthropogenic changes are more apparent than the original topographic features. Sewer mains to the CWWRF were buried at a depth of approximately $20 \mathrm{ft}(6 \mathrm{~m})$ from east to west across the site and from south to north on the west side of 900 West Street. The foundations and buried maintenance tunnels of the CVWRF are at depths up to $23 \mathrm{ft}(7 \mathrm{~m})$.

\subsection{HYDROGEOLOGY}

After site surface remediation, the upper 4 to $13 \mathrm{ft}(1.2$ to $3.9 \mathrm{~m})$ of soil were replaced with clean, sandy-gravel fill material. The lithology underlying this fill at the Vitro processing site consists of a thick sequence of Quaternary lacustrine and fluvial deposits with minor alluvial overburden. These unconsolidated deposits below the site are approximately $700 \mathrm{ft}(210 \mathrm{~m}$ ) thick (Arnow et al., 1970). Tertiary deposits underlie the Quaternary deposits to a depth of approximately $1200 \mathrm{ft}(370 \mathrm{~m})$ (Mattick, 1970). These Tertiary deposits consist of semiconsolidated clay, sand, and gravel interspersed with lava and cemented layers of sand and gravel (Arnow et al., 1970).

The ground water regime in the vicinity of the Vitro processing site is generally characterized by two aquifer systems: a shallow, unconfined system and a deeper, confined system. The two aquifers are separated by interbedded layers of lowpermeability clays and silts. The shallow unconfined aquifer extends down to $50 \mathrm{ft}$ $(15 \mathrm{~m})$, with static water levels at 5 to $10 \mathrm{ft}(1.5$ to $3 \mathrm{~m})$ below ground level. Wells in the confined aquifer, at depths from 70 to $330 \mathrm{ft}(20$ to $100 \mathrm{~m})$ below the ground surface, are under substantial artesian pressure, with ground water flowing from several wells under as much as $15 \mathrm{ft}(4.6 \mathrm{~m})$ of head above ground level. Therefore, the potential for vertical ground water flow is upwards from the confined into the unconfined aquifer. Near the site, lateral ground water flow in both aquifers is predominantly to the west-northwest, toward the Great Salt Lake. Water in the shallow unconfined aquifer near the site discharges to the Jordan River. According to the U.S. Geological Survey (USGS), the Jordan River is a headdependent boundary (Lambert, 1995); if the water level in the aquifer adjacent to the river is higher than the water level in the river, then ground water will discharge to the river. If the water level in the aquifer is lower than the river, then river water will recharge the aquifer. In either case, ground water will not flow under the river because the river acts as a hydrologic barrier.

\subsubsection{Shallow unconfined aquifer}

In the vicinity of the former tailings pile, the upper, unconfined aquifer is approximately $50 \mathrm{ft}(15 \mathrm{~m})$ thick. Ground water levels in the unconfined aquifer 
range from 5 to $15 \mathrm{ft}(1.5$ to $4.6 \mathrm{~m})$ or more below the ground surface. The water level is highest in March or April and lowest in mid- to late summer. Topographic lows east of the site are perennially marshy. Regionally, the ground water flows primarily from southeast to northwest. Figure 3.1 gives the locations of monitoring wells, well points, and hydropunch sampling sites used to determine water levels. Locally, however, recent data (March 1996) indicate that ground water flows toward the site from all directions in response to dewatering activities at the CVWRF (Figure 3.2).

Near the site, the shallow unconfined aquifer consists of unconsolidated fluvial deposits of the Jordan River and Mill Creek. There appear to be three general lithologic types in the upper $40 \mathrm{ft}$ of the aquifer, based on results of cone penetrometer data collected in March 1996 (Plate 1; Attachment 1). The first lithologic type is gravely sand and sand, which tends to fine upward (for example, 22 to $8 \mathrm{ft}$ [6.7 to $2.4 \mathrm{~m}$ ], HP-10, Plate 1). This lithology is interpreted as fluvial channel (point-bar) deposits. The second lithologic type is thinly interbedded fine sand and clay sequences, which tend to coarsen upward (for example, 40 to $28 \mathrm{ft}$ [1 2 to $8.5 \mathrm{~m}$ ], HP-14, Plate 1). These are interpreted as flood splay deposits. The third lithologic type is silty clay and clayey silt, interpreted as floodplain deposits (for example, 34 to $24 \mathrm{ft}$ [10 to $7.3 \mathrm{~m}$ ], HP-15, Plate 1). Additionally, man-made fill, to depths of 4 to $7 \mathrm{ft}(1$ to $2 \mathrm{~m})$, occur in several areas on and around the site (HP-1, -2, -6, -12, and -13; Plate 1).

The channel deposits occur in the upper portion of the unconfined aquifer, from 8 to $35 \mathrm{ft}(2.4$ to $11 \mathrm{~m})$ below land surface. The bases of these deposits vary in depth from 13 to $35 \mathrm{ft}(4$ to $11 \mathrm{~m})$. These channel deposits are not present everywhere; in some areas, the upper 30 to $36 \mathrm{ft}(9.1$ to $11 \mathrm{~m})$ of the unconfined aquifer consist of floodplain deposits (HP-1, -2, and -4; Plate 1 ).

Floodplain deposits also underlie the shallow channel deposits in most areas near the site. These are relatively impermeable. There is a zone of thinly interbedded sand and clay beneath the floodplain deposits, interpreted as flood splay deposits. This zone occurs from about 30 to $40 \mathrm{ft}(9.1$ to $12 \mathrm{~m})$ below the surface and is separated from the shallow channel sands by floodplain clays and clayey silts. However, in 2 of the 10 locations sampled (HP-10 and -12, Plate 1), the base of the channel sand is in contact with these deeper splay deposits.

On-site, there appear to be two channel sands in the area of HP-12: a lower channel (from 18 to $36 \mathrm{ft}$ [5.5 to $11 \mathrm{ml}$ ) and a shallow channel (from 8 to $14 \mathrm{ft}$ [2.4 to $4.3 \mathrm{~m}$ ] below land surface). These are separated by a clay unit at 14 to 18 $\mathrm{ft}(4.2$ to $5.5 \mathrm{~m})$. The upper channel is thought to have been deposited by Mill Creek, based on descriptions of a shallow sand, trending east-west, encountered during surface remediation of the site. The deeper channel is likely a Jordan River channel deposit (point-bar deposit). Deeper, thicker Jordan River channel deposits also occur at locations HP-6, $-10,-12$ and -13 (Plate 1). Shallower sands, likely older Mill Creek channels, occur at locations HP-15 and -16 (Plate 1). 
Figure 3.1

Site Map Showing Logging and Sampling Locations

Salt Lake City, Utah, Vitro Processing Site

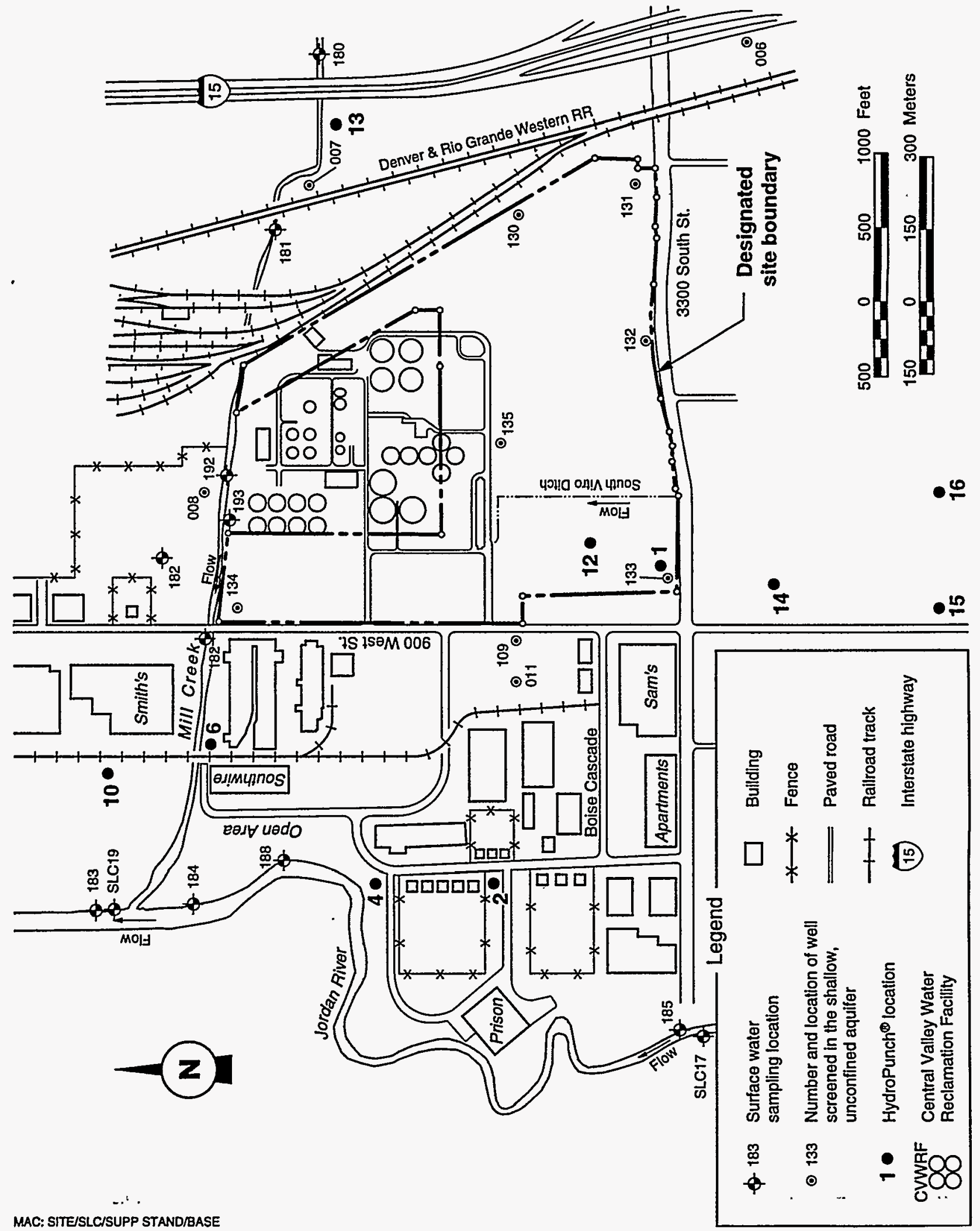




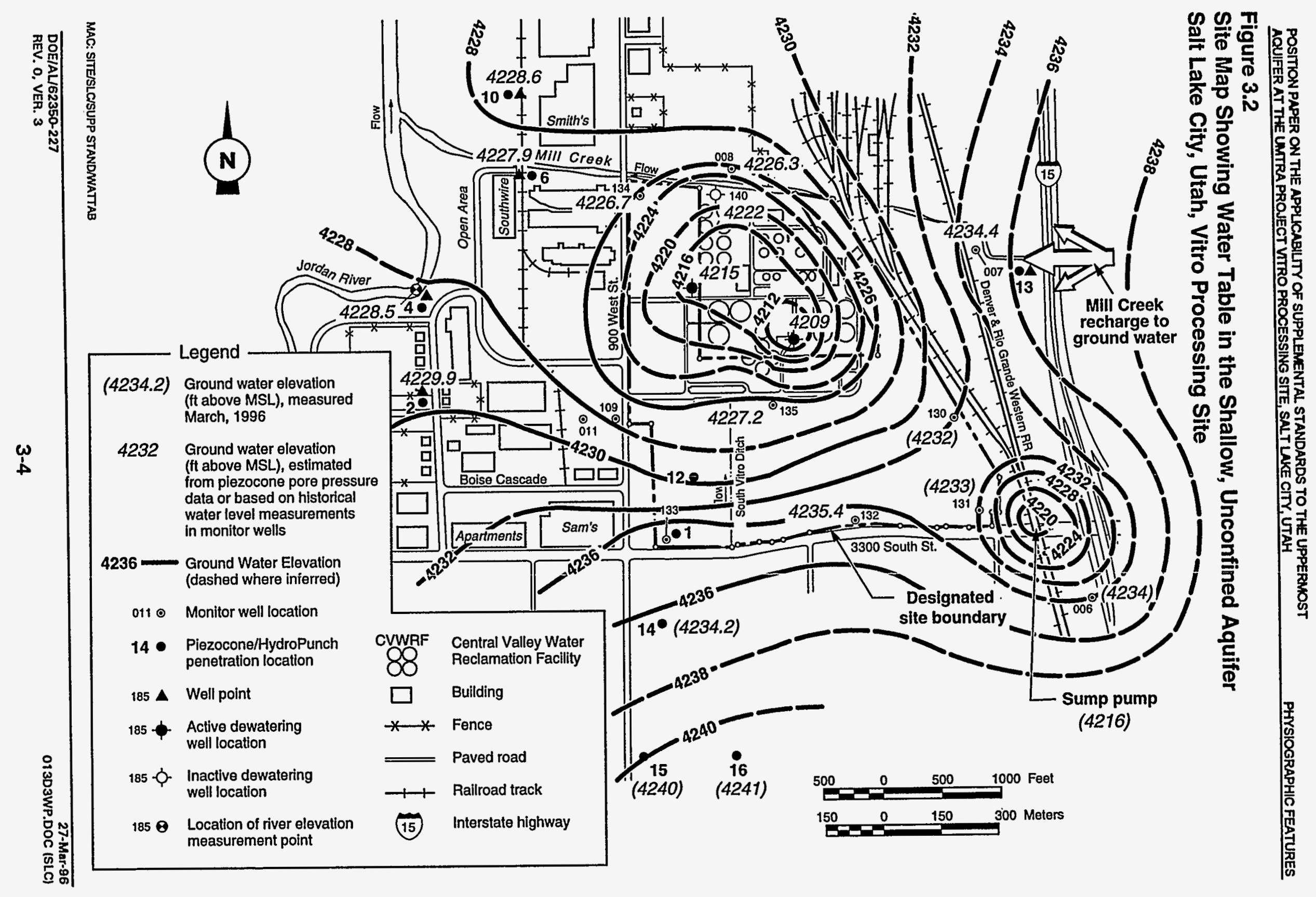


The channel sands are the best ground water producers. A shallow ( $<30 \mathrm{ft}$ ) dewatering well at the CVWRF, pumped since January 1995, yields approximately 300 gallons (gal) (1100 liters [L]) per minute. This well is screened in a channel sand. Other wells screened in thin splay sands and in the floodplain deposits are poor ground water producers and may yield less than 2 gal $(4 \mathrm{~L})$ per minute.

The hydraulic conductivities, determined from slug tests and an aquifer test conducted in 1992, ranged from 0.37 to $8.9 \mathrm{ft}(0.11$ to $2.7 \mathrm{~m})$ per day (Calculation No. SLC-07-92-14-03-00; TAC, 1992). A range of average linear ground water velocities in the shallow unconfined aquifer was calculated using the range of hydraulic conductivities, a hydraulic gradient of 0.005 , and an assumed effective porosity of 0.20 . Using Darcy's Law, the average linear velocities for ground water flow in the shallow unconfined aquifer range from approximately 3 to $80 \mathrm{ft}$ (1 to $20 \mathrm{~m}$ ) per year under normal site conditions when the dewatering wells are inactive.

The major sources of recharge to the unconfined aquifer are precipitation infiltration and upward leakage from the confined aquifer. Ground water in the unconfined aquifer generally discharges to surface water drainages such as Mill Creek and the Jordan River (Figure 2.2). Geochemistry and water level data suggest that Mill Creek is a sources of recharge near the Vitro site. However, a highway drain at the 3300 South Street underpass below the Denver \& Rio Grande Western Railroad locally influences ground water flow in the unconfined aquifer. Ground water entering the drain is pumped out by a lift station into a culvert that discharges into the head of South Vitro Ditch. Ground water levels in the area indicate that a local ground water cone of depression in the southeast corner of the site draws ground water from that area toward the drain (Figure 3.2). A significant depression in the water table has been created in the vicinity of CVWRF (Figure 3.2) from dewatering wells that were installed or reactivated for expansion of the facility. These wells are estimated to extract a total of about 400 to 500 gal $(1500$ to $1900 \mathrm{~L}$ ) per minute.

A 28-acre (ac) (11-hectare [ha]) golf driving range has been constructed on the southeast corner of the site. Irrigation of the golf course has a potential to recharge minor amounts of water to the shallow unconfined aquifer.

\subsubsection{Confined aquifer}

The confined aquifer begins approximately $70 \mathrm{ft}(20 \mathrm{~m})$ below the ground surface at the site. Ground water is under substantial artesian pressure in this aquifer. Hydraulic head levels range from approximately $8 \mathrm{ft}(2.5 \mathrm{~m})$ above the ground surface for the well screened at $70 \mathrm{ft}(20 \mathrm{~m})$, to $15 \mathrm{ft}(4.5 \mathrm{~m})$ above ground surface for the wells screened at a depth of approximately $130 \mathrm{ft}(40 \mathrm{~m})$. Near the Jordan River, this confined (artesian) aquifer system extends to depths of 500 to $800 \mathrm{ft}(150$ to $240 \mathrm{~m}$ ) below the ground surface (Hely et al., 1971).

The major sources of recharge to the confined aquifer are precipitation infiltration and snowmelt along the flanks of the Wasatch and Oquirrh Mountains. Beneath the site, the ground water in this aquifer flows west-northwest. Natural discharge is 
upward to the unconfined aquifer system. Artificial discharge includes pumpage of wells completed in the confined aquifer system.

The relatively good water quality of the confined aquifer is maintained by the upward vertical hydraulic gradient between the two aquifers, which prevents downward water migration from the unconfined aquifer. Modeling of the confined aquifer by the USGS (Waddell et al., 1987) indicates that, with an increase in ground water withdrawals of about $60 \%$ from 1982 rates, drawdown in the vicinity of the Vitro site in the year 2020 would be less than $20 \mathrm{ft}$ below 1982 levels. This suggests that regional drawdown is likely to be small. Locally, the effects of pumping from a well in the confined aquifer could cause a cone of depression to develop and could lead to reversal of gradient and potential migration of contaminants from the shallow aquifer into the confined aquifer. However, due to the thickness of the confining layer and the depth at which water supply wells are screened in the vicinity of the Vitro site it is unlikely that any contaminants would ever be detected in discharge from such a well due to dispersion and dilution.

\subsection{BACKGROUND GROUND WATER QUALITY SUMMARY}

Background water quality for the Vitro site is defined as the water quality if uranium milling activities had not occurred. The deep confined aquifer is the principal aquifer in the Salt Lake Basin (Seiler and Waddell, 1984). The shallow, unconfined aquifer is seldom used as a source of water for domestic or industrial purposes because of its ease of contamination, thus generally yielding water of poor quality (Seiler and Waddell, 1984).

Water quality is different in various areas of the Salt Lake Valley area. For example, along the Wasatch Front, ground water quality reflects that of mountain stream recharge, while near the Great Salt Lake, ground water quality is saline, reflecting the influence of the lake and salt deposits. For the purposes of this report, the Central Valley area is defined as an area along the Jordan River extending about 5 miles $(8 \mathrm{~km})$ south of the site, 2 miles $(3.2 \mathrm{~km})$ north of the site, and about 2 miles $(3.2 \mathrm{~km})$ east and west of the Jordan River. This area is - representative of ground water quality reasonably expected in the area of the former Vitro site, based on regional studies of water quality throughout the valley (Thiros, 1995; Waddell et al., 1987; Seiler and Waddell, 1984).

\subsubsection{Confined aquifer water quality}

None of the DOE monitor wells in the confined aquifer (principal aquifer in the area) are designated as background because of possible historical variations in the local ground water flow related to pumpage of water supply wells in the region. This would include pumpage from the deep wells that provided process water for the Vitro uranium mill during its operation. Total dissolved solids (TDS) concentrations in the confined aquifer range from 251 to $1400 \mathrm{mg} / \mathrm{L}$ (DOE, 1995). The more saline water is found in monitor well 005 , on the west side of the site. This well has the highest sulfate and chloride levels of the four confined aquifer monitor 
wells. Historical data from DOE well 015 also show higher sulfate, chloride, and TDS levels in the area west of the site within the confined aquifer.

Previous studies (Waddell et al., 1987) have suggested that the TDS, chloride, sulfate, and iron levels in the confined aquifer west of the site are site related. This conclusion was based upon comparison of water quality west of the site (well 015) to water quality in wells north, southeast, and east of the site (001,002, and 003). Such a comparison (Table 3.1) indicates that the concentrations of major elements are greater in the western well. Nonetheless, levels of major elements and TDS observed in monitor wells west of the site are similar to levels reported for public water-supply wells completed in the confined aquifer west of the Jordan River (Table 3.1). Also, levels of uranium, a site-related contaminant, in ground water from monitor wells west of the site are low $(0.003 \mathrm{mg} / \mathrm{L}$ or less $)$. In general, uranium is a sensitive site indicator of ground water contamination, and levels observed in the confined aquifer to the west do not reflect site-related contamination.

The higher levels of major elements in the samples from DOE wells completed in the confined aquifer west of the site reflect natural ground water quality west of the Jordan River; pumpage of both the Vitro wells and City of South Salt Lake municipal wells east of the river may have drawn ground water west of the Jordan River toward the site.

Ground water from the DOE wells completed in the confined aquifer north, southeast, and east of the site is notable in that it contains little or no sulfate. This has been reported of ground water from the confined aquifer. The low concentrations may be the result of sulfate reduction in finer grained, confined layers (Thiros, 1995). This agrees with well logs and regional mapping of the thickness of the confining layer near the site, which indicate a thicker, more well developed confining zone east of the site when compared to the west. Thus, ground water in DOE wells north, southeast, and east of the site probably differ from those to the west not because of site-related contamination, but rather because of natural variations in lithology and geochemical conditions. Thus, there are no site-related impacts to the principal aquifer in the vicinity of the Vitro site.

\subsubsection{Background water quality in the shallow unconfined aquifer}

\section{Regional background quality}

Regional data for the shallow, unconfined aquifer indicate that water quality is variable, primarily because of the influence of activities at the land surface (Thiros, 1995). Natural processes of evapotranspiration are documented to affect its water quality (Thiros, 1995). Also, it is contaminated because of its proximity to the land surface. Sources of ambient contamination include historical landfills, lead smelters, cement kilns, chemical plants, and other active and inactive industrial sites spread throughout the valley. 
Table 3.1 Comparison of ground water quality in the confined aquifer at the Vitro site to water quality in public supply wells west of the Jordan River

\begin{tabular}{|c|c|c|c|c|c|}
\hline Well ID & $\begin{array}{c}\text { DOE well SLC-01- } \\
002\end{array}$ & $\begin{array}{l}\text { DOE well } \\
\text { SLC-01- } 015\end{array}$ & $\begin{array}{c}\text { DOE well } \\
\text { SLC-01- } \\
005\end{array}$ & $\begin{array}{l}(C-1-1) \\
23 c a a-1\end{array}$ & $\begin{array}{l}\text { (C-1-1) } \\
\text { 33ddd-1 }\end{array}$ \\
\hline Location & East side of site & West of site & $\begin{array}{c}\text { West side } \\
\text { of site }\end{array}$ & $\begin{array}{c}\text { Public supply } \\
\text { well, west of } \\
\text { Jordan River, } \\
\text { northwest of site } \\
\end{array}$ & $\begin{array}{l}\text { Public supply well, } \\
\text { west of Jordan } \\
\text { River, southwest } \\
\text { of site }\end{array}$ \\
\hline Date sampled & $8 / 31 / 90$ & $8 / 23 / 83$ & $8 / 31 / 90$ & $8 / 19 / 83$ & $8 / 6 / 92$ \\
\hline Alkalinity & 282 & 200 & 200 & 170 & 149 \\
\hline Chloride & 8 & 270 & 207 & 250 & 280 \\
\hline Calcium & 40 & 180 & 122 & 150 & 76 \\
\hline Fluoride & 0.3 & NA & 0.2 & 0.2 & 0.4 \\
\hline Magnesium & 20 & 79 & 60 & 83 & 51 \\
\hline $\mathrm{pH}$ & 7.6 & 7.4 & 7.4 & 7.6 & 7.6 \\
\hline Potassium & 11 & 18 & 17 & 13 & 6 \\
\hline Sodium & 35 & 43 & 36 & 56 & 160 \\
\hline Silica & 30 & NA & 36 & 15 & 49 \\
\hline Sulfate & $<0.1$ & 390 & 230 & 340 & 250 \\
\hline Uranium & 0.0003 & $<0.003$ & $<0.000$ & NA & NA \\
\hline TDS & 308 & 1120 & 855 & 1010 & 969 \\
\hline
\end{tabular}

Notes:

1. Data for public supply wells from Thiros, 1995.

2. Data are for filtered samples. Units are $\mathrm{mg} / \mathrm{L}$ except for $\mathrm{pH}$ (standard units).

NA - Not analyzed.

Ground water in the unconfined aquifer is recharged by streams draining from the Wasatch Front, water diverted for irrigation from the Jordan River, upward leakage from the confined part of the principal aquifer, and infiltration from precipitation (Thiros, 1995, Seiler and Waddell, 1984). In the central portion of the valley, shallow ground water (less than $60 \mathrm{ft}[18 \mathrm{~m}]$ deep) tends to be a calciummagnesium/sulfate-chloride type (Thiros, 1995). TDS concentrations are in the range of about 600 to $1900 \mathrm{mg} / \mathrm{L}$. Water from somewhat deeper depths $(60$ to $100 \mathrm{ft}$ [18 to $30 \mathrm{~m}]$ ) and probably within the confining layer or upper portion of the confined layer (Thiros, 1995) tend to have lower TDS concentrations (400 to 700 $\mathrm{mg} / \mathrm{L}$ ), reflecting the influence of vertical leakage from the confined portion of the principal aquifer (Table 3.2).

Seiler and Waddell (1984) found that the greatest concentrations of trace elements in the unconfined aquifer were in water from wells near landfills or tailings areas. The greatest measured concentration of cadmium was $0.2 \mathrm{mg} / \mathrm{L}$, of mercury was $0.0001 \mathrm{mg} / \mathrm{L}$, of iron was $37 \mathrm{mg} / \mathrm{L}$, and of arsenic was $360 \mathrm{mg} / \mathrm{L}$. All of these concentrations exceed criteria of the U.S. Environmental Protection Agency (EPA) for a domestic water supply (Seiler and Waddell, 1984). Also, several hazardous organic constituents were found in wells near landfills and tailings, including benzene, phenol, 1,1-dichoroethane, trichloroethylene, and chloroethylene. 
Table 3.2 Comparison of ground water quality in the unconfined aquifer at the Vitro site to general water in the unconfined aquifer in the central Salt Lake Valley

\begin{tabular}{|c|c|c|c|c|}
\hline Well ID & $\begin{array}{c}\text { Range in } \\
\text { water quality of } \\
\text { the unconfined } \\
\text { squifer } \\
22-52 \mathrm{ft} \\
(7-16 \mathrm{~m}) \\
\end{array}$ & $\begin{array}{c}\text { Range in } \\
\text { water quality of } \\
\text { the unconfined } \\
\text { aquifer } \\
66-100 \mathrm{ft} \\
(20-30 \mathrm{~m})\end{array}$ & $\begin{array}{c}\text { Average water } \\
\text { quality in DOE } \\
\text { background well } \\
006 \text {, } \\
26-28 \mathrm{ft} \\
(7.9-8.5 \mathrm{~m})\end{array}$ & $\begin{array}{c}\text { Average water quality in } \\
\text { DOE background well } 007 \\
26-28 \mathrm{ft} \\
(7.9-8.5 \mathrm{~m})\end{array}$ \\
\hline Location & $\begin{array}{c}\text { Central Valley } \\
\text { region }\end{array}$ & $\begin{array}{c}\text { Central Valley } \\
\text { region }\end{array}$ & Southeast of site & East of site \\
\hline $\begin{array}{l}\text { Alkalinity } \\
\text { Arsenic }\end{array}$ & $\begin{array}{l}103-451 \\
<0.001-0.11\end{array}$ & $\begin{array}{l}280-343 \\
\text { NA }\end{array}$ & $\begin{array}{l}692 \\
0.094^{\prime \prime}\end{array}$ & $\begin{array}{l}432 \\
0.04\end{array}$ \\
\hline Chloride & $100-850$ & $21-92$ & 314 & 63 \\
\hline Calcium & $40-190$ & $22-110$ & 62 & 12 \\
\hline Fluoride & $0.2-3.1$ & NA & 0.4 & 0.7 \\
\hline Iron & $<0.003-37$ & NA & 0.15 & 90.11 \\
\hline Magnesium & $34-110$ & $27-41$ & 69 & 34 \\
\hline Manganese & $<0.003-0.4$ & NA & 0.38 & 0.033 \\
\hline $\mathrm{pH}$ & $6.3-7.9$ & NA & 7.5 & 8.01 \\
\hline Potassium & $9-38$ & 4-32 & 52 & 30 \\
\hline Silica & $14-44$ & NA & NA & 26 \\
\hline Sodium & $79-450$ & $47-71$ & 241 & 136 \\
\hline Sulfate & $92-910$ & $8-190$ & 100 & $<2$ \\
\hline Uranium & NA & NA & 0.003 & $<0.001$ \\
\hline TDS & $615-1890$ & $441-690$ & 1220 & 547 \\
\hline
\end{tabular}

Notes:

1. Data for Central Valley region from Thiros (1995) and Seiler and Waddell (1984).

2. DOE well data collected from 1990 through 1995.

3. Values are for filtered samples. Units are $\mathrm{mg} / \mathrm{L}$ except for $\mathrm{pH}$ (standard units).

NA - Not analyzed.

Of the hazardous trace metals studied by Seiler and Waddell, (1984), arsenic tended to be most widely dispersed in the shallow aquifer, occurring in over 90 percent of the wells sampled and analyzed. The average concentration for arsenic in wells sampled was $0.048 \mathrm{mg} / \mathrm{L}$, with a range of $<0.001$ to $360 \mathrm{mg} / \mathrm{L}$. Overall, the range of data suggests that elevated levels of arsenic, as a well as other trace metals, occur in localized areas throughout the valley. This likely reflects, in many cases, the influence of past industrial activities on the water quality within the shallow unconfined aquifer, though natural sources of arsenic may also affect water quality (Seiler and Waddell, 1984).

Landfills appear to have been one source of arsenic to the shallow aquifer. Others appear to be tailings and slag heaps associated with abandoned smelters in the valley. Thirty-seven former smelter sites have been identified in the Salt Lake Valley (D.W. Moore and Associates, 1992). Most were in operation near the turn of the century, but in many cases, the slag heaps and tailings are still present at the former sites. Most smelters processed lead ores, though copper, silver, and gold were also produced. 
Several of the old smelter sites were located near the Vitro site, including three smelters along Big Cottonwood Creek located south-southeast of the site. These three smelters (Morgan-Haunauer Smelter, Wasatch Silver Lead Works Smelter, and Horns Silver Smelter) were about 1.5 miles $(2.4 \mathrm{~km})$ upgradient of the Vitro Site. Another smelter, the Badger State Smelter Works, was located on the south side of Mill Creek, just one mile $(1.6 \mathrm{~km})$ east and upstream of the Vitro Site. As discussed in the following sections, arsenic and high concentrations of particulate lead occur in background ground waters at the Vitro processing site. Old smelters in the area may account for these constituents in ground water.

Ground water in the areas of the four smelters closest to, and upgradient of, the Vitro site has not been characterized. However, ground water in the shallow aquifer at several other smelter sites, generally located further upgradient from the Vitro site, has been characterized in reports prepared for the EPA. Table 3.3 summarizes the concentrations of constituents that have been reported at two of these sites. These concentrations of constituents are likely typical of those to be expected in association with the old smelters.

Trace metals found in ground water affected by the smelters include arsenic, cadmium, copper, lead, and selenium. Of these, arsenic has the highest concentrations (up to $28.9 \mathrm{mg} / \mathrm{L}$ ) and a widespread occurrence, as indicated by the frequency of detection in ground water near the old smelter sites. The arsenic exists as a dissolved anion in the ground water at the smelter sites. By contrast, lead more commonly occurs as a solid adsorbed onto suspended solids (fine-grained particles) in ground water, as indicated by the difference in frequency of detection of dissolved lead (analyzed in filtered samples) and total lead (analyzed in unfiltered samples; Table 3.3).

Airborne dusts from the old smelter slag heaps and dust from operating mines and smelters in the valley may be a source of contaminants to the shallow, unconfined aquifer. Results of state of Utah air quality monitoring in the Salt Lake Valley are presented in Table 3.4 .

Airbornes in the valley have normal concentrations (within a factor of three compared to normal soils) of vanadium, iron, manganese, chromium, and nickel. Concentrations of arsenic, zinc, lead, copper, molybdenum, and selenium are 17 to 186 times normal concentrations for soils. This likely reflects the influence of mining and smelters on dust composition in the valley. Airbornes affect sediment chemistry and surface water quality. Those effects on the surface water and sediment may also affect ground water quality in the shallow, unconfined aquifer.

Other documented impacts to the shallow unconfined aquifer occur crossgradient (north) and downgradient (northwest) of the Vitro site. These include inorganic contaminants in ground water (arsenic to $10.2 \mathrm{mg} / \mathrm{L}$, chromium to $0.132 \mathrm{mg} / \mathrm{L}$, molybdenum to $137 \mathrm{mg} / \mathrm{L}$, and lead to $0.071 \mathrm{mg} / \mathrm{L}$ ) at the Portland Cement Kiln Dust Superfund Site located about 3 miles $(5 \mathrm{~km})$ northwest of the Vitro processing site (URS Consultants, 1993). Inorganic contaminants detected in ground water at 
Table 3.3 Ground water quality in the shallow, unconfined aquifer associated with former smelters in the Salt Lake City Valley

\begin{tabular}{|c|c|c|c|c|c|c|}
\hline \multirow[t]{2}{*}{ Smelter site } & \multicolumn{3}{|c|}{ Murray Smelter } & \multicolumn{3}{|c|}{ Sharon Steel/Midvale tailings site } \\
\hline & $\begin{array}{l}\text { Minimum } \\
\text { mg/L }\end{array}$ & $\begin{array}{l}\text { Maximum } \\
\text { mg/L }\end{array}$ & $\begin{array}{c}\text { Frequency } \\
\text { of } \\
\text { detection }\end{array}$ & $\begin{array}{c}\text { Minimum } \\
\mathrm{mg} / \mathrm{l}\end{array}$ & $\begin{array}{l}\text { Maximum } \\
\mathrm{mg} / \mathrm{L}\end{array}$ & $\begin{array}{c}\text { Frequency } \\
\text { of } \\
\text { detection }\end{array}$ \\
\hline Depth $(\mathrm{ft})$ & 19 & 45 & NA & & & \\
\hline Arsenic & $<0.005$. & 28.9 & $16 / 20$ & $<0.01$ & 0.219 & $4 / 7$ \\
\hline Cadmium & $<0.0005$ & 0.134 & $5 / 20$ & $<0.003$ & 0.040 & $1 / 7$ \\
\hline Copper & $<0.005$ & 0.064 & $4 / 20$ & $<0.002$ & 0.035 & $6 / 7$ \\
\hline Lead & $<0.002$ - & 0.132 & $5 / 20$ & $<0.005$ & 0.008 & $1 / 7$ \\
\hline Lead (total) & $<0.002$ & 0.15 & $18 / 20$ & NA & NA & NA \\
\hline Manganese & 0.023 & 1.86 & $20 / 20$ & 0.014 & 1.54 & $7 / 7$ \\
\hline Nickel & $<0.04$ & 0.041 & $1 / 20$ & $<0.014$ & $<0.014$ & $0 / 7$ \\
\hline Selenium & $<0.005$ & 0.192 & $11 / 20$ & NA & NA & NA \\
\hline Silver & $<0.0003$ & 0.004 & $1 / 20$ & $<0.004$ & $<0.004$ & $0 / 7$ \\
\hline Thallium & $<0.01$ & $<0.01$ & $0 / 20$ & NA & NA & NA \\
\hline Zinc & $<0.02$ & 1.39 & $10 / 20$ & 0.013 & 8.52 & $7 / 7$ \\
\hline TDS & 539 & 3174 & $20 / 20$ & 610 & 2330 & $7 / 7$ \\
\hline Calcium & 71 & 320 & $20 / 20$ & 81 & 389 & $7 / 7$ \\
\hline Magnesium & 34 & 160 & $20 / 20$ & 28 & 94 & $7 / 7$ \\
\hline Sodium & 60 & 205 & $20 / 20$ & 77 & 229 & $7 / 7$ \\
\hline Potassium & 10 & 58 & $20 / 20$ & 5 & 25 & $7 \pi$ \\
\hline Sulfate & 52 & 1325 & $20 / 20$ & 160 & 1300 & $7 \pi$ \\
\hline Chloride & 47 & 381 & $20 / 20$ & 100 & 280 & $7 / 7$ \\
\hline $\mathrm{pH}$ & 6.98 & 7.55 & $20 / 20$ & 6.6 & 7.2 & $7 / 7$ \\
\hline Iron & 0.0 & 4.6 & $10 / 20$ & NA & NA & NA \\
\hline Sulfide & 0 & 1.5 & $4 / 20$ & NA & NA & NA \\
\hline
\end{tabular}

Notes:

1. Data from EPA, 1989, and Hydrometrics, Inc., 1995.

2. Values given are for filtered samples unless noted as total (unfiltered). Units in $\mathrm{mg} / \mathrm{L}$ except for $\mathrm{pH}$ (standard units).

NA $=$ Not analyzed.

TDS $=$ Total dissolved solids . 
Table 3.4 Comparison of the composition of Salt Lake Valley airbornes to average Western U.S. soils

\begin{tabular}{lccc}
\hline Average Western U.S. & $\begin{array}{c}\text { Salt Lake Valley } \\
\text { soil } \\
\text { in mg/kg }\end{array}$ & $\begin{array}{c}\text { Ratio airbornes } \\
\text { in mg/kg }\end{array}$ & $\begin{array}{c}\text { element to element } \\
\text { in average soil }\end{array}$ \\
\hline Element & 70 & 22 & 0.3 \\
Vanadium & 21,000 & 16,135 & 0.8 \\
Iron & 380 & 327 & 0.9 \\
Manganese & 41 & 53 & 1.3 \\
Chromium & 15 & 28 & 1.8 \\
Nickel & 5.5 & 92 & 16.8 \\
Arsenic & 55 & 1146 & 20.8 \\
Zinc & 17 & 609 & 35.8 \\
Lead & 21 & 952 & 45.3 \\
Copper & 0.85 & 69 & 81.7 \\
Molybdenum & 0.23 & 43 & 186.4 \\
Selenium & NA & 70 & NA \\
Silver & NA & 79 & NA \\
Cadmium & NA & 113 & NA \\
Antimony & & & \\
\hline
\end{tabular}

Notes:

1. Data for Western U.S. soils from Shacklette and Boerngen, 1984.

2. Data for Salt Lake Valley aerosols from Utah Division of Air Quality, 1995.

NA $=$ Not analyzed

the Wasatch Chemical Superfund Site, about 1.3 miles $(2 \mathrm{~km})$ north of the Vitro processing site (crossgradient), include arsenic (up to $0.194 \mathrm{mg} / \mathrm{L}$ ) and antimony (up to $0.086 \mathrm{mg} / \mathrm{L}$ ). In addition, several organic compounds were detected in ground water, including herbicides (Harding Lawson Associates, 1990).

\section{Background water quality at the Vitro processing site}

Based on results of Hydropunch ground water screening (see Attachment 1), background water quality in the confined aquifer varies with depth and the lithologic type. Splay deposits at depths of about 28 to $37 \mathrm{ft}(8.5$ to $11 \mathrm{~m}$ [HP-1, HP-14, HP15, and HP-16]) have low chloride concentrations and little or no detectable sulfate. This likely reflects recharge by vertical leakage from the confined aquifer, sulfate reduction related to organic matter in the floodplain deposits, and isolation from overlying sources of ground water recharge. By contrast, ground waters in the shallower channel sands have greater concentrations of chloride and sulfate, reflecting the influence of surface water on ground water in the shallow channel sands.

Background water quality for the shallow unconfined aquifer at the Vitro site has been established in two DOE monitor wells, 007 and 006 (Figure 3.1). Monitor well 007 is about $1000 \mathrm{ft}(300 \mathrm{~m})$ from the site and crossgradient (east) of the site. It is screened at 30 to $40 \mathrm{ft}(9$ to $12 \mathrm{~m}$ ) and is completed in a splay deposit (based on water quality). Monitor well 006 is located about $1000 \mathrm{ft}(300 \mathrm{~m})$ upgradient 
(southeast) of the site and is also screened at 30 to $40 \mathrm{ft}(9$ to $12 \mathrm{~m}$ ) below the surface. However, well 006 has greater TDS and sulfate concentrations when compared to well 007, and therefore, is thought to be completed in a channel deposit.

Water quality in samples collected from monitor well 006 is similar to that reported regionally from the shallow portion of the unconfined aquifer in the Central Valley area (Table 3.2). Concentrations of calcium, magnesium, sodium, chloride, and sulfate fall within reported ranges for these major elements in ground water of the shallow aquifer. Alkalinity is somewhat higher than is normal. This may be due to the influence of suspended solids on the alkalinity, determined in unfiltered samples. Uranium concentrations in the samples range from $<0.001$ to $0.004 \mathrm{mg} / \mathrm{L}$.

The Hydropunch screening of ground water determined that the water quality in well 006 is actually lower in sulfate than background ground water sampled at several other locations (HP-13, -14, -15, and -16). For example, sulfate in well 006 is about $160 \mathrm{mg} / \mathrm{L}$ compared to 280 to $4000 \mathrm{mg} / \mathrm{L}$ in background samples collected during screening. However, chloride concentrations in well 006 are similar to those at the other background locations, which range from 90 to 1320 $\mathrm{mg} / \mathrm{L}$. Thus, ground water in well 006 is typical of background in the shallow aquifer channel deposits except for somewhat lower sulfate concentrations, likely reflecting the influence of sulfate reduction.

Screening samples of ground water in shallow channel deposits at background locations HP-13, $-14,-15$, and -16 (Figure 3.1) determined that arsenic was present at all these locations at levels ranging from 0.009 to $0.029 \mathrm{mg} / \mathrm{L}$. Arsenic concentrations in well 006 range from 0.063 to $0.132 \mathrm{mg} / \mathrm{L}$ and exceed the UMTRA maximum concentration limits (MCL) (40 CFR Part 192) and the EPA primary drinking water standard. These values likely reflect the influence of smelting operations in the Salt Lake Valley. This is supported by concentrations of two other constituents (copper and lead) associated with smelting in ground water samples from well 006. The lead and copper are concentrated on filterable particulates sampled from well 006 . Dissolved concentrations are below the method detection limits. In the unfiltered samples, total lead ranges from 0.009 up to $1.08 \mathrm{mg} / \mathrm{L}$ and total copper ranges from $<0.02$ up to $0.88 \mathrm{mg} / \mathrm{L}$. The high variability reflects the variation in the amount of suspended particulates in the samples collected from well 006. Arsenic occurs primarily as a dissolved component, and its concentrations are less sensitive to levels of suspended solids.

Ground water quality in well 007 differs from that of well 006 . Concentrations of major elements and TDS are less (Table 3.2). Water quality in well 007 is similar to that reported regionally for the deeper portions of the unconfined aquifer, the portions that appear to be influenced more by vertical leakage from the confined aquifer coupled with sulfate reduction (Thiros, 1995). The influence of sulfate reduction is reflected in the low sulfate concentrations in ground water sampled from well 007 (generally less than $2 \mathrm{mg} / \mathrm{L}$ ). Uranium concentrations in this background well are generally less than $0.001 \mathrm{mg} / \mathrm{L}$. 
Screening sampling of background ground water in splay deposits at locations HP$13,-14,-15$, and -16 determined that arsenic was again present at these locations at levels ranging from 0.023 to $0.173 \mathrm{mg} / \mathrm{L}$. The Hydropunch screening of ground water quality also determined that the water quality in well 007 is typical of background in the unconfined aquifer splay deposits at 28 to $37 \mathrm{ft}(8.5$ to $11 \mathrm{~m})$ (see data for HP-13,-14, -15, and -16 in Attachment 1).

Arsenic also occurs in DOE monitoring well 007, at levels ranging from 0.021 up to $0.060 \mathrm{mg} / \mathrm{L}$. Copper has not been detected in either filtered or unfiltered samples collected from this well, and lead has only been detected at low levels $(0.003 \mathrm{mg} / \mathrm{L}$ ) in unfiltered samples. This reflects lower concentrations of suspended solids in samples collected from well 007 when compared to those collected in well 006.

Table 3.5 provides a statistical summary of water quality data for monitor wells 006 and 007 (background).

\subsection{MAGNITUDE AND EXTENT OF CONTAMINATION}

The original tailings solution within tailings piles and evaporation ponds was an acid solution ( $\mathrm{pH}$ less than 4) composed predominantly of aluminum and magnesium sulfate (Markos and Bush, 1983). Previous geochemical studies demonstrated that, as the solutions migrated into the unconfined aquifer, they were immediately neutralized at the tailings-soil interface by the reaction of calcite and dolomite with the acid solution. This produced a thin zone of precipitates at the interface. This 4-inch (10-centimeter) zone, including gypsum, iron oxides, basic iron, and aluminum sulfates (Markos and Bush, 1983), was removed along with other residual radioactive materials during surface remediation of the site.

As a result of neutralization, precipitation, and pH-dependent sorption, contaminated ground water within the unconfined aquifer contains relatively low concentrations of heavy metals and metalloids. Contamination is primarily recognized by high concentrations of TDS and major ions including sulfate, chloride, calcium, magnesium, and sodium and by elevated concentrations of uranium.

Site-related constituents in ground water at the site have been identified as ammonium, barium, calcium, chloride, fluoride, iron, magnesium, manganese, molybdenum, potassium, silver, sodium, strontium, sulfate, uranium, and radium226 (DOE, 1995). Of these, constituents having the greatest contrast in the contaminated area compared to background (greater than 50 times background) are molybdenum, sulfate, and uranium. These are the most sensitive indicators of ground water contamination. Calcium, chloride, iron, magnesium, potassium, sodium, and strontium levels are closer to background (between 4 and 14 times background concentrations). Ammonium, fluoride, manganese, silver, and radium226 are only slightly elevated above background and are poor indicators of siterelated contamination of ground water.

Hydraulic gradients prevent migration of contaminants east and south of the site. On-site and to the west of the site, concentrations of site-related constituents vary 
Table 3.5 Summary of ground water quality data in the shallow unconfined aquifer at Salt Lake City, Utah, 1990 -1995

\begin{tabular}{llllll}
\hline & \multirow{2}{*}{$\begin{array}{c}\text { Detection } \\
\text { Parameter }\end{array}$} & \multicolumn{3}{c}{ Concentration $^{\mathrm{b}}$} \\
\cline { 5 - 6 } & frequency $^{\mathrm{c}}$ & Minimum & Median & Maximum \\
\hline Alkalinity as $\mathrm{mg} / \mathrm{L} \mathrm{CaCO}_{3}{ }^{\mathrm{d}}$ & & & & \\
Background (006) & $5 / 5$ & 537 & 670 & 890 \\
Background (007) & $11 / 11$ & 298 & 445 & 495 \\
Site-affected wells & $65 / 65$ & 263 & 478 & 1178 \\
Well 135 & $3 / 3$ & 1070 & 1088 & 1178
\end{tabular}

Aluminum

$\begin{array}{lllrr}\text { Background (006) } & 0 / 1 & - & <0.05 & - \\ \text { Background (007) } & 1 / 6 & <0.05 & <0.05 & <0.05 \\ \text { Site-affected wells } & 10 / 40 & <0.05 & <0.05 & 0.14 \\ \text { Well } 135 & 2 / 3 & <0.05 & 0.05 & 0.14\end{array}$

Ammonium

Background (006)

Background (007)

$4 / 4$

$9 / 9$

Site-affected wells

Well 008

Antimony

Background (006)

Background (007)

Site-affected wells

Well 135

Arsenic

Background (006)

Background (007)

Site-affected wells

Well 131

$59 / 59$

$9 / 9$

NA

$1 / 6$

$14 / 33$

$1 / 3$

$4 / 4$

$10 / 10$

$49 / 58$

$6 / 6$

\section{7}

6

0.45

6.6

31

9

8.6

11

56

12

20.9

20.9

$<0.003$
$<0.003$
$<0.01$

$<0.003$

$<0.003$

$<0.015$

0.063

0.021

0.090

0.035

0.06

$<0.005$

0.028

0.047

0.079

Arsenic (total)

Background (006)

Background (007)

$3 / 3$

$3 / 3$

Site-affected wells

$25 / 28$

Well 131

$3 / 3$

0.025

0.027

0.027

\section{Barium $^{d}$}

Background (006)

Background (007)

$1 / 2$

$8 / 8$

0.132

0.145

0.145

Site-affected wells

$34 / 51$

0.110

0.150

0.289

0.021

0.030

0.031

$<0.005$

0.050

0.140

0.070

0.116

0.140

Well 134

$<0.1$

0.10

$<0.01$

0.30
$<0.15$

0.12

0.18

0.47
0.15

0.12

0.61

0.61 
Table 3.5 Summary of ground water quality data in the shallow unconfined aquifer at Salt Lake City, Utah, 1990 -1995 (Continued)

\begin{tabular}{|c|c|c|c|c|}
\hline \multirow[b]{2}{*}{ Parameter $^{6}$} & \multirow{2}{*}{$\begin{array}{l}\text { Detection } \\
\text { frequency }\end{array}$} & \multicolumn{3}{|c|}{ Concentration ${ }^{a}$} \\
\hline & & Minimum & Median & Maximum \\
\hline \multicolumn{5}{|l|}{ Beryllium } \\
\hline Background (006) & NA & - & - & - \\
\hline Background (007) & $0 / 5$ & $<0.0012$ & $<0.005$ & $<0.005$ \\
\hline Site-affected wells & $0 / 26$ & $<0.0012$ & $<0.005$ & $<0.01$ \\
\hline Not detected & - & - & - & - \\
\hline \multicolumn{5}{|l|}{ Cadmium } \\
\hline Background (006) & $0 / 1$ & - & $<0.001$ & - \\
\hline Background (007) & $0 / 7$ & $<0.0005$ & $<0.001$ & $<0.001$ \\
\hline Site-affected wells & $1 / 39$ & $<0.0005$ & $<0.001$ & 0.001 \\
\hline Well 131 & $1 / 3$ & $<0.001$ & $<0.001$ & 0.001 \\
\hline \multicolumn{5}{|l|}{ Calcium $^{\text {d }}$} \\
\hline Background (006) & $4 / 4$ & 47 & 62 & 76 \\
\hline Background (007) & $10 / 10$ & 11 & 12 & 13 \\
\hline Site-affected wells & $66 / 66$ & 22 & 81 & 426 \\
\hline Well 008 & $9 / 9$ & 29 & 266 & 426 \\
\hline \multicolumn{5}{|l|}{ Chloride $^{d}$} \\
\hline Background (006) & $4 / 4$ & 296 & 310 & 342 \\
\hline Background (007) & $10 / 10$ & 56 & 62 & 74 \\
\hline Site-affected wells & $66 / 66$ & 10 & 423 & 2830 \\
\hline Well 135 & $3 / 3$ & 2580 & 2780 & 2830 \\
\hline \multicolumn{5}{|l|}{ Chromium } \\
\hline Background (006) & $0 / 1$ & - & $<0.01$ & - \\
\hline Background (007) & $0 / 6$ & $<0.003$ & $<0.01$ & $<0.01$ \\
\hline Site-affected wells & $0 / 33$ & $<0.003$ & $<0.01$ & $<0.02$ \\
\hline Not detected & - & - & - & - \\
\hline \multicolumn{5}{|l|}{ Chromium (total) } \\
\hline Background (006) & $1 / 1$ & - & 0.03 & - \\
\hline Background (007) & $0 / 1$ & - & $<0.01$ & - \\
\hline Site-affected wells & $1 / 7$ & $<0.01$ & $<0.01$ & 0.01 \\
\hline Well 008 & $1 / 1$ & - & 0.01 & - \\
\hline \multicolumn{5}{|l|}{ Cobalt } \\
\hline Background (006) & NA & - & - & - \\
\hline Background (007) & $0 / 5$ & $<0.03$ & $<0.03$ & $<0.05$ \\
\hline Site-affected wells & $0 / 26$ & $<0.004$ & $<0.05$ & $<0.10$ \\
\hline Not detected onsite & - & - & - & - \\
\hline
\end{tabular}


Table 3.5 Summary of ground water quality data in the shallow unconfined aquifer at Salt Lake City, Utah, 1990 -1995 (Continued)

\begin{tabular}{|c|c|c|c|c|}
\hline \multirow{2}{*}{ Parameter } & \multirow{2}{*}{$\begin{array}{l}\text { Detection } \\
\text { frequency }\end{array}$} & \multicolumn{3}{|c|}{ Concentration } \\
\hline & & Minimum & Median & Maximum \\
\hline \multicolumn{5}{|l|}{ Copper } \\
\hline Background (006) & $0 / 2$ & $<0.02$ & $<0.02$ & $<0.02$ \\
\hline Background (007) & $1 / 7$ & 0.003 & $<0.02$ & $<0.02$ \\
\hline Site-affected wells & $4 / 43$ & $<0.01$ & $<0.02$ & 0.37 \\
\hline Well 136 & $1 / 3$ & $<0.02$ & $<0.02$ & 0.37 \\
\hline \multicolumn{5}{|l|}{ Copper (total) } \\
\hline Background (006) & $2 / 3$ & $<0.02$ & 0.22 & 0.88 \\
\hline Background (007) & $0 / 3$ & $<0.02$ & $<0.02$ & $<0.02$ \\
\hline Site-affected wells & $2 / 27$ & $<0.02$ & $<0.02$ & 0.60 \\
\hline Well 136 & $1 / 3$ & $<0.02$ & $<0.02$ & 0.60 \\
\hline \multicolumn{5}{|l|}{ Cyanide } \\
\hline Background (006) & NA & - & - & - \\
\hline Background (007) & $0 / 4$ & $<0.01$ & $<0.01$ & $<0.01$ \\
\hline Site-affected wells & $0 / 17$ & $<0.01$ & $<0.01$ & $<0.01$ \\
\hline Not detected onsite & - & - & - & - \\
\hline \multicolumn{5}{|l|}{ Fluoride $^{d}$} \\
\hline Background (006) & $3 / 3$ & 0.4 & 0.4 & 0.4 \\
\hline Background (007) & $8 / 8$ & 0.6 & 0.7 & 0.9 \\
\hline Site-affected wells & $50 / 50$ & 0.4 & 0.9 & 2.8 \\
\hline Well 136 & $3 / 3$ & 1.7 & 1.7 & 2.8 \\
\hline \multicolumn{5}{|l|}{ Irond } \\
\hline Background (006) & $4 / 4$ & 0.07 & 0.15 & 0.21 \\
\hline Background (007) & $10 / 10$ & 0.04 & 0.08 & 0.25 \\
\hline Site-affected wells & $65 / 66$ & $<0.03$ & 1.40 & 6.78 \\
\hline Wëll 008 & $9 / 9$ & 0.13 & 2.22 & 6.78 \\
\hline \multicolumn{5}{|l|}{ Iron (total) } \\
\hline Background (006) & $3 / 3$ & 2.04 & 48 & 212 \\
\hline Background (007) & $4 / 4$ & 0.33 & 0.57 & 0.90 \\
\hline Site-affected wells & $33 / 34$ & $<0.03$ & 2.26 & 13.9 \\
\hline Well 008 & $4 / 4$ & 7.6 & 8.9 & 13.9 \\
\hline \multicolumn{5}{|l|}{ Lead } \\
\hline Background (006) & $0 / 4$ & $<0.003$ & $<0.003$ & $<0.003$ \\
\hline Background (007) & $0 / 7$ & $<0.002$ & $<0.003$ & $<0.005$ \\
\hline Site-affected wells & $3 / 59$ & $<0.003$ & $<0.003$ & 0.009 \\
\hline Well 008 & $1 / 8$ & $<0.003$ & $<0.005$ & 0.009 \\
\hline
\end{tabular}


Table 3.5 Summary of ground water quality data in the shallow unconfined aquifer at Salt Lake City, Utah, 1990 -1995 (Continued)

\begin{tabular}{|c|c|c|c|c|}
\hline \multirow[b]{2}{*}{ Parameter $^{\mathbf{b}}$} & \multirow{2}{*}{$\begin{array}{l}\text { Detection } \\
\text { frequency }\end{array}$} & \multicolumn{3}{|c|}{ Concentration ${ }^{\circ}$} \\
\hline & & Minimum & Median & Maximum \\
\hline \multicolumn{5}{|l|}{ Lead (total) } \\
\hline Background (006) & $3 / 3$ & 0.009 & 0.55 & 1.08 \\
\hline Background (007) & $1 / 3$ & $<0.003$ & $<0.003$ & 0.003 \\
\hline Site-affected wells & $6 / 27$ & $<0.003$ & $<0.003$ & 0.022 \\
\hline Well 130 & $1 / 3$ & $<0.003$ & $<0.003$ & 0.022 \\
\hline \multicolumn{5}{|l|}{ Magnesium ${ }^{\mathrm{d}}$} \\
\hline Background (006) & $4 / 4$ & 61 & 70 & 75 \\
\hline Background (007) & $10 / 10$ & 32 & 33 & 36 \\
\hline Site-affected wells & $66 / 66$ & 34 & 128 & 900 \\
\hline Well 135 & $3 / 3$ & 757 & 846 & 900 \\
\hline \multicolumn{5}{|l|}{ Manganese ${ }^{d}$} \\
\hline Background (006) & $4 / 4$ & 0.27 & 0.36 & 0.53 \\
\hline Background (007) & $10 / 10$ & 0.03 & 0.03 & 0.04 \\
\hline Site-affected wells & $66 / 66$ & 0.03 & 0.19 & 0.63 \\
\hline Well 109 & $5 / 5$ & 0.11 & 0.45 & 0.63 \\
\hline \multicolumn{5}{|l|}{ Mercury } \\
\hline Background (006) & NA & - & - & - \\
\hline Background (007) & $0 / 4$ & $<0.0001$ & $<0.0002$ & $<0.0002$ \\
\hline Site-affected wells & $1 / 26$ & $<0.0001$ & $<0.0002$ & 0.0002 \\
\hline Well 011 & $1 / 5$ & $<0.0002$ & $<0.0002$ & 0.0002 \\
\hline \multicolumn{5}{|l|}{ Molybdenum ${ }^{d}$} \\
\hline Background (006) & $0 / 4$ & $<0.01$ & $<0.01$ & $<0.01$ \\
\hline Background (007) & $1 / 10$ & $<0.01$ & $<0.01$ & 0.01 \\
\hline Site-affected wells & $43 / 66$ & $<0.01$ & 0.045 & 1.39 \\
\hline Well 131 & $4 / 4$ & 0.88 & 0.91 & 1.39 \\
\hline \multicolumn{5}{|l|}{ Molybdenum (total) ${ }^{d}$} \\
\hline Background (006) & $1 / 2$ & $<0.01$ & $<0.02$ & 0.02 \\
\hline Background (007) & $1 / 5$ & 0.007 & $<0.04$ & $<0.04$ \\
\hline Site-affected wells & $14 / 20$ & $<0.01$ & 0.01 & 1.02 \\
\hline Well 131 & $2 / 2$ & 0.31 & 0.67 & 1.02 \\
\hline \multicolumn{5}{|l|}{ Nickel } \\
\hline Background (006) & NA & - & - & - \\
\hline Background (007) & $1 / 5$ & 0.007 & $<0.04$ & $<0.04$ \\
\hline $\begin{array}{l}\text { Site-affected wells } \\
\text { Not detected onsite }\end{array}$ & $0 / 26$ & $<0.006$ & $<0.04$ & $<0.08$ \\
\hline
\end{tabular}


Table 3.5 Summary of ground water quality data in the shallow unconfined aquifer at Salt Lake City, Utah, 1990 -1995 (Continued)

\begin{tabular}{|c|c|c|c|c|}
\hline \multirow{2}{*}{ Parameter $^{b}$} & \multirow{2}{*}{$\begin{array}{l}\text { Detection } \\
\text { frequency }\end{array}$} & \multicolumn{3}{|c|}{ Concentration ${ }^{a}$} \\
\hline & & Minimum & Median & Maximum \\
\hline \multicolumn{5}{|l|}{ Nitrate } \\
\hline Background (006) & $1 / 1$ & - & 3 & - \\
\hline Background (007) & $5 / 6$ & $<1.0$ & 1.9 & 5.5 \\
\hline Site-affected wells & $12 / 32$ & $<1.0$ & $<1.0$ & 4.6 \\
\hline Well 008 & $3 / 5$ & $<1.0$ & 0.90 & 4.6 \\
\hline \multicolumn{5}{|l|}{$\mathrm{pH}$} \\
\hline Background (006) & $4 / 4$ & 7.1 & 7.8 & 7.8 \\
\hline Background (007) & $10 / 10$ & 7.9 & 8.1 & 8.2 \\
\hline Site-affected wells & $67 / 67$ & 5.71 & 7.36 & 8.01 \\
\hline Well 133 & $7 / 7$ & 5.71 & 7.61 & 7.84 \\
\hline \multicolumn{5}{|l|}{ Potassium ${ }^{d}$} \\
\hline Background (006) & $4 / 4$ & 47 & 51 & 59 \\
\hline Background (007) & $10 / 10$ & 26 & 31 & 35 \\
\hline Site-affected wells & $65 / 65$ & 17 & 42 & 274 \\
\hline Well 136 & $5 / 5$ & 176 & 200 & 274 \\
\hline \multicolumn{5}{|l|}{ Selenium } \\
\hline Background (006) & $0 / 1$ & - & $<0.005$ & - \\
\hline Background (007) & $0 / 7$ & $<0.001$ & $<0.005$ & $<0.005$ \\
\hline Site-affected wells & $3 / 39$ & $<0.002$ & $<0.005$ & 0.03 \\
\hline Well 109 & $1 / 5$ & $<0.002$ & $<0.005$ & 0.03 \\
\hline \multicolumn{5}{|l|}{ Silver ${ }^{d}$} \\
\hline Background (006) & $0 / 2$ & $<0.0002$ & $<0.0006$ & $<0.0006$ \\
\hline Background (007) & $0 / 7$ & $<0.0002$ & $<0.01$ & $<0.01$ \\
\hline Site-affected wells & $11 / 41$ & $<0.0002$ & $<0.01$ & 0.042 \\
\hline Well 135 & $1 / 2$ & $<0.02$ & - & 0.042 \\
\hline \multicolumn{5}{|l|}{ Silver (total) } \\
\hline Background (006) & $0 / 1$ & $\therefore$ & $<0.0006$ & - \\
\hline Background (007) & $0 / 1$ & - & $<0.0006$ & - \\
\hline $\begin{array}{l}\text { Site-affected wells } \\
\text { Not detected onsite }\end{array}$ & $0 / 11$ & $<0.0006$ & $<0.0006$ & $<0.0006$ \\
\hline \multicolumn{5}{|l|}{ Sodium ${ }^{d}$} \\
\hline Background (006) & $4 / 4$ & 230 & 244 & 248 \\
\hline Background (007) & $10 / 10$ & 129 & 136 & 150 \\
\hline Site-affected wells & $66 / 66$ & 23 & 332 & 3160 \\
\hline Well 135 & $4 / 4$ & 2710 & 3100 & 3160 \\
\hline
\end{tabular}


Table 3.5 Summary of ground water quality data in the shallow unconfined aquifer at Salt Lake City, Utah, 1990 -1995 (Continued)

\begin{tabular}{|c|c|c|c|c|}
\hline \multirow[b]{2}{*}{ Parameter $^{b}$} & \multirow{2}{*}{$\begin{array}{l}\text { Detection } \\
\text { frequency }\end{array}$} & \multicolumn{3}{|c|}{ Concentration $^{\circ}$} \\
\hline & & Minimum & Median & Maximum \\
\hline \multicolumn{5}{|l|}{ Strontium } \\
\hline Background (006) & $3 / 3$ & 0.52 & 0.57 & 0.80 \\
\hline Background (007) & $9 / 9$ & 0.20 & 0.21 & 0.55 \\
\hline Site-affected wells & $60 / 60$ & 0.21 & 1.39 & 5.58 \\
\hline Well 008 & $9 / 9$ & 0.8 & 3.64 & 5.58 \\
\hline
\end{tabular}

Sulfate ${ }^{d}$

Background (006)

Background (007)

Site-affected wells

Well 135

Sulfide

Background (006)

Background (007)

Site-affected. wells

Well 109

Thallium

Background (006)

Background (007)

Site-affected wells

Not detected

Tin

Background (006)

Background (007)

Site-affected wells

Not detected

Total Dissolved Solids ${ }^{d}$

Background (006)

Background (007)

Site-affected wells

Well 135

Uranium $^{\text {d }}$

Background (006)

Background (007)

Site-affected wells

Well 109

\section{$4 / 4$ \\ $5 / 9$ \\ $72 / 72$ \\ $5 / 5$}

NA

$3 / 5$

$4 / 26$

$1 / 5$

NA

$0 / 5$

$0 / 24$

-

\section{NA}

$1 / 5$

$0 / 26$

-

$\begin{array}{lr}3 / 3 & 1220 \\ 9 / 9 & 530 \\ 66 / 66 & 310 \\ 3 / 3 & 12,400\end{array}$

$3 / 4$

$1 / 10$

$50 / 66$

$5 / 5$

2,400

\section{6}

$<0.1$

$<1.0$

5100

$<1$

$<0.10$

$<0.10$

$<-0.005$

$<0.005$

$<0.01$

$<0.005$

$<0.07$

$<0.07$

\section{3}

2.1

2.1

$<1.0$

$<0.03$

$$
<0.005<0.005<0.10
$$

1220

1290

565

1825

14,500

14,500 
Table 3.5 Summary of ground water quality data in the shallow unconfined aquifer at Salt Lake City, Utah, 1990 -1995 (Continued)

\begin{tabular}{|c|c|c|c|c|}
\hline \multirow{2}{*}{ Parameter $^{b}$} & \multirow{2}{*}{$\begin{array}{l}\text { Detection } \\
\text { frequency }\end{array}$} & \multicolumn{3}{|c|}{ Concentration $^{2}$} \\
\hline & & Minimum & Median & Maximun \\
\hline \multicolumn{5}{|l|}{ Uranium (total) $^{\mathrm{d}}$} \\
\hline Background (006) & $2 / 2$ & 0.001 & 0.008 & 0.0 \\
\hline Background (007) & $0 / 3$ & $<0.001$ & $<0.001$ & $<0.001$ \\
\hline Site-affected wells & $23 / 28$ & $<0.001$ & 0.016 & 0.17 \\
\hline Well 139 & $2 / 2$ & 0.088 & 0.016 & 0.17 \\
\hline \multicolumn{5}{|l|}{ Vanadium $^{\mathbf{d}}$} \\
\hline Background (006) & $0 / 4$ & $<0.01$ & $<0.01$ & $<0.01$ \\
\hline Background (007) & $0 / 9$ & $<0.005$ & $<0.01$ & $<0.01$ \\
\hline Site-affected wells & $13 / 60$ & $<0.005$ & $<0.01$ & 0.17 \\
\hline Well 139 & $2 / 2$ & 0.12 & - & 0.17 \\
\hline \multicolumn{5}{|l|}{ Vanadium (total) $^{d}$} \\
\hline Background (006) & $1 / 2$ & $<0.01$ & $<0.36$ & 0.36 \\
\hline Background (007) & $0 / 3$ & $<0.01$ & $<0.01$ & $<0.01$ \\
\hline Site-affected wells & $4 / 27$ & $<0.01$ & $<0.01$ & 0.18 \\
\hline Well 139 & $2 / 2$ & 0.12 & - & 0.18 \\
\hline \multicolumn{5}{|l|}{ Zinc } \\
\hline Background (006) & NA & - & - & - \\
\hline Background (007) & $2 / 6$ & $<0.005$ & $<0.007$ & 0.018 \\
\hline Site-affected wells & $17 / 33$ & $<0.005$ & 0.015 & 0.187 \\
\hline Well 135 & $2 / 4$ & $<0.005$ & $<0.12$ & 0.187 \\
\hline
\end{tabular}

Radionuclide

Radium-226 ${ }^{\text {d }}$

Background (006)

$2 / 2$

0.3

0.35

0.4

$4 / 7$

0.0

0.3

0.5

Site-affected wells

$42 / 43$

0.0

0.40

1.30

Well 008

$7 / 7$

0.20

0.50

1.30

Radium-226 (total)

Background (006)

Background (007)

NA

$1 / 1$

Site-affected wells

$8 / 8$

$-$

Well 134

$1 / 1$

0.3

0.2

0.5

1.1

1.1

Radium-228

Background (006)

Background (007)

NA

Site-affected wells

$4 / 5$

$21 / 26$

-

-

Well 008

$4 / 5$

$-$

0.0

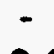

0.0

0.9

8.9

0.0

1.3

5.2

5.2

1.1 
Table 3.5 Summary of ground water quality data in the shallow unconfined aquifer at Salt Lake City, Utah, 1990 -1995 (Concluded)

\begin{tabular}{|c|c|c|c|c|}
\hline \multirow{2}{*}{ Parameter ${ }^{b}$} & \multirow{2}{*}{$\begin{array}{l}\text { Detection } \\
\text { frequency }\end{array}$} & \multicolumn{3}{|c|}{ Concentration $^{\circ}$} \\
\hline & & Minimum & Median & Maximum \\
\hline \multicolumn{5}{|l|}{ Polonium-210 (total) } \\
\hline Background (006) & NA & - & - & - \\
\hline Background (007) & $0 / 1$ & - & 0.0 & - \\
\hline Site-affected wells & $2 / 7$ & 0.0 & 0.0 & 0.10 \\
\hline Well 135 & $1 / 2$ & 0.0 & - & 0.10 \\
\hline \multicolumn{5}{|l|}{ Thorium-230 } \\
\hline Background (006) & NA & - & - & - \\
\hline Background (007) & $3 / 5$ & 0.0 & 0.2 & 0.94 \\
\hline Site-affected wells & $16 / 26$ & 0.0 & 0.25 & 1.40 \\
\hline Well 132 & $1 / 2$ & 0.0 & - & 1.4 \\
\hline \multicolumn{5}{|l|}{ Thorium-230 (total) } \\
\hline Background (006) & NA & - & - & - \\
\hline Background (007) & $0 / 1$ & - & 0.0 & - \\
\hline Site-affected wells & $7 / 7$ & 0.3 & 0.3 & 0.6 \\
\hline Well 008 & $1 / 1$ & - & 0.6 & - \\
\hline \multicolumn{5}{|l|}{ Lead-210 (total) } \\
\hline Background (006) & NA & - & - & - \\
\hline Background (007) & $1 / 1$ & - & 0.5 & - \\
\hline Site-affected wells & $5 / 7$ & 0.0 & 0.4 & 1.4 \\
\hline Well 133 & $1 / 1$ & - & 1.4 & - \\
\hline
\end{tabular}

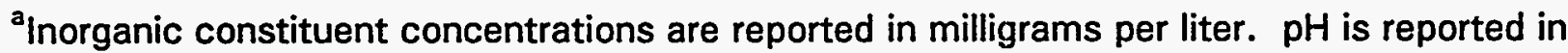
standard units. Radionuclide concentrations are reported in picocuries per liter.

bBackground wells are 006 and 007 . Site-affected wells are 008, 011, 109, 130, 131, $132,133,134,135,136,139,140$, and 141. Last well listed for each parameter is that well having the highest observed concentration of the site-affected wells.

'Number of samples with detected concentrations/total number of samples.

${ }^{d}$ Constituents are elevated in site-affected wells compared to background at the 0.05 level of significance. 
over time and area. Many of these variations likely reflect short-term changes in the local hydrology related to the history of surface activities that have occurred on or around the site, including surface remediation, development of properties around the perimeter, construction activities at the CVWRF, construction of a golf driving range, and maintenance and construction of storm sewers along the south and west boundaries of the site. These activities contribute to the complex distribution of site-related constituents.

Pumping of dewatering wells (and likely dewatering of subgrade foundations and leakage of ground water into sewer mains) at the CVWRF has created a ground water sink on site (Figure 3.2). As a result, contaminated ground water surrounding the site is being flushed toward the site.

Trends in water quality data from monitor wells west, northwest, and north of the site are likely the result of this flushing. In monitor wells immediately west of the site (011 and 109), concentrations of sulfate and chloride have steadily decreased since 1983. For example, in well 011 sulfate decreased from $7500 \mathrm{mg} / \mathrm{L}$ in 1983 to $1160 \mathrm{mg} / \mathrm{L}$ in 1992 (when the wells were abandoned), and uranium concentrations decreased from $0.14 \mathrm{mg} / \mathrm{L}$ to $0.044 \mathrm{mg} / \mathrm{L}$.

In well 134, located at the northwest corner of the site, concentrations of siterelated constituents abruptly decreased between July and December of 1995 . Prior to December of 1995 , sulfate concentrations were up to $505 \mathrm{mg} / \mathrm{L}$ while in December the sulfate was $91 \mathrm{mg} / \mathrm{L}$. Uranium concentrations also decreased from 0.06 to $0.019 \mathrm{mg} / \mathrm{L}$.

To the north of the site, in monitoring well 008, sulfate concentrations increased from $384 \mathrm{mg} / \mathrm{L}$ in 1990 to $2920 \mathrm{mg} / \mathrm{L}$ in 1995 . However, uranium concentrations in this well have remained low (less than $0.005 \mathrm{mg} / \mathrm{L}$ ). Thus, the increased sulfate may reflect migration of ambient ground water toward the site rather than siterelated contamination.

Chemical data from monitor wells on the south and east boundaries of the site (wells 130,132 , and 133) indicate that, prior to December 1994, contamination had not affected these crossgradient wells. These wells appear to have been completed in the deeper, hydrologically isolated, splay deposits. However, siterelated contaminants, including uranium and molybdenum, were detected in these wells beginning in December of 1994. These changes may be the result of nearsurface leakage of shallow ground water into the sand filter packs that extend up to within a few feet of the surface in these wells. These changes have been short term, and concentrations are returning to normal (background) at these locations. Arsenic concentrations have been elevated (up to $0.126 \mathrm{mg} / \mathrm{L}$ ) in all samples collected from these wells, including those collected prior to December of 1994. Thus, the arsenic is likely ambient.

In the southeast corner of the site, monitor well 131 has shown evidence of siterelated contamination. This well is near the old mill site, adjacent to the underpass of State Route 171 (3300 South Street) beneath the Southern Pacific Railway 
(Figure 3.1). There is a drain field at this underpass, and contaminated ground water in this area is discharged to the drainfield and then to a storm sewer and sump. The ground water is then pumped into a sewer that empties into the on-site South Vitro ditch. The underpass drainage system has created a local gradient reversal in the southeast corner of the site.

Two construction dewatering wells on the CVWRF site (wells 139 and 141) have sulfate and chloride concentrations similar to those in background ground water in the shallow channel deposits south of the site (HP-15 and -16). These wells appear to be pumping ambient (background) ground water from channel deposits. However, concentrations of molybdenum, uranium, and vanadium are relatively high (up to $0.43,0.17$, and $0.18 \mathrm{mg} / \mathrm{L}$, respectively), reflecting the influence of desorption of contaminants during the flushing of the aquifer. Based on two sampling rounds, levels of these metals are decreasing as pumping continues.

A Hydropunch sample collected from the deepest channel sand encountered on site (HP-12, sample 412) had $5000 \mathrm{mg} / \mathrm{L}$ of sulfate and a sulfate to chloride ratio of about 7. Molybdenum concentrations were relatively high $(0.09 \mathrm{mg} / \mathrm{L})$. The high sulfate concentration relative to chloride suggests that this ground water has a significant proportion of uranium processing solutions (which had median sulfate to chloride ratios of about 19 [Markos and Bush, 1983]). However, uranium concentrations were relatively low $(0.008 \mathrm{mg} / \mathrm{L})$. By contrast, ground water at the same location but in a shallower channel deposit, had the same uranium level $(0.008 \mathrm{mg} / \mathrm{L})$ but lower sulfate $(1200 \mathrm{mg} / \mathrm{L})$ and molybdenum $(0.03 \mathrm{mg} / \mathrm{L})$ and a ratio of sulfate to chloride similar to that in background (between 1 and 3). This suggests that the shallower ground water is being diluted by ambient ground water at this location.

Screening of shallow ground water off-site during March 1996, indicates that siterelated contamination is limited to areas close to the site. Sand deposits at four downgradient locations were sampled at shallow (about $12 \mathrm{ft}[3.7 \mathrm{ml}$ ) and deeper (27 to $38 \mathrm{ft}$ [8.2 to $12 \mathrm{~m}$ ]) depths using a Hydropunch. Two of the locations were adjacent to the Jordan River (Hydropunch locations HP-2 and HP-4). At both locations, the lithology indicated floodplain and splay deposits. The low permeability of these deposits inhibits ground water flow. Sulfate, chloride, and uranium concentrations (ranges of 500 to 580,390 to 505 , and 0.003 to 0.012 $\mathrm{mg} / \mathrm{L}$, respectively) are similar to those in the Jordan River upstream of the site. There is no clear evidence of site-related contamination in these deposits.

Channel sands were encountered at locations HP-6 and HP-10. HP-6 is westnorthwest of the site, between the site and Mill Creek. Shallow ground water at this location had relatively low concentrations of sulfate and chloride. Ground water levels at HP-6 indicate that there is a potential for this ground water to discharge to Mill Creek. Concentrations of molybdenum are low $(0.02 \mathrm{mg} / \mathrm{L})$ and similar to those in Mill Creek (about $0.01 \mathrm{mg} / \mathrm{L}$ ) and do not clearly indicate siterelated influences on water quality. At greater depth at the same location $121 \mathrm{ft}$ [6.4 m] and within the same channel deposit, concentrations of TDS, sulfate, and chloride are greater. But, the ratio of sulfate to chloride is again similar to that of 
background, molybdenum concentrations are lower than the detection limit 10.01 $\mathrm{mg} / \mathrm{L})$, and uranium concentrations are low $(0.004 \mathrm{mg} / \mathrm{L})$. Thus, it is likely that ground water at depth at location HP-6 is also ambient rather than site-related.

A channel sand encountered north of Mill Creek (HP-10) and northwest of the site is on the floodplain of the Jordan River. Water levels at this location are higher than those to the south along Mill Creek and higher than those at the northeast corner of the site. The potential for ground water flow at HP-10 is west-southwest, toward the confluence of the Jordan River and Mill Creek. Therefore, ground water flow from the site and from Mill Creek does not influence this location. Ground water levels at this location are within about $1 \mathrm{ft}(0.3 \mathrm{~m})$ of the surface of the floodplain, and evapotranspiration appears to have had an effect on ground water quality. At both sampled depths (11 and $27 \mathrm{ft} \mathrm{[3.3} \mathrm{and} 8.2 \mathrm{~m}$ ]), sulfate and chloride concentrations are elevated (about 2 to 3 times higher) relative to Mill Creek and the Jordan River. Molybdenum concentrations are below detection and uranium concentrations $(0.018 \mathrm{mg} / \mathrm{L})$ are similar to those in the Jordan River upstream of the site $(0.015 \mathrm{mg} / \mathrm{L})$, indicating no site-related influence on water quality. The relatively high sulfate and chloride concentrations at this location $11700 \mathrm{mg} / \mathrm{L}$ and $612 \mathrm{mg} / \mathrm{L}$, respectively) are likely due to evapotranspiration of ground water at the shallow water table at HP-10 or recharge of evaporatively concentrated surface water in low areas.

The conceptual model for the magnitude and extent of contamination is that contaminated ground water is currently being pumped from the site by CVWRF, and channel deposits in the shallow aquifer are being flushed by natural ground waters in response to this pumping. This pumping, in conjunction with natural ground water gradients (controlled by water levels in Mill Creek and the Jordan River) and the distribution of channel deposits, has limited the extent of contamination to the site and areas just west of the site, in the vicinity of former monitoring wells 011 and 109.

Trace metals (uranium, molybdenum, and vanadium) adsorbed onto the aquifer matrix are desorbing during flushing of the channel deposits. Flushing appears to be most rapid in the shallower portions of the channel sands. Deeper portions, for example at $28 \mathrm{ft}[8.5 \mathrm{~m}]$ in HP-12 on the site are less affected. However, in other areas, naturally high TDS water found near the base of some channel deposits is apparently flushing toward the site (monitor well 008). The depth of site-related contamination and ambient ground water having high TDS concentrations is limited by the depth of the channel sands (maximum depth of $35 \mathrm{ft}(11 \mathrm{~m})$ deposited by the Jordan River.

In the absence of dewatering at CVWRF, the Jordan River, located about $2000 \mathrm{ft}$ $(600 \mathrm{~m})$ west of the site, is the natural line of discharge for ground water in the shallow unconfined aquifer downgradient of the site (Lambert, 1995). Thus, the downgradient extent of contamination is limited to the west by the Jordan River. Based on regional modeling of ground water flow in the Salt Lake Valley (Lambert, 1995), ground water moving downgradient from the site should tend to flow in the 
direction of Mill Creek (west) toward its confluence with the Jordan River and discharge to the creek or river.

\subsection{SURFACE WATER RESULTS}

Except for a possible increase in uranium and molybdenum in Mill Creek attributable to site-related constituents in the treated sewage outfall, there appear to be no siterelated impacts due to contaminated ground water discharge to Mill Creek or the Jordan River. The levels of uranium and molybdenum in Mill Creek, due to the treated sewage discharge, are less than ambient levels of these constituents in the Jordan River.

\subsubsection{Mill Creek}

Mill Creek surface water has been sampled three times during 1994 and 1995. Sampling locations are upstream of the site (location 180), north (downgradient) of the site but upstream of CVWRF effluent discharge (locations 181 and 192), and downstream (and downgradient) of both the site and CVWRF discharge (location 182) (Figure 3.1). In addition, CVWRF effluent, which is a significant source of water to Mill Creek (about 53 gal [ $200 \mathrm{~L}$ ] per day), has been sampled (location 193). Results are shown in Table 3.6.

Surface water sampling of Mill Creek has detected no impacts of site-related constituents to Mill Creek water quality due to ground water discharge from the site. Decreases in calcium and sulfate and increases in sodium and chloride downstream of the site are attributable to CVWRF effluent discharge. The slight increase in uranium levels (from about $0.002 \mathrm{mg} / \mathrm{L}$ upstream to about $0.005 \mathrm{mg} / \mathrm{L}$ downstream) and molybdenum levels (from $<0.01$ to about $0.01 \mathrm{mg} / \mathrm{L}$ ) downstream of the site are also attributable to the CVWRF discharge.

It is possible that site-related ground water is affecting levels of uranium and molybdenum in the CVWRF discharge. Beginning in January 1995, contaminated ground water was pumped from the shallow unconfined aquifer by CVWRF. Three wells were pumped to locally dewater the aquifer during construction of CVWRF facilities. These wells pumped continuously at about 100 to 300 gal (380 to 1100 L) per minute, for a total pumpage of about 1 million gal ( 3.8 million $L$ ) per day, or less. The water has been added to the sewage treatment circuit. Measured uranium levels from two of the dewatering wells (wells 139 and 141) varied from 0.036 to $0.166 \mathrm{mg} / \mathrm{L}$. Molybdenum varied from 0.03 to $0.43 \mathrm{mg} / \mathrm{L}$. Assuming 1) the highest of these uranium and molybdenum concentrations, 2) an average discharge of 53 million gal (200 million $L$ ) of treated sewage, and 3 ) the addition of 1 million gal ( 3.8 million $L$ ) of contaminated ground water to the treated sewage, then increases in uranium and molybdenum concentrations in the treated sewage can be calculated. The calculated increases are approximately $0.003 \mathrm{mg} / \mathrm{L}$ for uranium, and $0.008 \mathrm{mg} / \mathrm{L}$ for molybdenum. This calculation demonstrates that the dewatering is a possible explanation of the observed levels of uranium and molybdenum in the treated effluent. 
Table 3.6 Surface water quality data for Mill Creek, Salt Lake City, Utah, site

\begin{tabular}{|c|c|c|c|c|c|}
\hline Constituent & $\begin{array}{c}\text { Upstream of } \\
\text { site } \\
180 \\
\end{array}$ & \multicolumn{2}{|c|}{ West of railroad tracks } & $\begin{array}{c}\text { Treated sewage } \\
\text { outfall } \\
193 \\
\end{array}$ & $\begin{array}{c}\text { Downstream of } \\
\text { treated sewage } \\
\text { outfall } \\
182 \\
\end{array}$ \\
\hline Alkalinity & 241 & NA & 196 & 196 & 198 \\
\hline Ammonium & 0.13 & NA & NA & NA & 7.9 \\
\hline Arsenic & $<0.005$ & NA & $<0.005$ & $<0.005$ & $<0.005$ \\
\hline Barium & $<0.1$ & NA & NA & NA & $<0.1$ \\
\hline Calcium & 102 & NA & 93 & 73 & 83 \\
\hline Chloride & 59 & 67 & 54 & 196 & 155 \\
\hline Copper & $<0.02$ & NA & $<0.02$ & $<0.02$ & $<0.02$ \\
\hline Copper (total) & $<0.02$ & NA & $<0.02$ & $<0.02$ & $<0.02$ \\
\hline Iron & $<0.03$ & NA & $<0.03$ & 0.04 & 0.04 \\
\hline Iron (total) & 0.26 & NA & 0.33 & 0.10 & 0.17 \\
\hline Lead & $<0.003$ & NA & $<0.003$ & $<0.003$ & $<0.003$ \\
\hline Lead (total) & $<0.003$ & NA & $<0.003$ & $<0.003$ & $<0.003$ \\
\hline Magnesium & 28 & 39 & 33 & 32 & 33 \\
\hline Manganese & 0.02 & NA & NA & NA & 0.03 \\
\hline Molybdenum & $<0.01$ & NA & $<0.01$ & $<0.01$ & $<0.01$ \\
\hline $\begin{array}{l}\text { Molybdenum } \\
\text { (total) }\end{array}$ & $<0.01$ & $<0.01$ & $<0.01$ & 0.01 & 0.01 \\
\hline $\mathrm{pH}$ & 8.03 & NA & 7.91 & 7.12 & 7.11 \\
\hline Potassium & 4.0 & NA & NA & NA & 21 \\
\hline Radium-226 & 0.1 & NA & NA & NA & 0.0 \\
\hline Selenium (total) & $<0.005$ & $<0.005$ & NA & NA & $<0.005$ \\
\hline Silver & $<0.0006$ & $<0.01$ & $<0.0006$ & $<0.0006$ & $<0.0006$ \\
\hline Silver (total) & $<0.0006$ & NA & $<0.0006$ & $<0.0006$ & 0.0005 \\
\hline Sodium & 35 & 39 & 33 & 158 & 118 \\
\hline Strontium & 1.1 & 1.1 & NA & NA & 0.94 \\
\hline Sulfate & 165 & 173 & 137 & 148 & 141 \\
\hline TDS & 729 & NA & NA & NA & 960 \\
\hline Uranium & 0.001 & 0.002 & 0.0015 & 0.005 & 0.005 \\
\hline Uranium (total) & 0.002 & NA & 0.0015 & 0.005 & 0.005 \\
\hline Vanadium & $<0.01$ & NA & $<0.01$ & $<0.01$ & $<0.01$ \\
\hline Vanadium (total) & $<0.01$ & NA & $<0.01$ & $<0.01$ & $<0.01$ \\
\hline
\end{tabular}

Notes:

1. All data in $\mathrm{mg} / \mathrm{L}$ except $\mathrm{pH}$ (standard units) and radium-226 (pCi/L).

2. Data are for filtered samples, except for those constituents noted as total.

NA - Not analyzed.

The observed levels of uranium and molybdenum in the effluent and Mill Creek are, however, well below criteria for the protection of aquatic life (DOE, 1995). Further, the observed levels of these constituents in the effluent and Mill Creek are less than or equal to ambient levels in the Jordan River. 


\subsubsection{Jordan River}

Water samples were collected from the Jordan River during December 1994. Locations are upstream and upgradient of the site (location 185), downgradient of the site and upstream of the confluence of the river with Mill Creek (locations 188 and 1841, and downstream of the confluence (location 183) (Figure 3.1). Data from these locations are in Table 3.7.

Table 3.7 Surface water quality data of Mill Creek and Jordan River, Salt Lake City, Utah, site

\begin{tabular}{lcccccc}
\hline & \multicolumn{4}{c}{ Jordan River } \\
\cline { 2 - 3 } \cline { 5 - 6 } & Contaminant & Upstream & & \multicolumn{3}{c}{ Downstream } \\
\cline { 2 - 3 } \cline { 5 - 6 } & 185 & & 188 & 184 & 183 \\
\hline Calcium & 135 & & 139 & 141 & 86 \\
Chloride & 278 & & 296 & 288 & 200 \\
Magnesium & 60 & & 63 & 64 & 35 \\
Molybdenum & 0.01 & & 0.01 & 0.01 & $<0.01$ \\
Selenium & $<0.005$ & & $<0.005$ & $<0.005$ & $<0.005$ \\
Silver & $<0.01$ & & $<0.01$ & $<0.01$ & $<0.01$ \\
Sodium & 181 & & 186 & 191 & 150 \\
Strontium & 1.25 & & 1.29 & 1.28 & 0.79 \\
Sulfate & 339 & & 349 & 340 & 147 \\
Uranium & 0.015 & & 0.015 & 0.015 & 0.005 \\
\hline
\end{tabular}

Notes:

1. Unfiltered water samples collected 6 December 1993.

2. All parameters reported in milligrams per liter.

3. Sampling locations 184,185 , and 188 are upstream of the site. Sampling location 183 is downstream.

Comparing surface water quality in the Jordan River upstream of the site to that downgradient of the site indicates that, during these two sampling events, there were no noticeable site-related impacts on Jordan River water quality.

Concentrations of all constituents are nearly the same upstream and downstream of the site, except for an improvement in water quality downstream of the confluence with Mill Creek.

Below the confluence of the Jordan River and Mill Creek, the water quality of the Jordan River is nearly identical to that of Mill Creek during the 1993 sampling event. This probably means that the sample was Mill Creek water that had not yet mixed with the Jordan River water within the Jordan River channel. However, water quality in Mill Creek upstream and downstream of the site is better than that in the Jordan River, and water quality in the Jordan River can be expected to show some improvement downstream of the site. 


\subsection{LAND-USE EVALUATION}

\subsection{CURRENT AND PROJECTED USES OF THE UPPERMOST AQUIFER}

As discussed later in this document, application for supplemental standards as a ground water compliance strategy at the Vitro site should ensure that current and reasonably projected uses of the affected ground water from the uppermost unconfined aquifer are preserved. In addition, this ground water strategy must protect public health and the environment from radiological and nonradiological hazards associated with historical uranium milling activities. Therefore, this section identifies existing and projected future uses of land and the shallow unconfined aquifer near the site. The identified current and reasonably projected future uses of ground water from the uppermost unconfined aquifer are then evaluated for the ground water's potential to adversely affect human health and the environment. Off-site upgradient/crossgradient (background), downgradient, and on-site land uses and associated shallow ground water uses are evaluated to assess whether the incremental contribution of site-related contamination degrades water quality to a point where it prevents use of the water for a current or projected purpose and whether any action would be necessary to protect this use.

The 128-ac (52-ha) processing site is in an urban area in the city of South Salt Lake. As the metropolitan area expanded, the area around the Vitro site changed from agricultural and limited residential use to commercial and industrial use. Projected uses are commercial and industrial.

\subsubsection{Off-site land and shallow ground water uses}

The CVWRF sewage treatment plant (on property adjacent to the central portion of the site) and the channel of Mill Creek are north of the site. Warehouses and Denver \& Rio Grande Western Railroad property are farther to the north. The railroad also occupies the land on the east side of the site. This property extends as far as interstate 15. A cement batch plant is at the southeastern corner of the site.

On the south, the site is bounded by 3300 South Street. The land across 3300 South Street is occupied mainly by car dealerships and junk car yards. A mixed residential and farming area, consisting of about 20 to 25 residences, is about 300 $\mathrm{ft}(90 \mathrm{~m})$ away from the site's southwestern corner, across 3300 South Street. These are the nearest residences to the Vitro site. Livestock is kept by some of these residents. There is a planned correction facility to be located south of the western portion of the site.

On the west, the site is bounded by 900 West Street. The Jordan River affects land-use patterns further west. This area includes light industry, warehouses, commercial developments, and vacant land, with about 10 residences on 1100 West Street. An apartment complex, a correction facility, and a recreation area associated with the Jordan River are the other developments in the region. 
A survey of ground water use in the area surrounding the former Vitro site was conducted using information from the Utah Division of Water Rights database (Point of Diversion Location Program) in March and April 1994 and December 1995. The area investigated is about 3 miles $(5 \mathrm{~km})$ downgradient and about 2 miles $(3 \mathrm{~km})$ upgradient or crossgradient of the site. Figure 4.1 shows the researched area .

Table 4.1 presents information on private ground water wells recorded by the Point of Diversion Location Program for the survey area. Because many ground water wells were drilled in the late 1800 s and early 1900 s and no field investigations have been conducted to confirm their present use, the data shown in Table 4.1 may overestimate the real number of active wells. Data shown in Table 4.1 indicate, however, that there is very little, if any, use of the unconfined (uppermost) aquifer within a 2- to 3-mile (3- to 5-km) radius of the site. The shallow unconfined aquifer is seldom used in the area for domestic (potable) purposes because the water is of poor quality (Seiler and Waddell, 1984; Hely et al., 1971).

About 1800 wells are reported in the database (Table 4.1) for the surveyed area, and 99 percent of them are completed at depths greater than $50 \mathrm{ft}(16 \mathrm{~m})$. These wells are screened in the confined aquifer (Hely et al., 1971; Lambert, 1995). As discussed in Section 2.4, the upward vertical hydraulic gradient between the confined and unconfined aquifers prevents downward water migration from the unconfined aquifer. The remaining 1 percent consist of 16 shallow wells, up to $50 \mathrm{ft}(16 \mathrm{~m})$ deep, which are believed to have been completed in the uppermost unconfined aquifer.

Only two shallow wells are west of the site (Table 4.1). These wells are in Section 22, Township 1 South, Range 1 West, and Section 27, Township 1 South, Range 1 West (Figure 4.1). Water rights were issued for their use as irrigation wells (Table 4.2). However, the two shallow wells, completed in 1929 and 1936, are west of the Jordan River. Because shallow ground water discharges into the Jordan River (Hely et al., 1971), their location prevents any site-affected ground water migration to these wells. A detailed examination of the state engineer's database and an intensive field investigation downgradient from the site to the Jordan River did not reveal any users of the shallow-unconfined aquifer ground water (DOE, 1995).

Fourteen shallow wells are located within about 2 miles $(3 \mathrm{~km})$ upgradient and crossgradient of the site and are used for domestic and agricultural purposes. These wells were drilled in early 1900 s (except for one crossgradient well drilled in 1979).

No new shallow well development is anticipated downgradient of the site in the future due to predominantly commercial and industrial use of the land and the availability of city and county water supply systems.

\subsubsection{On-site land and shallow ground water uses}

The entire Vitro site is owned by the CVWRF, except for a $25-\mathrm{ft}$ by $25-\mathrm{ft}$ (8-m by $8-\mathrm{m}$ ) strip of land surrounding the municipal water well and an easement, which is 
POSITION PAPER ON THE APPLICABULTY OF SUPPLENENTAL STANDARDS TO THE UPPERANST AOUIFER AT THE UMTRA PROJECT VITRO PROCESSING SITE, SALT LAKE CITY, UTAH

LAND-USE EVALUATION

Figure 4.1

Area of Water Use Survey Upgradient, Crossgradient, and Downgradient Salt Lake City, Utah, Site

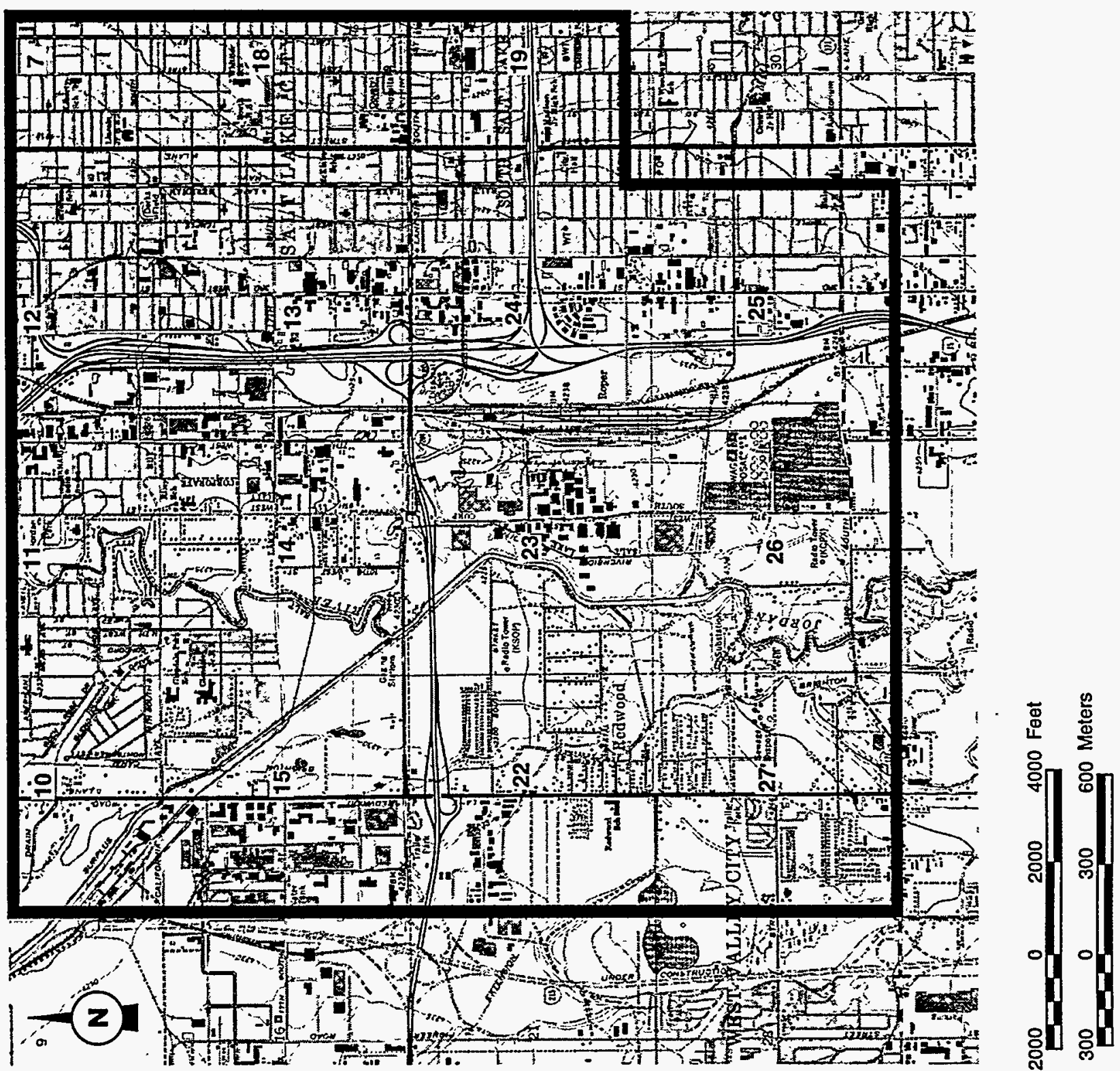


Table 4.1 Private ground water wells in the Vitro site area

\begin{tabular}{|c|c|c|c|}
\hline & \multicolumn{3}{|c|}{ Number of wells } \\
\hline & $50 \mathrm{ft}$ and less & $\begin{array}{c}51 \mathrm{ft} \text { and } \\
\text { deeper }\end{array}$ & Total number of wells \\
\hline Upgradient & 8 & 815 & 823 \\
\hline Crossgradient & 6 & 427 & 433 \\
\hline Downgradient & 2 & 530 & 532 \\
\hline $\begin{array}{l}\text { Total number } \\
\text { Percent }\end{array}$ & $\begin{array}{r}16 \\
1 \\
\end{array}$ & $\begin{array}{r}1772 \\
99 \\
\end{array}$ & $\begin{array}{r}1788 \\
100 \\
\end{array}$ \\
\hline
\end{tabular}

Table 4.2 Possible uses of shallow private wells upgradient, crossgradient, and downgradient of the site

\begin{tabular}{lcccc}
\hline $\begin{array}{c}\text { Ground water } \\
\text { uses }\end{array}$ & Upgradient wells & $\begin{array}{c}\text { Crossgradient } \\
\text { wells }\end{array}$ & Downgradient wells & Total wells \\
\hline Domestic & 0 & 0 & 0 & 0 \\
$\begin{array}{l}\text { Domestic and } \\
\text { agricultural }\end{array}$ & 8 & 4 & 0 & 12 \\
Agricultural & 0 & 2 & $2^{\mathrm{a}}$ & 4 \\
Total & 8 & 6 & $2^{\mathrm{a}}$ & 16 \\
\hline
\end{tabular}

${ }^{\circ}$ Both wells are west of the Jordan River from the site.

owned by the city of South Salt Lake. A 28-ac (11-ha) portion of the land in the southeast corner of the site has been leased and developed into a golf driving range. The city of South Salt Lake supplies irrigation water for about 25 ac (10 ha) of grass at the driving range. However, the treated water obtained from CVWRF may be used to irrigate the golf driving range in the future. Approximately 1 acrefoot of water is used for irrigation during the summer. About 0.2 to 0.9 inches 10.5 to $2.3 \mathrm{~cm}$ ) of water are applied to the driving range each month from May through September (DOE, 1995).

In 1985, the CVWRF sold the water rights to four on-site water supply wells to the city of South Salt Lake. These wells had been owned by the Vitro Uranium Company. Three wells have been abandoned. The remaining well, a 10-inch cased well, is in the southeast portion of the site. The city had planned to develop this well as a source for the municipal water supply system (DOE, 1995a). Current 
plans are to transfer the water rights to a off-site well and to abandon the on-site well (TAC, 1995).

The remaining on-site land is currently vacant but will probably be used for future expansion of the CVWRF. In the interim, the land may be leased for industrial, commercial, or recreational use.

\subsection{RISK-BASED EVALUATION OF CURRENT AND PROJECTED LAND USES}

This section evaluates whether current and projected future land uses and associated shallow ground water uses, downgradient off-site and on-site, are currently and will be protective of human health and environment. Off-site and onsite land uses and associated shallow ground water uses are evaluated separately.

\subsubsection{Risk-based evaluation of off-site land uses}

As discussed in previous sections, the site is in an urban area where commercial and industrial land use predominate. Based on the evaluation of the available information, it is anticipated that the land use near the site will not change substantially in the future. Therefore, this evaluation assumes current and projected future mixed commercial and industrial off-site land uses. This section evaluates both background and site-affected ground water to assess whether incremental contamination from the site would reduce already limited uses of the unconfined aquifer ground water any further.

\section{Human health concerns}

Currently, no one uses the uppermost unconfined aquifer ground water for any purpose downgradient of the site. Thus, no human health risks are associated with use of potentially site-affected shallow ground water downgradient of the site (see also DOE, 1995).

Because a few old shallow private wells are recorded for the areas upgradient and crossgradient of the site, this evaluation conservatively examines the possibility of using the uppermost unconfined aquifer for a drinking water source (Table 4.2). Due to their location, these shallow private wells have no potential to receive any site-affected shallow ground water. These wells might be completed in the areas where ambient non-site-related arsenic occurs in the unconfined aquifer (see Section 3.0). Therefore, this screening-level evaluation addresses the suitability of the off-site migrating site-affected shallow ground water as well as background (upgradient and crossgradient) ground water for drinking, using risk-based criteria or concentrations.

Table 4.3 compares concentrations of site-related constituents (DOE, 1995) and arsenic concentrations in background and off-site downgradient ground water of the unconfined aquifer to the no-observed-adverse-effect level (NOAEL) concentrations (benchmarks) developed for tap water (see Section 3.0 for definitions of background and off-site downgradient ground water). The results of this 


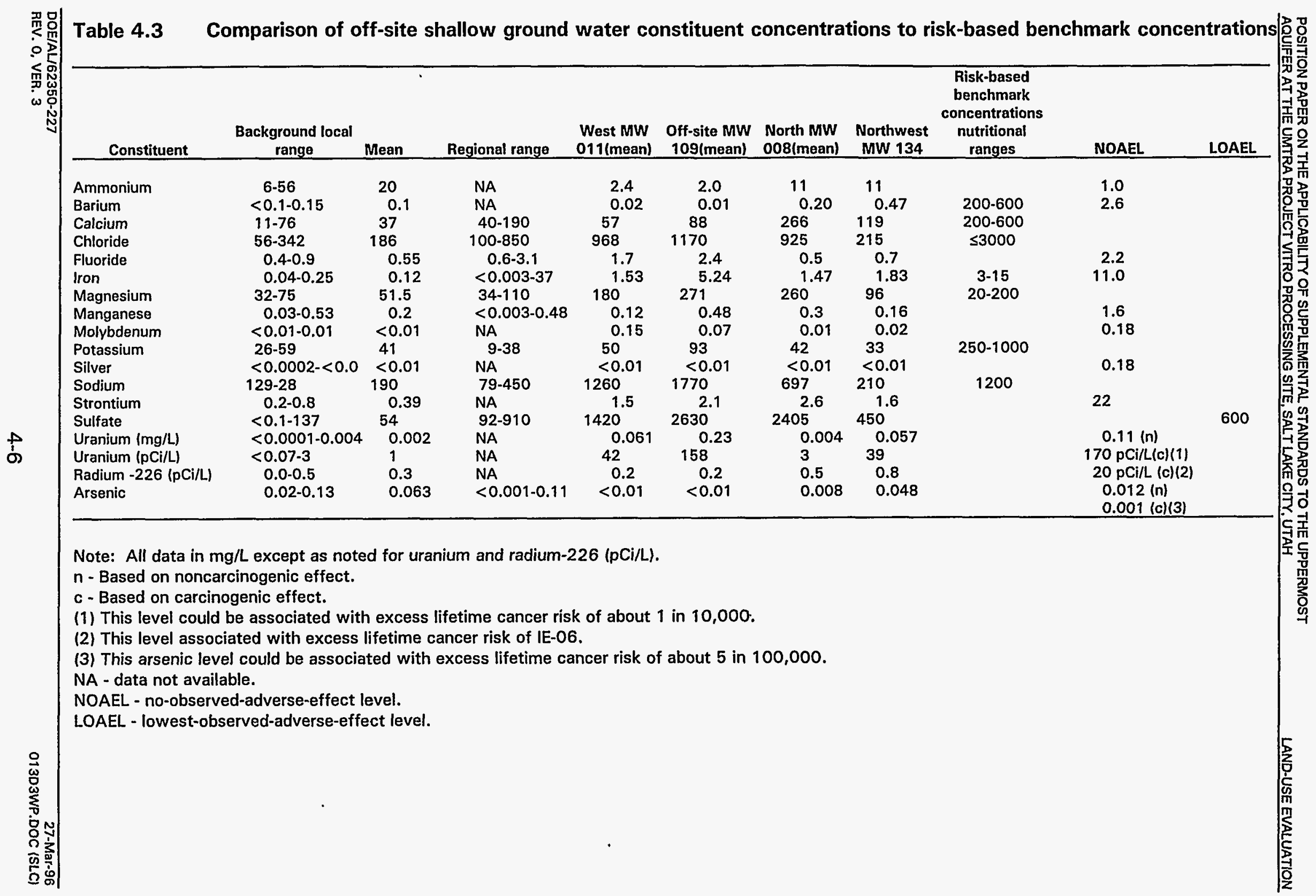


comparison are expected to be conservative because 1$)$ it is assumed that a person could drink 2 L of water a day; 2) NOAEL concentrations are based on the EPA oral reference dose, which usually incorporates a high safety factor (DOE, 1995); and 3) most NOAEL comparison benchmarks are based on oral reference doses (RfDs) established for long-term exposures.

This level of conservatism is needed to provide an upper bound on potential risks from unpredicted uses of the unconfined aquifer ground water in the future. Such uses may include future excavations that could result in transient surface exposure of the shallow ground water and that could lead to human contact with the water. Because the drinking water exposure pathway is associated with the highest potential exposure to inorganic ground water constituents, including metals and radionuclides, the potential risks from any other uses of ground water would be lower.

Ammonium and arsenic occur in both background and off-site downgradient ground water at concentrations exceeding NOAEL comparison values (Table 4.3). Ammonium levels are substantially higher than NOAEL comparison benchmarks only in local background ground water and off-site ground water north and northwest of the site. However, these levels of ammonium would not be associated with adverse effects, and they are well below the taste threshold lexcept for the upper end of local background concentrations range) of $35 \mathrm{mg} / \mathrm{L}$ (ATSDR, 1990). Although arsenic is not a site-related constituent of the shallow aquifer ground water, it is evaluated here because it is commonly present in background ground water in the site area. The arsenic levels exceed the NOAEL comparison criteria in background water and in water from one off-site well (134, northwest of the site). Again, although these levels of arsenic could be associated with adverse health effects following long-term use of ground water for drinking, no health problems are expected from incidental water ingestion.

Uranium is the site-related constituent that exceeded the comparison value only in one off-site well (109, west of the site). As with arsenic, the uranium level observed in water from this well would not result in adverse health effects following incidental consumption of the water.

Sulfate is the only constituent present at levels that could result in short-term effects, manifested as diarrhea, following ingestion of ground water from off-site locations downgradient of the site (west and north of the site but not to the northwest) and from some background locations (see the upper end of regional background water quality). However, sulfate-induced diarrhea would terminate after the cessation of exposure.

Other constituents listed in Table 4.3 are present in ground water at levels below their respective NOAEL comparison values or are essential nutrients and their levels observed in ground water fall within nutritional ranges.

In summary, the results of this analysis indicate that both background ground water and off-site downgradient ground water are not suitable for drinking water due to 
their chemical characteristics and, therefore, are of limited use as defined in Section 5.0. In addition, data presented in Table 4.3 clearly indicate that site-related contamination does not substantially degrade water quality beyond natural conditions.

\section{Environmental concerns}

There are no known surface expressions of the site-affected ground water downgradient of the site. However, site-affected ground water discharges to Mill Creek, both naturally and temporarily through on-site dewatering wells (see Section 3.0). As discussed in Section 3.0, the incremental contamination from these discharges appears to have a negligible impact on surface water quality in Mill Creek. Therefore, no environmental harm is expected to be associated with this ground water now or in the future. However, there is a possibility that some terrestrial plants roots (e.g., trees) may extend into the shallow site-affected ground water. To assess the possibility of adverse effects to terrestrial plants from the above-mentioned scenario, the ground water constituent concentrations are compared to available screening benchmark concentrations (Table 4.4).

As can be seen in Table 4.4, based on available information, the ground water constituent concentrations would not adversely affect terrestrial plants. However, the salinity (concentrations of chloride, sodium, sulfate, and TDS) of the water could affect the growth of sensitive terrestrial plants (Wescot and Ayers, 1980). The salinity- associated effects, however, could potentially occur if plant root systems extend into the shallow site-affected ground water as well as the background ground water in certain areas.

\subsubsection{Risk-based evaluation of on-site land uses}

This section examines whether or not current and projected future on-site land uses could be associated with human and environmental exposures to the site-affected shallow ground water, and whether or not the potential exposures could result in adverse health effects.

As discussed in Section 4.1.2, a 28-ac (11-ha) portion of the site land the southeast corner) has been developed into a golf driving range. The remaining portion of the site is currently vacant. Possible plans for the site land development could be associated with excavations and, consequently, a transient surface exposure of the shallow unconfined aquifer ground water. Another scenario considers permanent surface exposure of the shallow site-affected ground water in the form of a golf course pond.

Under these land use scenarios, ground water constituent concentrations could be lower than currently observed due to effects of precipitation. For the purpose of this evaluation, the constituent concentrations in the surface exposed ground water are conservatively assumed to be at the levels observed at present. 
Table 4.4 Comparison of the off-site shallow ground water constituent concentrations to screening benchmark concentrations for terrestrial plants

\begin{tabular}{|c|c|c|c|c|c|}
\hline \multirow[b]{2}{*}{ Constituent } & \multicolumn{4}{|c|}{ Off-site ground water concentration (mg/L) } & \multirow{2}{*}{$\begin{array}{c}\text { Screening } \\
\text { Benchmark } \\
\text { Concentration } \\
\text { for Plants }\end{array}$} \\
\hline & $\begin{array}{c}\text { West MW } \\
011 \\
\end{array}$ & $\begin{array}{c}\text { Off-site MW } \\
109 \\
\end{array}$ & North MW 008 & $\begin{array}{l}\text { Northwest } \\
\text { MW } 134\end{array}$ & \\
\hline $\begin{array}{l}\text { Ammonium } \\
\text { Barium } \\
\text { Calcium } \\
\text { Chloride } \\
\text { Fluoride } \\
\text { Iron } \\
\text { Magnesium } \\
\text { Manganese } \\
\text { Molybdenum } \\
\text { Potassium } \\
\text { Silver } \\
\text { Sodium } \\
\text { Strontium } \\
\text { Sulfate } \\
\text { Uranium } \\
\text { Radium -226 }\end{array}$ & $\begin{array}{c}2.4 \\
0.02 \\
57 \\
968 \\
1.7 \\
1.53 \\
180 \\
0.12 \\
0.15 \\
50 \\
<0.01 \\
1260 \\
1.5 \\
1420 \\
0.061 \\
0.2\end{array}$ & $\begin{array}{c}2.0 \\
0.01 \\
88 \\
1170 \\
2.4 \\
5.24 \\
271 \\
0.48 \\
0.07 \\
93 \\
<0.01 \\
1770 \\
2.1 \\
2630 \\
0.23 \\
0.2\end{array}$ & $\begin{array}{c}11 \\
0.20 \\
266 \\
925 \\
0.5 \\
1.47 \\
260 \\
0.3 \\
0.01 \\
42 \\
<0.01 \\
697 \\
2.6 \\
2405 \\
0.004 \\
0.5\end{array}$ & $\begin{array}{c}11 \\
0.47 \\
119 \\
215 \\
0.7 \\
1.83 \\
96 \\
0.16 \\
0.02 \\
33 \\
<0.01 \\
210 \\
1.6 \\
450 \\
0.057 \\
0.8\end{array}$ & $\begin{array}{c}\text { NA } \\
\text { NA } \\
\text { NA } \\
\text { NA } \\
5 \\
10 \\
\text { NA } \\
4 \\
0.5 \\
\text { NA } \\
\text { NA } \\
\text { NA } \\
\text { NA } \\
\text { NA } \\
40 \\
\text { NA }\end{array}$ \\
\hline
\end{tabular}

MW $=$ Monitor well.

NA $=$ Not available. 


\section{Human health considerations}

The above-mentioned future activities at the site could potentially result in human incidental dermal contact with site-affected shallow ground water. To determine if the dermal exposure of workers involved in excavations could result in potential adverse health effects, a screening level calculation was performed to estimate dermal absorption doses for the constituents of potential concern for human health (DOE, 1995) and compared to the NOAEL benchmarks (Table 4.5). Dermal exposure to radionuclides such as radium-226 and uranium-234 and -238 is not considered here because no alpha particles are expected to cross the skin barrier. Because chemical-specific absorption factors are not available for metals and other inorganic constituents listed in Table 4.5, it is assumed that they are absorbed across the skin at the same rate as water. This assumption is likely to overestimate any potential exposure contribution from dermal absorption. The results of the screening are shown in Table 4.5.

As can be seen in Table 4.5, exposure doses for the constituents of potential human health concern are well below their respective NOAEL benchmark values. No adverse health effects would be expected to result from dermal absorption associated with incidental occupational skin contact with site-related constituents present in the shallow ground water at currently observed levels.

Therefore, the results of this evaluation suggest that projected on-site excavations would be safe to potentially exposed workers under assumed exposure conditions.

\section{Environmental concerns}

A pond filled with site-affected ground water from the unconfined aquifer may create a hypothetical pathway into the aquatic and terrestrial ecosystem. Therefore, the concentrations of site-related constituents in the most contaminated ground water were compared to aquatic life and terrestrial plants screening benchmarks (Table 4.6).

The results of this analysis indicate estimated concentrations of barium, chloride, and uranium exceed the aquatic life acute and chronic benchmarks; while fluoride, iron, and strontium exceed chronic benchmarks only. These results indicate that an on-site pond, filled with the worst site-affected ground water, would not be acceptable for aquatic organisms.

Plants may be sending roots into the shallow unconfined aquifer because the water is available at a depth of $5 \mathrm{ft}(2 \mathrm{~m})$ or less in some on-site locations. Molybdenum is the only constituent exceeding screening benchmarks for terrestrial plants (Table 4.6). This constituent is just above the benchmark value and uncertainty is associated with its undesirable effects on plants at the observed concentrations (Will and Suter, 1994). However, the salinity-associated effects could prevent salinity-sensitive plants from growing on-site, if plant root systems extent into the shallow ground water. 
Table 4.5 Incidental dermal contact with surface-exposed on-site ground water

\begin{tabular}{lccc}
\hline Constituent & $\begin{array}{c}\text { Exposure } \\
\text { concentrations } \\
(\mathbf{m g} / \mathrm{L})\end{array}$ & $\begin{array}{c}\text { Exposure dose } \\
\text { (mg/kg-day) }\end{array}$ & $\begin{array}{c}\text { NOAEL dose } \\
\text { (mg/kg-day) }\end{array}$ \\
\hline Chloride & & & \\
Fluoride & 2423 & $1.9 \mathrm{E}-3$ & NA \\
Magnesium & 2.3 & $1.8 \mathrm{E}-6$ & $6 \mathrm{E}-1$ \\
Manganese & 802.3 & $6.3 \mathrm{E}-4$ & $3 \mathrm{E}-0$ \\
Molybdenum & 0.36 & $2.8 \mathrm{E}-7$ & $4.7 \mathrm{E}-2$ \\
Sodium & 0.92 & $7.2 \mathrm{E}-7$ & $5 \mathrm{E}-03$ \\
Sulfate & 2525 & $2.0 \mathrm{E}-3$ & NA \\
Uranium & 4678 & $3.7 \mathrm{E}-3$ & NA \\
& 0.26 & $2.0 \mathrm{E}-7$ & $3 \mathrm{E}-03$ \\
\hline
\end{tabular}

Equations and assumptions:

Absorbed dose $(\mathrm{mg} / \mathrm{kg}$-day) $=\mathrm{Cw} \times \mathrm{SA} \times \mathrm{PC} \times \mathrm{ET} \times \mathrm{EF} \times \mathrm{ED} \times \mathrm{CF}$

BS $\times$ AT

Where:

$\mathrm{CW}_{\mathrm{w}}=$ Constituent concentration in water (mg/liter); a) constituent-specific value.

$S A=$ Skin surface area available for contact $\left(\mathrm{cm}^{2}\right)$ (surface area at forearms and hands $11140 \mathrm{~cm}^{2}$ $+840 \mathrm{~cm}^{2}=$ about $2,000 \mathrm{~cm}^{2}$ ] for an adult man) assumed to come in contact with shallow ground water.

$P C=$ Dermal permeability constant for water $(0.001 \mathrm{~cm} / \mathrm{hr})$

$E T=$ Exposure time (1 hour per day)

$E F=$ Exposure frequency (10 days per year)

$E D=$ Exposure duration ( 2 years)

$C F=$ Volumetric conversion factor for water $\left(1\right.$ liter $\left./ 1000 \mathrm{~cm}^{3}\right)$

BW $=$ Body weight $(70 \mathrm{~kg}$ adult men)

$\mathrm{AT}=$ Averaging time (period over which exposure is averaged $=365$ day $\times 2$ years $=730$ days 
Table 4.6 Comparison of on-site shallow ground water concentrations to screening benchmark concentrations for terrestrial plants and aquatic life

\begin{tabular}{|c|c|c|c|c|}
\hline \multirow[b]{3}{*}{ Constituent } & \multirow{3}{*}{$\begin{array}{c}\text { On-site } \\
\text { ground water } \\
\text { concentration } \\
\text { (mean) } \\
\end{array}$} & \multicolumn{3}{|c|}{ Screening Benchmark Concentration } \\
\hline & & \multirow[b]{2}{*}{ Terrestrial plants } & \multicolumn{2}{|c|}{ Freshwater aquatic life } \\
\hline & & & acute & chronic \\
\hline Ammonium & $11^{\circ}$ & NA & NA & NA \\
\hline Barium & 0.18 & NA & 0.068 & 0.0038 \\
\hline Calcium & 81 & NA & NA & NA \\
\hline Chloride & 2423 & NA & 860 & 230 \\
\hline Fluoride & 2.3 & 5 & 19.2 & 1.18 \\
\hline Iron & 1.4 & 10 & NA & 1.0 \\
\hline Magnesium & 802 & NA & NA & NA \\
\hline Manganese & 0.36 & 4 & 1.47 & 0.8 \\
\hline Molybdenum & 0.92 & 0.5 & NA & NA \\
\hline Potassium & $200^{\mathrm{a}}$ & NA & NA & NA \\
\hline Silver & $<0.01$ & NA & NA & NA \\
\hline Sodium & 2525 & NA & NA & NA \\
\hline Strontium & 1.39 & NA & 6.1 & 0.62 \\
\hline Sulfate & 4678 & NA & NA & NA \\
\hline Uranium & 0.26 & 40 & & \\
\hline
\end{tabular}

Note: All data are in $\mathrm{mg} / \mathrm{L}$.

${ }^{\text {a } M e d i a n}$ value for the on-site well with the highest concentration for that constituent. . All other values are mean concentrations for the well having the highest levels for that constituent.

NA $=$ Not analyzed.

\section{Summary}

Based on this analysis, the on-site land excavations involving incidental dermal exposure to the unconfined aquifer ground water would not be associated with increased health risks. However, building a pond filled exclusively with the most contaminated ground water would not be acceptable for aquatic organisms to live in. Any other uses of the site land, which were not considered here, should be evaluated upon determination. 


\subsection{APPLICABILITY OF SUPPLEMENTAL STANDARDS}

\subsection{DEFINITION OF SUPPLEMENTAL STANDARDS}

The UMTRA Project is regulated by both EPA and U.S. Nuclear Regulatory Commission (NRC) regulations 40 CFR Part 192 and 10 CFR Part 40, respectively. The DOE must comply with EPA and NRC regulations for remediation of uranium mill tailings and associated ground water contamination and for long-term care. This section provides a review of the regulations pertaining to ground water compliance standards.

On 11 January 1995, the EPA published the final rule for the ground water standards, with which the DOE must comply as it conducts the UMTRA Ground Water Project. The EPA standards have two subparts that apply to the UMTRA Ground Water Project: Subpart B and Subpart C (EPA, 1995).

\subsubsection{Subpart B - Background levels, maximum concentration limits, alternate} concentration limits, monitoring, and natural flushing

Subpart B, "Standards for Cleanup of Land and Buildings Contaminated with Residual Radioactive Materials from Inactive Uranium Processing Sites," requires conducting remedial action at processing sites to ensure that the amounts of residual radioactive materials and associated hazardous constituents in ground water meet any one of the following three criteria:

- Background levels-Concentrations of constituents in nearby ground water that was not contaminated by processing activities.

- MCLs-EPA's maximum concentration of certain hazardous constituents for ground water protection. Hazardous constituents with MCLs that may be present in contaminated ground water at UMTRA Project sites include arsenic, barium, cadmium, chromium, lead, mercury, molybdenum, nitrate, radium, selenium, silver, and uranium.

- Alternate concentration limits $(A C L)$-Concentrations of contaminants that may exceed the MCLs; or, limits for those constituents without MCLs. If DOE demonstrates, and NRC concurs, that human health and the environment would not be adversely affected, the DOE may meet an ACL.

Subpart B also defines limited-use ground water. Ground water may be classified as limited-use if the TDS exceed $10,000 \mathrm{mg} / \mathrm{L}$, there is widespread surrounding contamination that cannot be cleaned up using treatment methods reasonably employed in public water supply systems, or the quantity of ground water available to a well is less than $150 \mathrm{gal}(570 \mathrm{~L})$ per day. 


\subsubsection{Subpart C - Application of Supplemental standards}

Subpart C, "Implementation," provides guidance for implementing methods and procedures that will reasonably assure the public that the provisions of Subpart $B$ are satisfied.

Subpart C specifies eight conditions for which the DOE may apply supplemental standards to contaminated ground water (40 CFR \$192.2). These conditions are supplemental to background levels, MCLs, or ACLs. The conditions that most likely would apply to the ground water near the Vitro site are the following:

- The remediation of ground water quality at any designated processing site is technically impracticable from an engineering perspective.

- The ground water is not a current or potential source of drinking water, in the absence of contamination from residual radioactive materials, due to the following:

- Widespread, ambient contamination, not due to activities involving residual radioactive materials from a designated processing site, exists that cannot be cleaned up using treatment methods reasonably employed in public water systems. Ambient conditions caused by natural or human-induced conditions exclude contributions from residual radioactive materials.

The EPA final rule states that if supplemental stanciards are applied, the DOE must select and perform remedial action that comes as close to meeting the otherwise applicable standard as reasonably achievable. Supplemental standards must also ensure that current and projected uses of the affected ground water are preserved.

\subsubsection{Demonstration of supplemental standard applicability}

Background ground water quality in the shallow unconfined aquifer in the vicinity of the Vitro site supports the limited-use ground water classification. The ambient contamination in background ground water includes dissolved arsenic as well as particulate lead concentrations likely associated with smelters in the Salt Lake Valley.

Evaluation of water rights in the Central Valley area indicates that, in general, there are no current users of shallow ground water in the vicinity of the site or in areas downgradient of the site (that is, between the site and the Jordan River). The general lack of use of the shallow, unconfined ground water throughout the Salt Lake Valley reflects any combination of the following: 1) it yields water slowly, 2) it is readily contaminated by surface activities, and 3 ) there are readily available sources of good quality water from either public water supply systems or wells completed in the principal aquifer. 
Potential future use of the shallow, unconfined aquifer downgradient of the site is unlikely. Present and future land use in the region of the site is primarily commercial and industrial and water is supplied by public water systems. A small number of residences are also currently served by public water supply systems.

Although arsenic-contaminated background ground water could be treated for arsenic with existing treatment techniques, it would not be reasonable to employ such a treatment of the unconfined aquifer because it has not been a viable water resource in the Central Valley area.

\subsection{SUMMARY AND CONCLUSIONS}

\subsubsection{Site conceptual model}

\section{Hydrogeology}

At the Salt Lake Vitro site, site-related ground water contamination occurs in fluvial channel deposits. These channel sand deposits occur in the upper $35 \mathrm{ft}(11 \mathrm{~m})$ of the shallow, unconfined aquifer. Dewatering at the CVWRF adjacent to the site has created a ground water sink in the area. Contaminated ground water on-site is being flushed from the channel sands as ambient (background) ground water migrates toward the site.

Trace metals (uranium, molybdenum, and vanadium) adsorbed onto the aquifer matrix are desorbing during flushing of the channel deposits. Limited data suggest that levels of contaminants are decreasing. Flushing appears to be most rapid in the shallower portions of the channel sands. Deeper portions, for example at $28 \mathrm{ft}$. $[8.5 \mathrm{~m}]$ in HP-12 on the site, are less affected. However, in other areas, naturally high TDS water found near the base of some channel deposits is apparently flushing toward the site (monitor well 008).

\section{Regional and local background water quality}

Regional background water quality data for the confined aquifer indicate widespread occurrence of arsenic due, at least in part, to former smelters and landfills in Salt Lake Valley. Also, water quality in the shallow unconfined aquifer is affected by evapotranspiration and it is readily contaminated because of its proximity to the land surface.

Local background water quality varies with depth and lithology. Ground water in thin splay sands at a depth of about 30 to $40 \mathrm{ft}(9$ to $12 \mathrm{~m})$ has low TDS, reflecting vertical leakage from the deeper confined aquifer and sulfate reduction associated with organic matter in the floodplain deposits. These sands are poor producers of ground water. By contrast, ground water in shallower channel sands has higher concentrations of TDS, reflecting surface recharge and evapotranspiration. Channel sands are better producers of ground water but have poorer quality water, with TDS concentrations of at least $1200 \mathrm{mg} / \mathrm{L}$. Ambient arsenic occurs in the shallow unconfined aquifer near the site at all six background sampling locations. Arsenic 
also occurs at these locations in both the deeper splay sands and the shallow channel sands.

\section{Extent of site-related contamination}

Dewatering at the CVWRF, in conjunction with natural ground water gradients (controlled by water levels in Mill Creek and the Jordan River) and the distribution of channel deposits, has limited the extent of contamination to the site and areas just west of the site (in the area of former monitoring wells 109 and 011 ). Recent field screening of ground water in other areas downgradient of the site did not encounter ground water having clear evidence of site-related contamination. In all cases, ground water samples had uranium concentrations within range of both background ground water and sources of surface recharge (the Jordan River and Mill Creek). The depth of site-related contamination and ambient ground water having high TDS concentrations is limited by the depth of the channel sands (maximum depth of 35 $\mathrm{ft}[11 \mathrm{~m}])$.

\subsubsection{Risk-based evaluation of contaminant effects on current and projected land uses}

\section{Effects on off-site land uses}

A risk-based evaluation of contaminant effects on current and projected land use and associated ground water use off-site determined that site-related contamination does not substantially degrade water quality beyond ambient (background) condition. There are currently no uses of shallow ground water downgradient of the site, and no future use is anticipated due to the predominantly commercial and industrial use of the land and the availability of city and county water supply systems. Incidental consumption of either contaminated ground water or background ground water would not result in adverse health effects, other than short-term effects (manifested as diarrhea) from sulfate.

No environmental harm is expected to be associated with contaminated ground water off-site. Salinity of ground water could potentially affect the growth of sensitive terrestrial plants if the plant root systems extend into the shallow siteaffected ground water, but the same is true of the background ground water in certain areas. Discharge of site-affected ground water naturally and through on-site dewatering has a negligible impact on water quality in Mill Creek and Jordan River.

\section{Effects on on-site land uses}

Risk-based evaluation of the effects of the human exposure to contaminated ground water on-site by dermal contact indicates exposure would not result in adverse health effects. Therefore, on-site excavations would be safe to potentially exposed workers under assumed exposure conditions.

An evaluation of environmental effects of on-site contaminated ground water determined that a pond filled with site-affected ground water would not be acceptable for aquatic organisms. Native plants, sending roots into the shallow 
unconfined aquifer, are not likely to be adversely affected by site-affected ground water.

\subsubsection{Possible use of the Vitro property}

Construction activities at CVWRF, including on-site excavations and pumpage of ground water from the shallow aquifer, are not associated with increased human health risks or environmental harm due to the presence of site-affected ground water. A golf course would not be associated with increased human health and environmental concerns. However, building ponds filled exclusively with the most contaminated ground water would not be acceptable for aquatic organisms to live in. Other uses of site land, which are not considered here, should be evaluated upon determination.

\subsubsection{Evaluation of the application of supplemental standards}

Ground water in the shallow unconfined aquifer is limited-use ground water due to the widespread occurrence of arsenic that is not related to activities at the former processing site. Background ground water from the shallow unconfined aquifer has been found to contain arsenic at all six background locations and at all depths sampled, indicating its widespread occurrence. Arsenic concentrations have ranged up to $0.173 \mathrm{mg} / \mathrm{L}$. Therefore, as discussed in Section 4.0 , the shallow ground water is not a current or potential source of drinking water.

Sources of drinking water are readily available from the confined aquifer in the vicinity of the site. The shallow unconfined aquifer is not a viable ground water resource for drinking water. Therefore, it is not reasonable to clean up the shallow ground water using treatment methods employed in public water systems.

Ground water from the shallow aquifer in the vicinity of the site is not currently used. There are no wells currently, nor are there any known historical wells, completed in the shallow aquifer downgradient of the site. Future use of the shallow aquifer as a source of water near the site is not likely, based on historical trends and the rapid expansion of commercial and industrial facilities in the area. Therefore, the current and reasonably projected uses of site-impacted ground water would be preserved with the application of supplemental standards.

The application of supplemental standards at this site would be protective of human health. The only reasonable pathway of exposure to contaminated ground water is incidental dermal contact. This contact would pose no increased risks to human health.

The application of supplemental standards appears to be protective of the environment. There would be negligible site-related impacts to the environment due to the discharge of ground water to Mill Creek or the Jordan River and negligible impacts to terrestrial plants sending roots into site-affected ground water. 
Flushing of contaminated ground water at the site is occurring due to dewatering at the CVWRF. This limits the potential for migration of site-affected ground water off-site. In the absence of dewatering, Mill Creek and the Jordan River would act as ground water flow boundaries (under natural conditions) and serve to limit potential migration of contaminants.

\subsubsection{Uncertainties}

While further refinements to the site conceptual model could be made, there are no critical data gaps pertaining to the classification of the uppermost aquifer at the Salt Lake City Vitro Processing site as limited use. 


\subsection{LIST OF CONTRIBUTORS}

The following individuals contributed to the preparation of this report.

\begin{tabular}{ll}
\hline Name & Contribution \\
\hline S. Wright & Document sponsor \\
B. Toth, T. Jackson, B. Smith & Primary authors \\
S. Wright, A. Holm, R. Saar & Document review \\
J. Jones & Editing \\
K. De Gruyter & Graphics \\
D. Minchow, L. Keith & Text processing \\
\hline
\end{tabular}




\subsection{REFERENCES}

Arnow et al. (T. Arnow, R. Van Horn, and R. LaPray), 1970. "The Pre-Quaternary Surface in the Jordan Valley," in Geological Survey Research 1970, U.S. Geological Survey Professional Paper 700-D, Washington D.C., pp. D257-D261.

ATSDR (Agency for Toxic Substances and Disease Registry), 1990. Toxicological Profile for Ammonia, Agency for Toxic Substances and Disease Registry.

D. W. Moore \& Associates, Inc., 1992. "Smelters of Salt Lake County", Prepared by D. W. Moore \& Associates, Inc., Salt Lake City, Utah, for the Utah Department of Environmental Quality, Division of Environmental Response and Remediation.

DOE (U.S. Department of Energy), 1994. Vitro Uranium Mill Tailings Remedial Action Project and Central Valley Vicinity Property Remedial Action Project Completion Report, DOE/AL/62350-129, prepared by the U.S. Department of Energy, UMTRA Project Office, Albuquerque, New Mexico.

DOE (U.S. Department of Energy), 1995. Baseline Risk Assessment of Ground Water Contamination at the uranium Mill Tailings Site Salt lake City, Utah, UMTRA DOE/AL/62350-134 Rev. 0, prepared by the U.S. Department of Energy, UMTRA Project Office, Albuquerque Operations Office, Albuquerque, New Mexico.

EPA (U.S. Environmental Protection Agency), 1995. "Ground Water Standards for Remedial Actions at Inative Uranium Processing Sites", Final Rule, U.S. Environmental Protection Agency, 11 January 1995.

FBDU (Ford, Bacon, \& Davis Utah Inc.), 1981. Engineering Assessment of Inactive Uranium Mill Tailings, Vitro Site, Salt Lake City, Utah, DOE/UMT-0102, FBDU 360-00, UC-70, prepared by FBDU, Salt Lake City, Utah, for the U.S. Department of Energy, UMTRA Project Office, Albuquerque Operations Office, Albuquerque, New Mexico.

Harding Lawson Associates, 1990. Final Design Rept., Ground Water Remediation Remedial Design/Remedial Action, Wasatch Chemical Site, Salt Lake City, Utah, Prepared by Harding Lawson Associates, Denver, Colorado, for Entrada Industries, Inc., Salt lake City, Utah, HLA Job No. 18771,049.10 (available from the Utah Dept. of Environmental Quality, Division of Environmental Response and Remediation).

Hely et al. (A. G. Hely, R. W. Mower, and C. A. Harr), 1971. "Water Resources of Salt Lake County, Utah," State of Utah Department of Natural Resources Technical Publication 31.

Hydrometrics, Inc., 1995. Groundwater Technical Memorandum No. 2, former Murray Smelter Facility, Murray, Utah, Prepared by Hydrometrics, Inc. for ASARC Inc., Dec., 1995. 
Lambert, P. M., 1995. "Numerical Simulation of Ground-Water Flow in Basin-Fill Material in Salt Lake Valley, Utah," State of Utah Department of Natural Resources, Technical Publication No. 110-B.

Markos, G., and K. J. Bush, 1983. Geochemical Investigation of UMTRAP Designated Site at Salt Lake City, Utah, GECR \#R-826, Contract \#DE-AC04-82AL18797, Document DOE/UMT/0235, prepared by GECR, Inc., Rapid City, South Dakota, prepared for the U.S. Department of Energy, UMTRA Project Office, Albuquerque Operations Office, Albuquerque, New Mexico.

Mattick, R. E., 1970. "Thickness of Unconsolidated to Semiconsolidated Sediments in Jordan Valley, Utah," in Geological Survey Research 1970, U.S. Geological Survey Professional Paper 700-C, Washington D.C.

Seiler, R. L., and K. M. Waddell, 1984. "Reconnaissance of the Shallow-Unconfined Aquifer in Salt Lake Valley, Utah," Water Resources Investigations Report 83-4272, U.S. Geological Survey in cooperation with Salt Lake County, Salt Lake City, Utah.

Shacklette, H. T. and Boerngen, J. G., 1984. Element Concentrations in soils and Other Surficial Materials of the Conterminous United States, U. S. Geological Survey Professional Paper 1270, 105 p.

TAC (Technical Assistance Contractor), 1992. Salt Lake City Site Average Linear Ground Water Velocity Calculation, SLC-07-92-14-03-00, August 6, 1992, prepared by the Technical Assistance Contractor, Jacobs Engineering Group Inc., for the U.S. Department of Energy, UPDCC File Location No. 2.19.2.7, UMTRA Project Office, Albuquerque Operations Office, Albuquerque, New Mexico.

TAC (Technical Assistance Contractor), 1995. Summary Trip Report at Salt Lake Vitro Site, August 1, 1995, compiled by the Technical Assistance Contractor, Jacobs Engineering Group Inc., for the U.S. Department of Energy, UMTRA Project Office, Albuquerque Operations Office, Albuquerque, New Mexico.

Thiros, S. A., 1995. "Chemical Composition of Ground Water, Hydrologic Properties of Basin-Fill Material, and Ground-Water Movement in Salt Lake Valley, Utah," State of Utah Department of Natural Resources Technical Publication No. 110-A.

U. S. Environmental Protection Agency, 1989. Final Feasibility Study Report for the Mill Site Operable Unit \#1 of the Sharon Steel/Midvale Tailings Site, Midvale, Utah: Prepared by Camp Dresser \& McKee Inc., Denver, Colorado, for the U.S. Environmental Protection Agency, Denver, Colorado, EPA Contract No. 003-8L40, EPA Document Control No. 7760-003-FS-BCBY.

URS Consultants, Inc., 1986. Portland Cement Co. Kiln Dust \#2 and \#3 Superfund Site, Ground Water Activities Rept., Vol. 1, Prepared by URS Consultants, Inc. for the Utah Dept. of Environmental Quality, Requisition No. 41135. 
Utah Division of Air Quality, 1995. Results of air Quality Monitoring, Job \# U005-001, Report \#95-003B, Prepared by Chester LabNet for the Utah Division of Air Quality, $22 \mathrm{p}$.

Waddell et al. (K. M. Waddell, R. L. Seiler, M. Santini, and D. K. Solomon), 1987. "Ground-Water Conditions in Salt Lake Valley, Utah, 1969-83, and Predicted Effects of Increased Withdrawals From Wells, "State of Utah Department of Natural Resources Technical Publication No. 87.

Wescot and Ayers (D. W. Wescot and R. S. Ayèrs), 1980. "Irrigation Water Quality Criteria" in Irrigation with Reclaimed Wastewater - A Guidance Manual, Cornell University Press, Chelsea, MI.

Will and Suter (M. E. Will and G. W. Suter II), 1994. Toxicological Benchmarks for Screening Potential Contaminants of Concern for Effects on Terrestrial Plants: 1994 Revision, ES/ER/TM-85/R1, prepared by Environmental Sciences Division Oak Ridge National Laboratory under direction from the Environmental Restoration Risk Assessment Council, prepared for the U.S. Department of Energy, Office of Environmental Restoration and Waste Management under budget and reporting code EW 20.

\section{CODE OF FEDERAL REGULATIONS}

10 CFR 40, "Domestic Licensing of Source Material," U.S. Nuclear Regulatory Commission.

40 CFR Part 192, Health and Environmental Protection Standards for Uranium and Thorium Mill Tailings, U.S. Environmental Protection Agency (1994). 


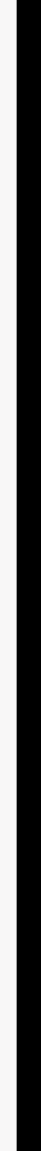
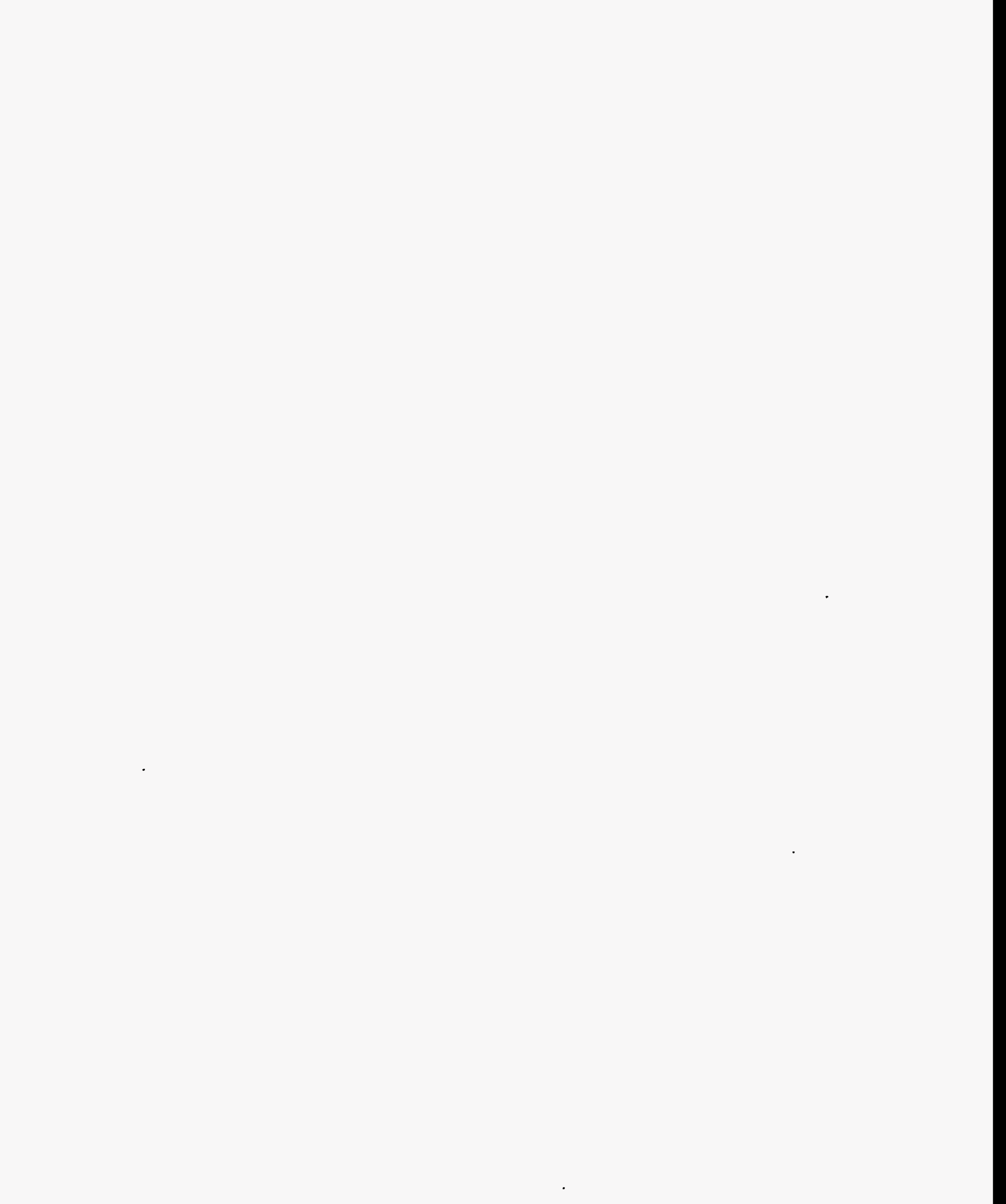


\section{ATTACHMENT 1}

\section{SUMMARY OF SUPPLEMENTAL STANDARDS-RELATED \\ FIELD INVESTIGATION AT THE UMTRA VITRO \\ PROCESSING SITE \\ SALT LAKE CITY, UTAH}





\section{Summary of Supplemental Standards-Related Field Investigation at the UMTRA Vitro Processing Site, Salt Lake City, Utah.}

\section{Purpose and Objectives}

The purpose of the field work was to collect sufficient data to better understand 1) the spatial variations in vicinity background water quality in the shallow, unconfined aquifer (uppermost aquifer), 2) the nature and extent of the UMTRA related contaminants in the uppermost aquifer northwest of the site, and 3) the hydrogeology of the uppermost aquifer. This information was to be used to determine the potential applicability of proposed supplemental standards to the Salt Lake city site based on the presence of limited use ground water due to widespread ambient contamination not caused by activities involving residual radioactive materials at the designated processing site. Also, the information was to help answer questions pertaining to land use planning in the area.

To collect the data, the Hydropunch system was used in an exploratory manner for the collection of subsurface geotechnical data and ground water samples at ten locations. At each location, ground water samples were collected at two separate depths for a total of 19 ground water samples (ground water was not collected at one shallow-depth location because of poor yield). Information collected included lithology, water quality data, and static water levels. Well points were permanently installed adjacent to five of the Hydropunch locations.

\section{Summary of Hydropunch Activities}

Choice of sampling locations

To meet data objectives, 9 locations were chosen downgradient (to the north, northwest, and west) of the site and 8 locations were chosen upgradient (to the east and south) of the site. These preliminary locations were chosen to provide lateral coverage of the area. The preliminary locations included several alternate choices. Landowners were then contacted and, as anticipated, access was denied at several of the chosen locations upgradient and downgradient of the site. Ultimately, access agreements were obtained for 11 of the original 17 locations. Of these, one location to the northwest was determined to be inaccessible during because of its location in a low, muddy area adjacent to the Jordan River. The remaining 10 locations were determined to be accessible during the field effort, and sampled using Hydropunch. These included 5 upgradient and 5 downgradient locations.

Hydropunch sampling and well point installation

The Hydropunch field work was done in three phases: 1) collection of geotechnical data, 2) collection of ground water samples, and 3 ) installation of well points. During the first phase, cone penetrometer testing (CPT) data were collected from each location to a depth of 40 feet. Data collected were standard CPT data (ASTM D3441-86) for cone tip resistance, sleeve friction ratio and geotechnical parameters derived from these measurements. Logs of the data were generated by computer during operation of the tests. These logs were used to determine the depth and distribution of several lithologic 
types - gravely sands, sands, interbedded (mixed) sand and silty clay, and silty clay (see attached logs). Pore pressure dissipation logs were used to determine the relative permeability of each lithologic type. Equilibrium pore pressure testing was used to measure the hydrostatic water at a given depth (see attached logs), and thus the approximate depth to the water table.

CPT data at location HP-1 were compared to borehole lithologic logs in adjacent monitoring well SLC-01-133. This comparison found good agreement between the penetrometer data and the borehole log. Surveyed water levels in Mill Creek and the Jordan River were compared to the water table computed from a pressure tests at adjacent Hydropunch locations. It was assumed that the water levels at these Hydropunch locations, both within 100 feet of the rivers, would closely reflect those of the nearby surface water. The results of this QC check indicated that the Hydropunch water level was accurate to no more than $+/-2 \mathrm{ft}[0.6 \mathrm{~m}]$.

The second phase was to collect water samples from two depths at each location. It was anticipated, based on results from DOE monitoring wells, that ground water quality would vary with depth on and around the site. Therefore, the intent was to collect a sample near the surface (between 11 and 14 feet [3.3 - 4.3 $\mathrm{m}]$ below the surface), and at a greater depth (between 22 and 38 feet $[6.7-11.6 \mathrm{~m}$ ). Results from the first phase of work were used to identify sands which could produce ground water and guide the choice of the two sampling depths. Samples were collected, filtered $(0.45$ micron filter $)$, and analyzed for field parameters, including temperature, specific conductivity, $\mathrm{pH}$, oxidation-reduction potential, alkalinity, sulfate, chloride, and molybdenum.

In one case (HP-1) no shallow sand was present, and only one sample was collected from the sand encountered (at about $35 \mathrm{ft}[11.7 \mathrm{ml}$ ). Two samples were collected at each of the other locations. At 5 locations, two discrete sands were sampled; a shallow, relatively thick sand, and a deeper zone of relatively thin sands (locations HP-2, $-4,-14,-15$, and 16). Sampling of these two lithologic types determined that ground water in the shallower sands generally had higher chloride and sulfate than ground water in the deeper zone. In fact, sulfate was generally not present in the deeper zone. The deeper sand at location HP-4 was an exception, having water quality similar to that in the shallow sands (see attached table).

The thickest (up to 35 feet $[11.7 \mathrm{~m}$ ) and coarsest sand units were encountered in the upper portions of the shallow aquifer at the remaining 4 locations (HP-6, -10, -12, and 13). In these cases, samples were collected from the most permeable zone located nearest the surface (zones at 11 to $13 \mathrm{ft}[3.4-4.0 \mathrm{~m}]$ ) and the most permeable zone closest the base of the sand unit (zones at 21 to $28 \mathrm{ft}$ [6.4-8.5 m]). Sampling at these depths indicated that, at three locations, the deeper zone had the higher concentrations of sulfate and chloride. However, at location HP-10, water quality was similar in both the shallow and deep zones.

Field analyses for uranium were planned. However, problems with the spectroscopic equipment were encountered. Time constraints prevented fixing the problem and performing the analyses. However geology and available water quality results were sufficient to guide the placement of well points and to determine which samples should be analyzed for uranium in the lab. 


\section{Thursday, February 29}

1. Tim Jackson arrives onsite.

2. Performed utilities clearance with representatives from US West.

3. Completed piezocone probe holes at locations 2, 4, 6, and 14. Each hole was punched to a depth of $40 \mathrm{ft}$ BGS.

4. Gary Black (Condi Foods) signed access agreement for location 10.

5. Surveyed locations 2, 4, and 6, and water elevation of Mill Creek and Jordan River.

6. Obtained authorization from Lee Colvin (Salt Lake County representative) to install additional HydroPunch holes on county property located south of 3300 South. and east of 900 West. Current access agreement for location 14 will also cover proposed additional locations. Colvin requested that the county receive a summary of the data collected in this area.

7. Performed reconnaissance of Condi Foods property. Determined that CPT rig can access this property to perform piezocone push, collect ground water samples, and install well point.

8. Performed reconnaissance of county property described in item 5 above. Chose two potential background locations for piezocone data and water sample collection. Also discovered that the county has completed two well clusters (assumed to be used for pump tests) on the county property.

\section{Friday, March 1}

1. Received authorization to install two additional background HydroPunch holes on county prison property.

2. Set up account with Adler Construction to provide bulldozer services if CPT rig gets stuck in Vitro field.

3. Completed piezocone probe holes at locations 1, 10, 12, 15, and 16. Each hole was punched to a total depth of $40 \mathrm{ft}$.

4. Continued survey activities.

Note: Alta Geo rig was able to access locations 1 and 12 in Vitro field. Bulldozer services were not needed. 


\section{Saturday, March 2}

1. Collected and analyzed ground water samples from selected depths at location 14, 15, and 16. Ground water quality results are listed in Table 1. A sample duplicate and equipment blank was collected and is associated with sample ID 418 at location 15.

\section{Continued survey activities.}

\section{Sunday, March 3}

1. Collected ground water samples from selected depths at location 10, 13, and 14. Ground water quality results are listed in Table 1.

Average time to complete a sample round at each location is approximately $3.5 \mathrm{hrs}$. At least $2 / 3$ of this time involves rig setup, tripping rod, decon activities, and hole grouting. Average analytical time for alkalinity, chloride, sulfate, molybdenum, and alkalinity is one hour per sample.

2. The PCMIA data link (used for uranium analyses) between the computer and spectrophotometer is not responding and uranium analysis cannot be performed. However, chloride, sulfate, and piezocone geology data are sufficient to screen ground water for lab analyses and well point completion.

\section{Monday, March 4}

1. Collected ground water samples from selected depths at locations 1 and 12 in Vitro field. Ground water quality results are listed in Table 1.

Entrance to Vitro field was muddy - CPT rig got stuck. A bulldozer was supplied by Adler Construction which logged approximately 15 minutes to tow out CPT rig. Not sure how much Adler will bill Jacob's. Left message with Bill Horodus (Adler project manager) to contact Terry Rodriguez to obtain PR No. for invoicing and discuss charges.

Late in the day, attempted to collect ground water sample from location 2 lOxbow Prison Facility) at a depth of $11 \mathrm{ft}$ BGS. Formation produced no ground water. Decided to secure rig with sample chamber still at depth and see if sample chamber fills overnight.

2. Tim Jackson successfully downloaded 3 of the 4 data loggers onsite. The batteries in the fourth data logger (DH-20) are apparently dead which prevented download of the data. 
APPLIED RESEARCH ASSOCIATES INC.

\section{New England Division \\ Data Acquisition System \\ Uersion 6.00}

\section{Pore Pressure Dissipation Test}

$\begin{array}{lcll}\text { Test Id }: \text { CPT-1 } & \text { Filename : A01M607P.034 } & \text { Total Test Duration } & \text { 5. minutes_ } \\ \text { Depth }= & 34 . f t & \text { Th } & \end{array}$

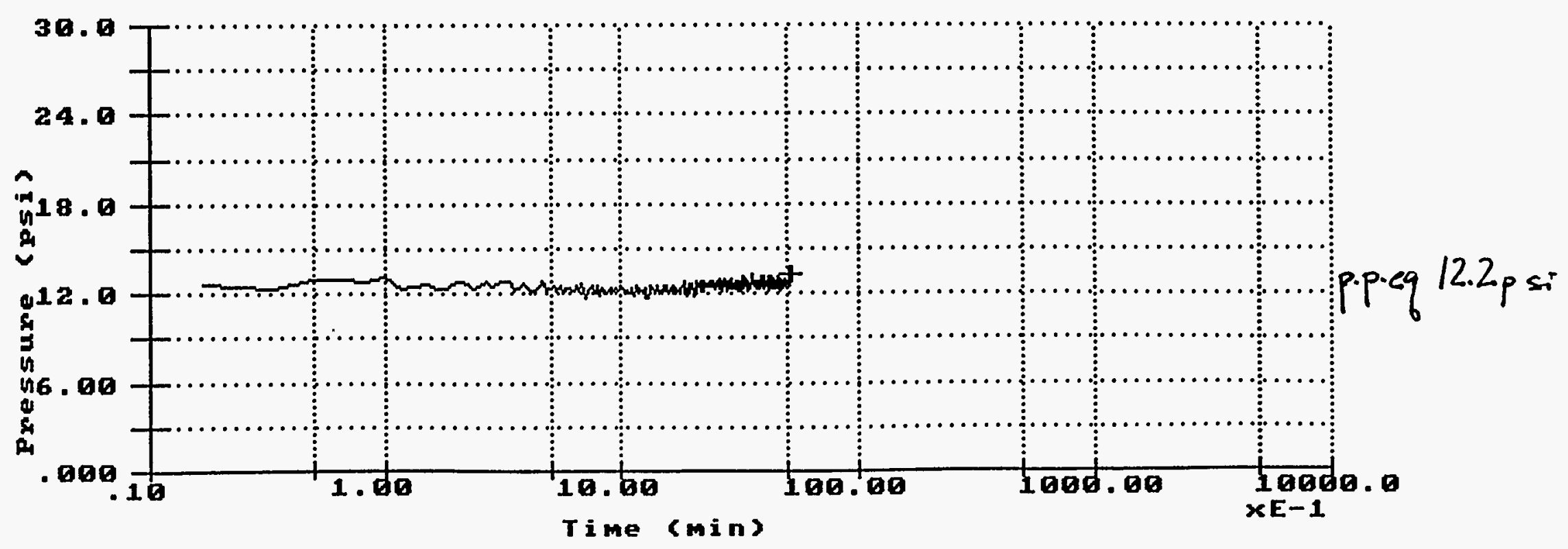


CPT-2 ALTA GEO
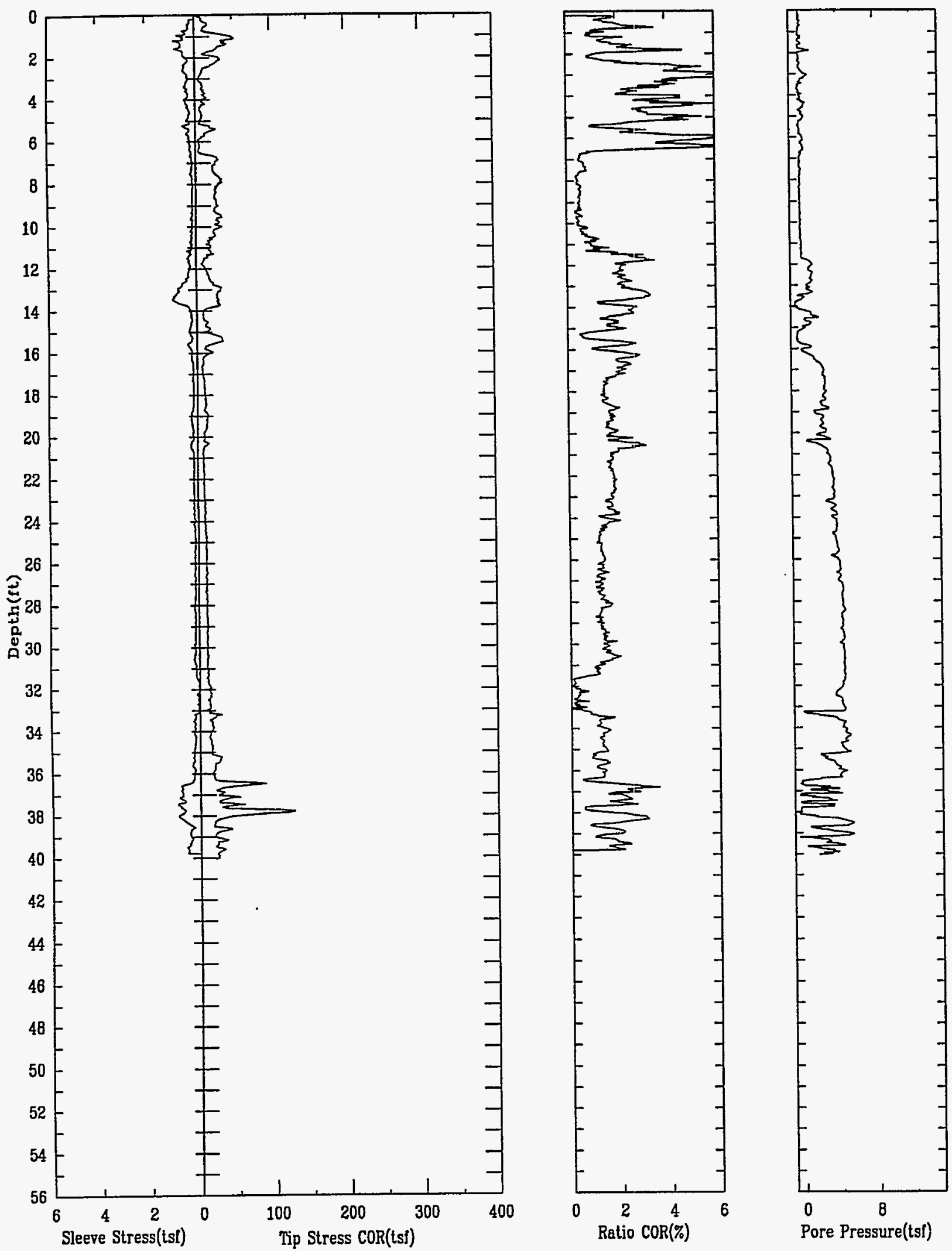
$\begin{array}{lr}\text { CPT-2 } & \text { ALTA GEO } \\ \text { OXBOW } & \text { O2/29/96 } \\ & \text { GW }\end{array}$
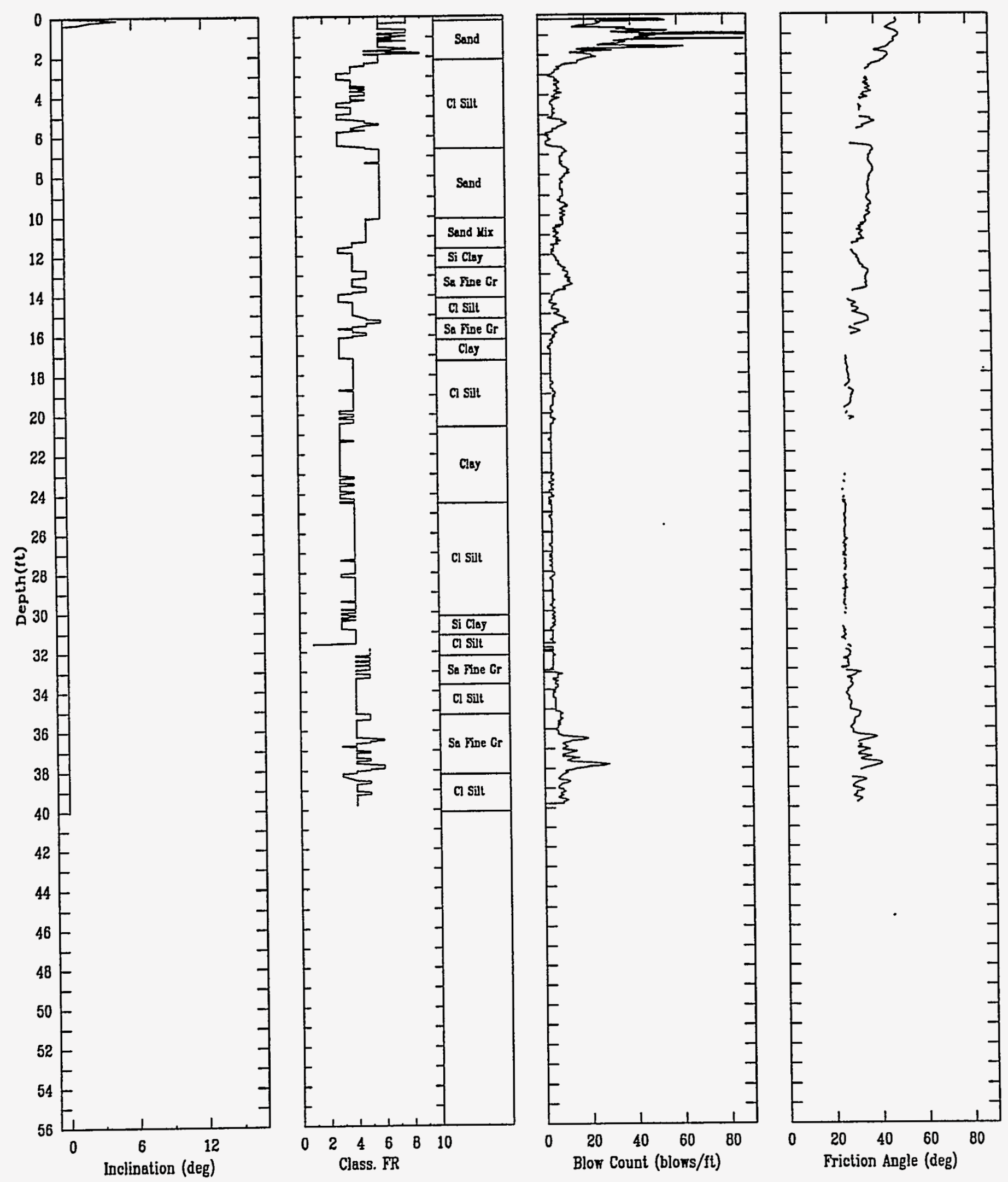
APPLIED RESEARCH ASSOCIATES INC.

New England Division

Data Acquisition System

Version 6.00

\section{Pore Pressure Dissipation Test}

Test Id : CPT-2 Depth =
Filename : A29F605P.015

Total Test Duration
8. minutes_

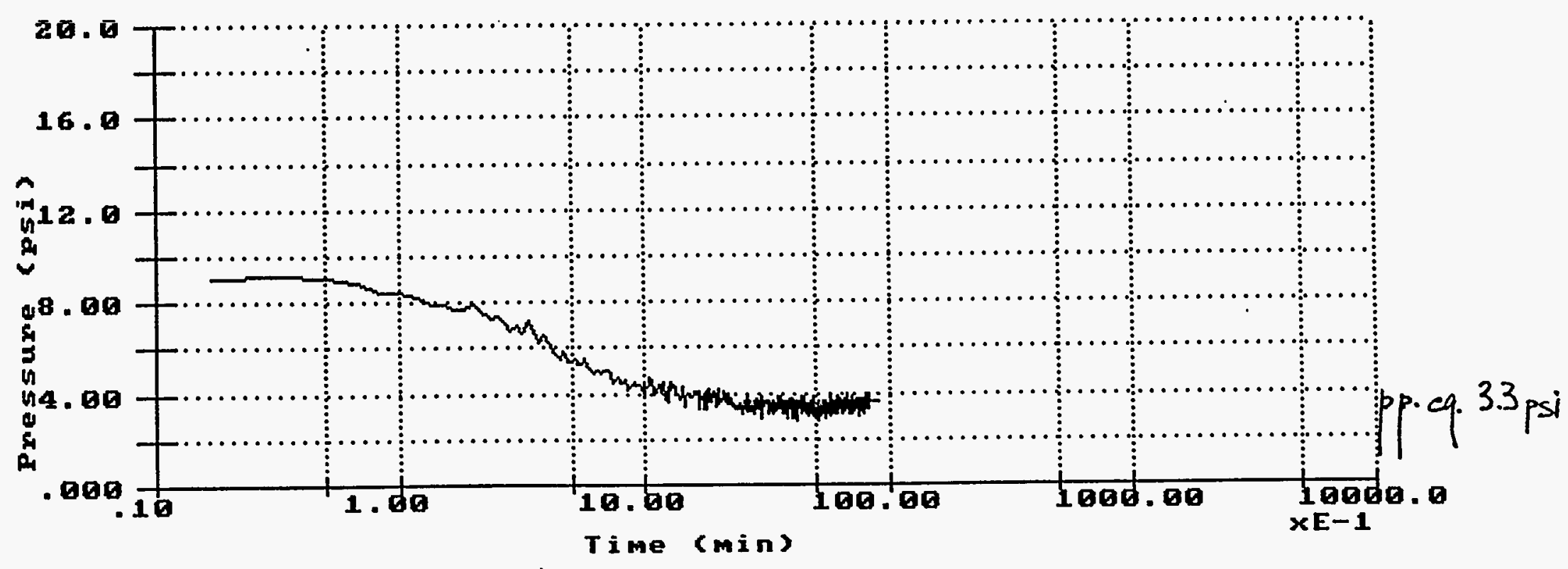


The third phase was to install monitoring well points. The locations for the well points were driven by practical considerations. There was a greater need for water quality and water level data off-site as compared to on-site. Therefore all well points were completed off-site. Background locations south of the site, on a large tract of county land, were in an area of ongoing construction activities. These activities prevented the placement of well points at these locations. Therefore, well points were placed at all of the remaining 5 offsite locations.

Water quality data and lithologic data were used to determine the depth of well point screens at each location. Based on historical data, it was known that site-related contamination of shallow ground water is generally associated with higher concentrations of sulfate, chloride, molybdenum, and uranium. Therefore, well points were completed at each location in the sand having the highest concentrations of these site-related indicator parameters (except for uranium). For consistency in comparisons to background, the same criteria were used to place the background well point at location HP-13. These criteria were also used to choose ground water samples to be analyzed for uranium in the laboratory.

All 8 background water quality samples were analyzed for arsenic and uranium to provide a full set of data for determining the concentrations and spatial distribution of these constituents in background.

Results of field and laboratory water quality analyses are presented in the attached table. $\mathrm{OC}$ tests of field analyses indicate that all results are accurate to within at least 10 percent, based on analyses of standards, duplicate samples, equipment blanks, and spikedsamples.

Surface completion of all well points were made using flush-mount vaults having bolt-down manhole-type covers set in a 2 by $2 \mathrm{ft}[0.6$ by $0.6 \mathrm{~m}]$ concrete pad. The integrity of the well points was assured by placing locked caps on the riser within each man-hole vault.

All locations were surveyed using a surveyors level. The surveys used the top of PVC casing in existing monitor wells (known points) as benchmarks for elevations and locations. Closure on two known points indicated that the surveyed elevations are accurate to within $0.1 \mathrm{ft}[0.03 \mathrm{~m}]$ elevation and the locations (northings and eastings) to within $50 \mathrm{ft}[15 \mathrm{~m}]$. Also, water level elevations were determined in each well point, and at several locations along Mill Creek and the Jordan River. 
SLC Supplemental Standards-Related Field Work

Daily Field Activity Reports

Monday, February 26

1. Eric Larsen mobilizes to Salt Lake City.

Tuesdav, February 27

1. Contacted Ron Roberts (CVWRF representative) and informed him of our field schedule.

2. Performed site reconnaissance of all proposed HydroPunch and well point locations.

3. Steve Liston (owner of Valley Forklift) signed access agreement for well point to be installed at location 13.

4. Met with Alta Geo staff and gave them a tour of each HydroPunch and well point location and performed utilities clearance with representative from Utah Power and Light.

5. Performed utilities clearance with representatives from SLC Sewer and Water and SLC Natural Gas.

6. Location 9 was determined to be inaccessible due to very muddy conditions.

\section{Wednesday, February 28}

1. Performed utilities clearance with representatives from South SLC Sewer and Water and SLC Suburban Sanitary District \#1.

2. Determined depth and direction of 42-in.-diameter Grainger/CVWRF intercept conduit. Flagged location 2 approximately $3 \mathrm{ft}$ south of center of conduit.

3. Completed piezocone probe hole at location 13. Hole was punched to a depth of $40 \mathrm{ft}$ BGS. Obtained verification from property owner that telephone line was not in the vicinity of the hole location.

4. Performed reconnaissance of 40 acre tract of county property located south of 3300 South and east of 900 West. 


\section{Tuesday, March 5}

1. Collected ground water samples from selected depths at locations 2,4 , and 6 . Ground water quality results are listed in Table 1.

Returned to location 2 (Oxbow Prison Facility); no ground water had collected in sample chamber which had sat overnight at a depth of $11 \mathrm{ft}$ BGS. Pushed chamber to $16 \mathrm{ft} \mathrm{BGS}$ and collected a ground water sample from that depth.

By the end of the day at location 6, attempted to collect a ground water sample from $22 \mathrm{ft}$ BGS. Very little ground water was flowing into sample chamber. Secured rig with chamber at depth to see if it fills overnight.

2. Tim Jackson ordered a battery pack for the $\mathrm{DH}-20$ data logger to allow data logger to be downloaded. Jackson also performed analyses for chloride, sulfate, and molybdenum on ground water samples collected on Monday (3/4).

\section{Wednesday, March 6}

1. Collected last ground water sample from $21 \mathrm{ft}$ BGS at location 6 (Sample ID 407). Formation production was very poor. Suspect sample chamber was not fully open or clogged. Ground water quality results are listed in Table 1.

2. Installed $1^{7 / 8}$ in. I.D. well points at locations $2,4,6$, and 13 . Completion depths listed below.

\begin{tabular}{|c|c|c|}
\hline on & $\begin{array}{l}\text { Casing } \\
\text { Depth }(\mathrm{ft})\end{array}$ & $\begin{array}{l}\text { Screened } \\
\text { Interval (ft) }\end{array}$ \\
\hline & 16.0 & -24.0 \\
\hline$a$ & $\begin{array}{l}24.0 \\
23.0\end{array}$ & $\begin{array}{l}17.5-24.0 \\
16.5-23.0\end{array}$ \\
\hline & 22.0 & $15.5-22.0$ \\
\hline
\end{tabular}

Well screen and riser sections were 1 meter in length. Each well screen consisted of two 1 meter sections. Well point installation proceeded very smoothly. Average time to install each well point was approximately $1.5 \mathrm{hrs}$.

3. Called Gary Black (representative for Condi Foods property on which well point 10 will be installed) - verified that the proposed location for well point 10 was on Condi property.

4. Battery pack for the DH-20 data logger arrived.

5. Jackson completed analyses for chloride, sulfate, and molybdenum on all ground water samples collected. He shipped all selected sample to respective offsite laboratories for arsenic and uranium analyses.

6. Continued survey activities. 


\section{Thursday, March 7}

1. Installed well point 10. Casing depth at $31.0 \mathrm{ft}$ BGS; screened interval at 25.5 $31.0 \mathrm{ft}$ BGS.

2. Performed alkalinity analyses on all ground water samples collected.

3. Attempted to download data from $\mathrm{DH}-20$ data logger. Experienced communication problems between data logger and laptop computer. Decided to remove data logger and ship it back to Albuquerque for download and repair.

4. Completed survey loop. Data includes location and elevation of all well points installed.

5. Measured water levels in all well points.

Location

WP-2

WP-4

WP-6

WP-10

WP-13

\section{Depth to}

\section{Water (ft BTC) Comments}

5.79

23.90

6.94

3.55

18.06
Water level stabilized

Screen clogged - well requires development

Water level stabilized

Water level stabilized

Water level equilibrating

6. Installed well vaults and locking well caps; poured concrete pads at all well point locations.

7. Demobilized. 
Figure 1.

Site Map Showing

Logging and Sampling Locations

Salt Lake City, Utah, Vitro Processing Site

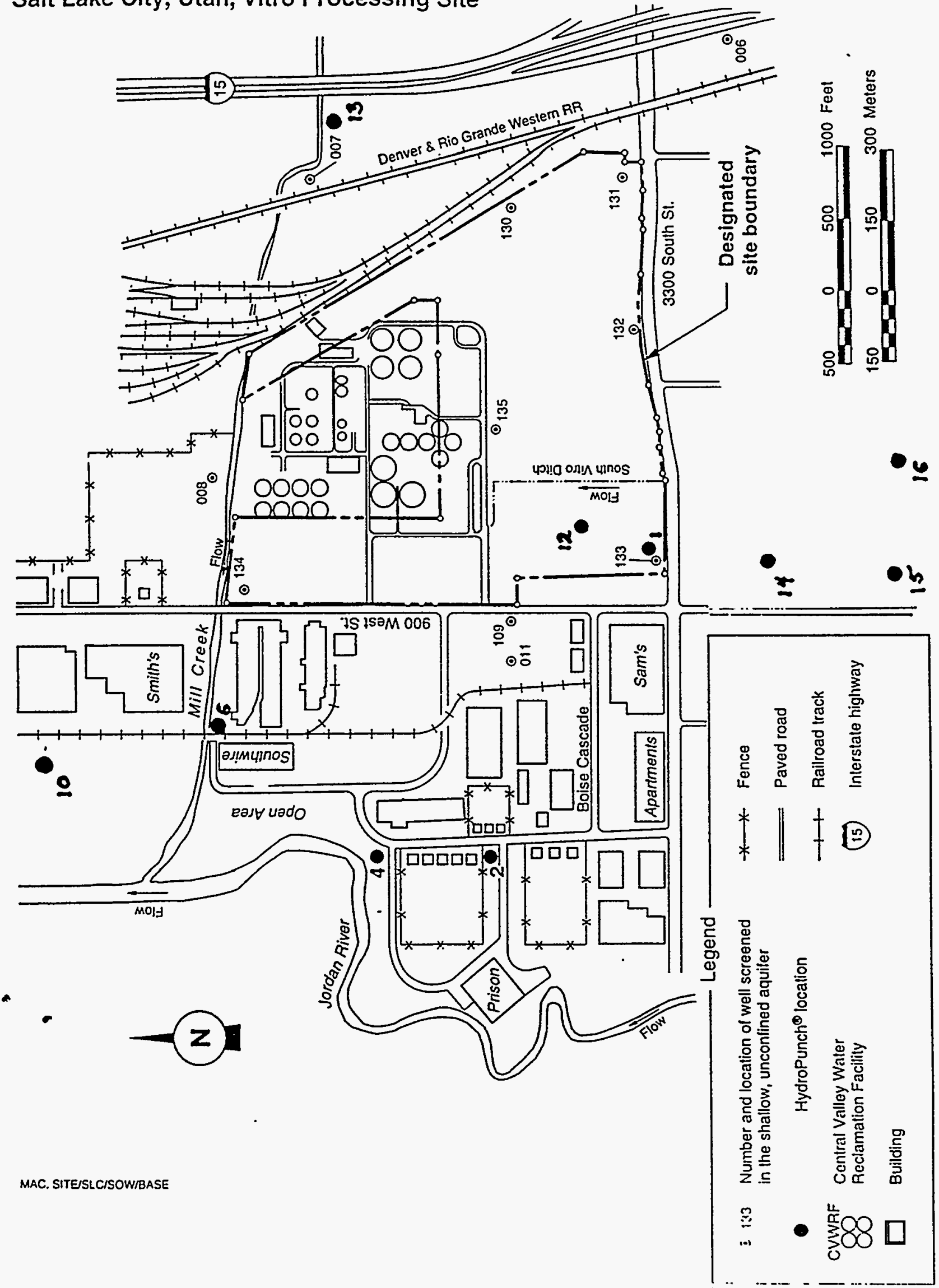


Table 1 Ground water quality results, Salt Lake City Hydropunch Investigation

\begin{tabular}{|c|c|c|c|c|c|c|c|c|c|c|c|c|}
\hline Location & $\begin{array}{c}\text { Sample } \\
\text { ID }\end{array}$ & $\begin{array}{c}\text { Depth } \\
\text { (ft) }\end{array}$ & $\begin{array}{c}\text { Temp. } \\
\text { (C) }\end{array}$ & $\begin{array}{c}\text { Specific } \\
\text { Conductence } \\
\text { (umhos/cm) }\end{array}$ & pH & $\begin{array}{l}\text { Oxydation- } \\
\text { reduction } \\
\text { potential } \\
\text { (mvolts) }\end{array}$ & $\begin{array}{c}\text { Alkalinity } \\
\text { (mg/L) }\end{array}$ & $\begin{array}{c}\text { Chloride } \\
\text { (mg/L) }\end{array}$ & $\begin{array}{l}\text { Sulfate } \\
\text { (mg/L) }\end{array}$ & $\begin{array}{c}\text { Molybdenum } \\
\text { (mg/L) }\end{array}$ & $\begin{array}{c}\text { Uranium } \\
\text { (mg/L) }\end{array}$ & $\begin{array}{c}\text { Arsenic } \\
\text { (mg/L) }\end{array}$ \\
\hline \multicolumn{13}{|c|}{ Upgradient } \\
\hline \multirow[t]{2}{*}{13} & 408 & 13 & 11.1 & 1120 & 7.43 & NA & 490 & 90 & 280 & 0.01 & 0.002 & 0.029 \\
\hline & 409 & 22 & 14.3 & 6730 & 6.94 & 54 & 661 & 1320 & 4000 & 0.03 & 0.021 & 0.053 \\
\hline \multirow[t]{2}{*}{16} & 416 & 11 & 11.1 & 1536 & 7.45 & 114 & 461 & 345 & 370 & $<0.01$ & 0.007 & 0.012 \\
\hline & 417 & 35 & 12.1 & 875 & 7.82 & 60 & 476 & 98 & 0 & $<0.01$ & $<0.001$ & 0.173 \\
\hline \multirow[t]{2}{*}{15} & 418 & 14 & 4.4 & 1452 & 6.84 & 110 & 495 & 290 & 340 & $<0.01$ & 0.003 & 0.009 \\
\hline & 419 & 35 & 11.3 & 670 & 7.83 & 85 & 44 & 47 & 2 & $<0.01$ & $<0.001$ & 0.023 \\
\hline \multirow[t]{2}{*}{14} & 414 & 11 & 9 & 1676 & 7.35 & 126 & 493 & 530 & 430 & 0.01 & 0.010 & 0.021 \\
\hline & 415 & 35 & 11.2 & 476 & 7.79 & -12 & 329 & 17 & 0 & $<0.01$ & $<0.001$ & 0.082 \\
\hline \multicolumn{13}{|c|}{ Downgradient } \\
\hline 1 & 401 & 37 & 13.2 & 537 & 8.07 & 118 & 337 & 18 & 0 & $<0.01$ & na & na \\
\hline \multirow[t]{2}{*}{12} & 412 & 12 & 9.3 & 3250 & 7.04 & 48 & 732 & 498 & 1200 & 0.02 & 0.008 & na \\
\hline & 413 & 28 & 13.7 & 7930 & 7.23 & -45 & 1883 & 750 & 5000 & 0.09 & 0.008 & na \\
\hline \multirow[t]{2}{*}{2} & 402 & 16 & 11.4 & 2450 & 7.19 & 60 & 505 & 505 & 580 & $<0.01$ & 0.012 & na \\
\hline & 403 & 38 & 12.8 & 421 & 8.03 & -199 & 272 & 130 & 2 & $<0.01$ & na & na \\
\hline \multirow[t]{2}{*}{4} & 404 & 12 & 11.8 & 2230 & 6.8 & 99 & 950 & 393 & 570 & 0.03 & na & na \\
\hline & 405 & 24 & 14.2 & 2270 & 7.24 & 71 & 560 & 390 & 500 & 0.02 & 0.003 & na \\
\hline \multirow[t]{2}{*}{6} & 406 & 11 & 9.5 & 764 & 7.04 & 91 & 430 & 54 & 120 & 0.02 & na & na \\
\hline & 407 & 21 & 9.0 & 2820 & 7.51 & -83 & 505 & 498 & 1300 & $<0.01$ & 0.004 & na \\
\hline \multirow[t]{2}{*}{10} & 410 & 11 & 10.7 & 4500 & 7.01 & -11 & 579 & 1058 & 1700 & $<0.01$ & & ná \\
\hline & 411 & 27 & 12.2 & 4930 & 7.12 & -54 & 612 & 1115 & 1650 & $<0.01$ & 0.018 & na \\
\hline
\end{tabular}



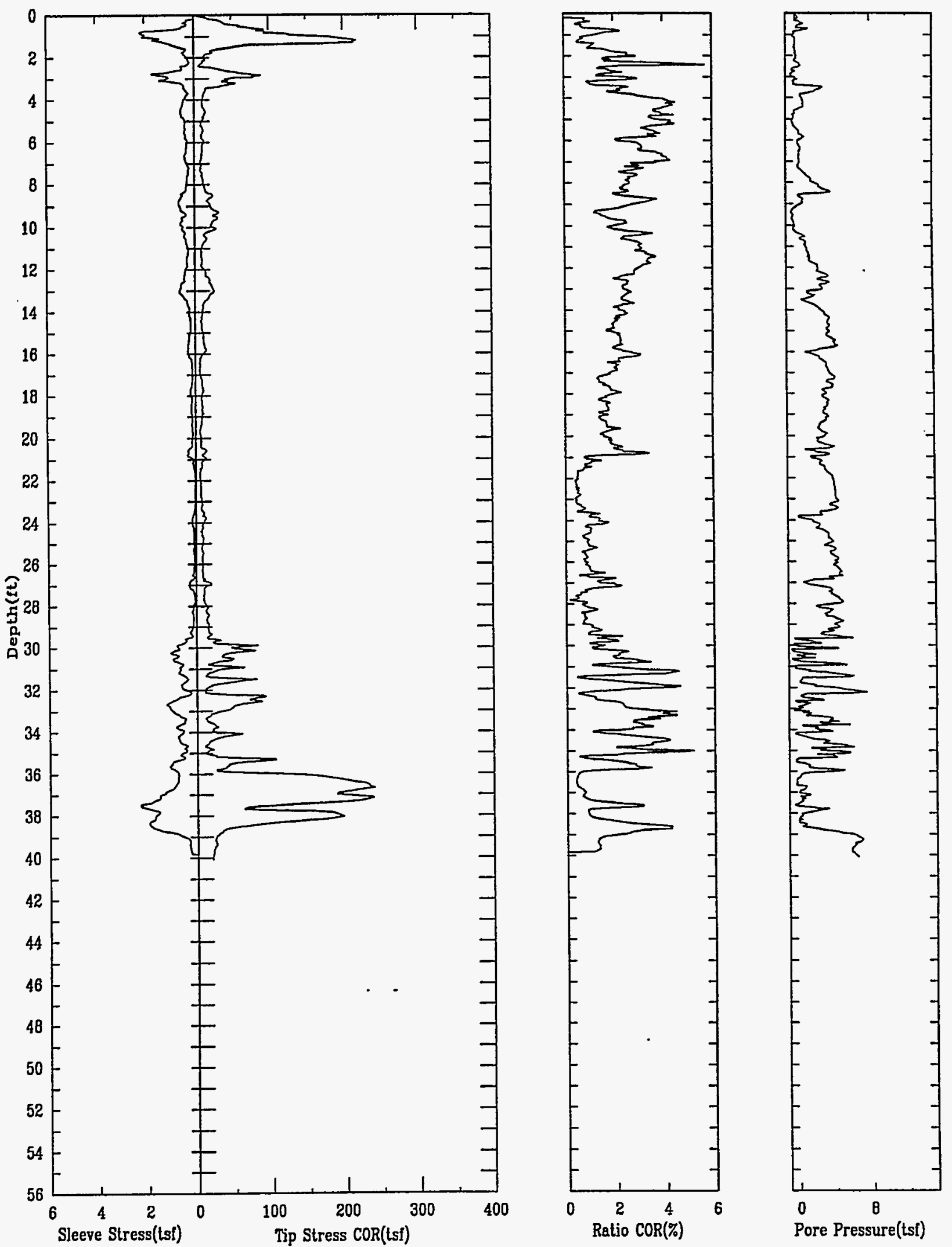
CPT-1 ALTA GE0 03/01/96

WELL 133

GW
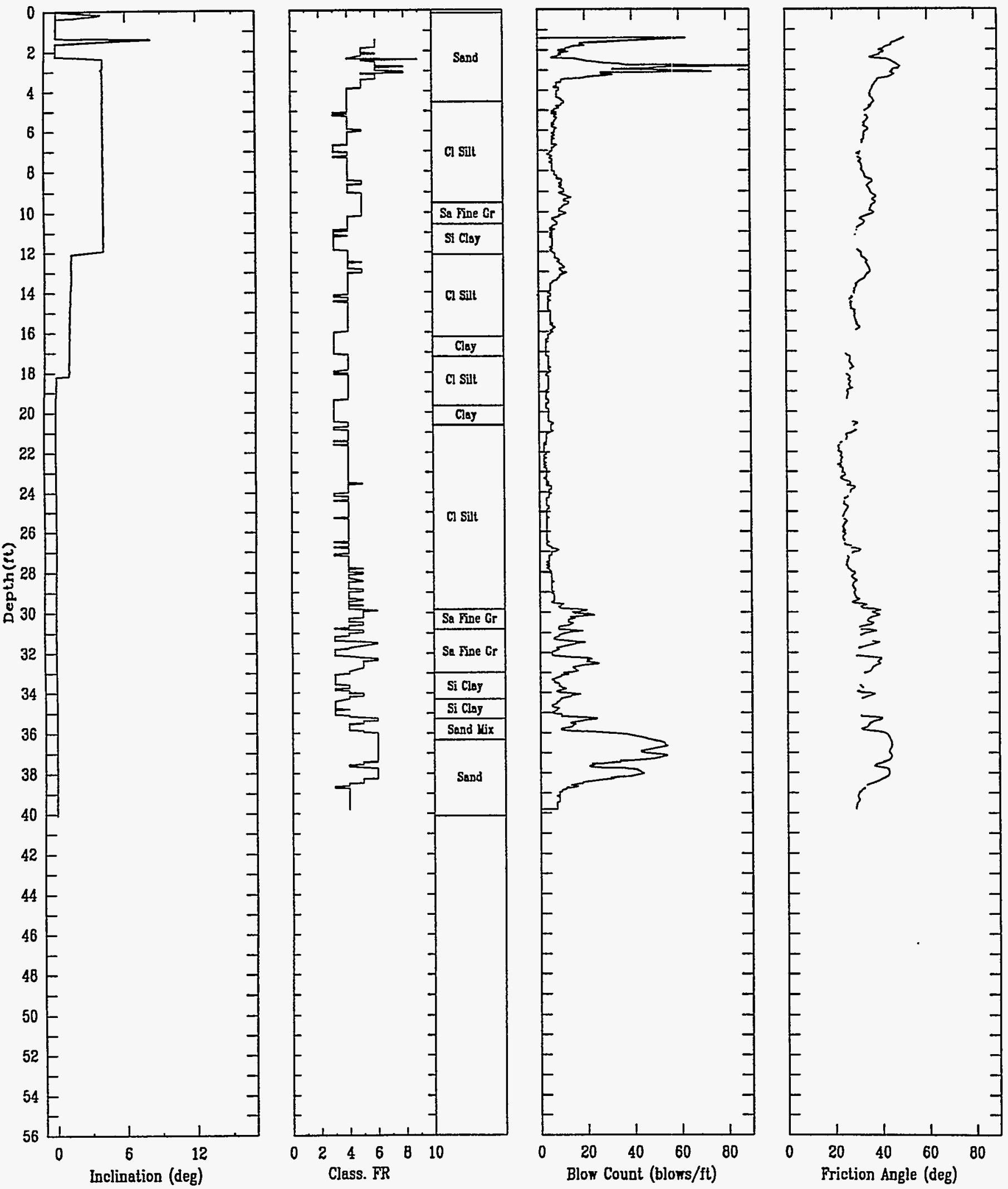
$\begin{array}{cr}\text { CPT-4 ALTA GEO } & 02 / 29 / 96 \\ \text { JORDAN RIVER TRAIL } & \text { GW }\end{array}$
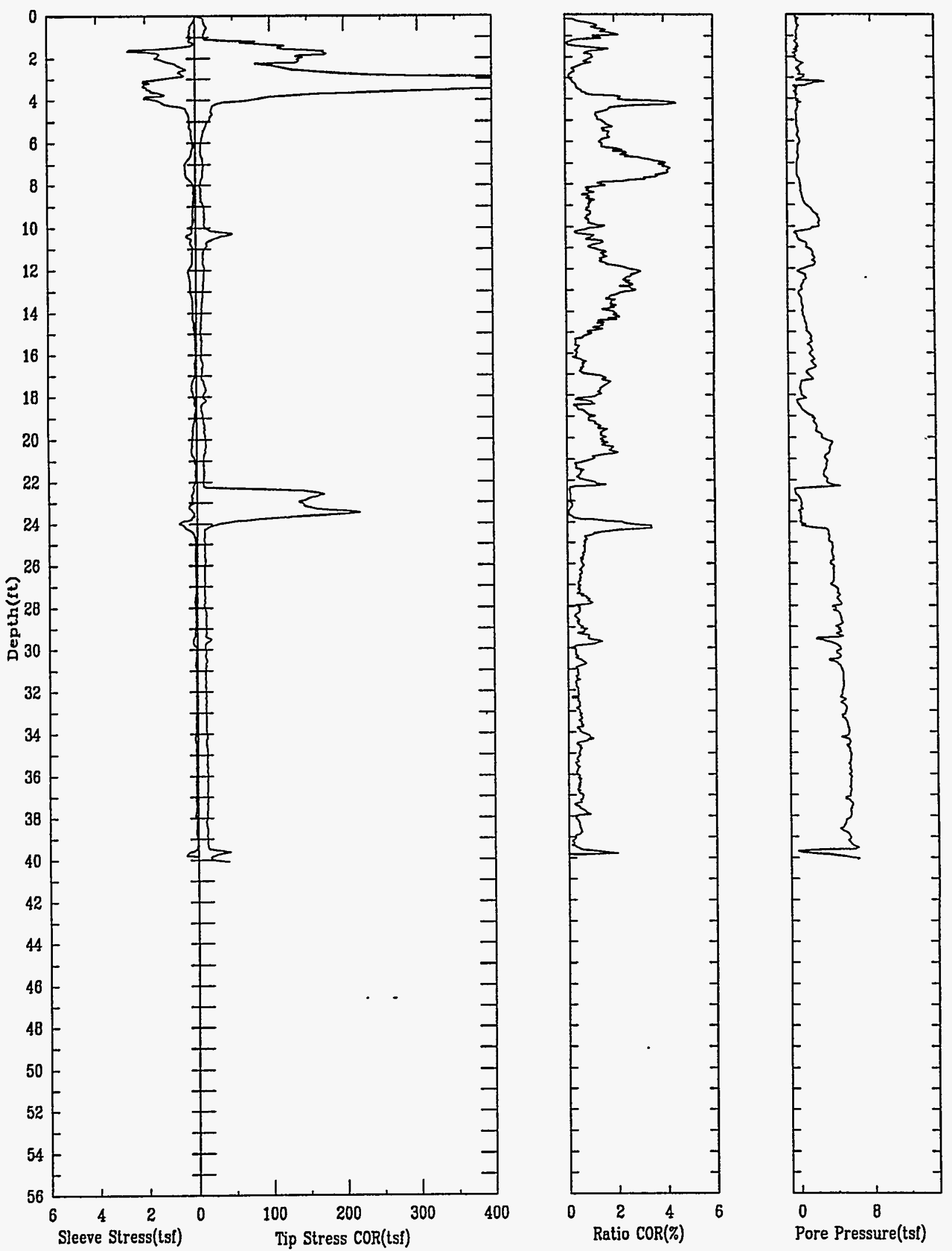
CPT-4 ALTA GEO

JORDAN RIVER TRAIL
02/29/96

GW
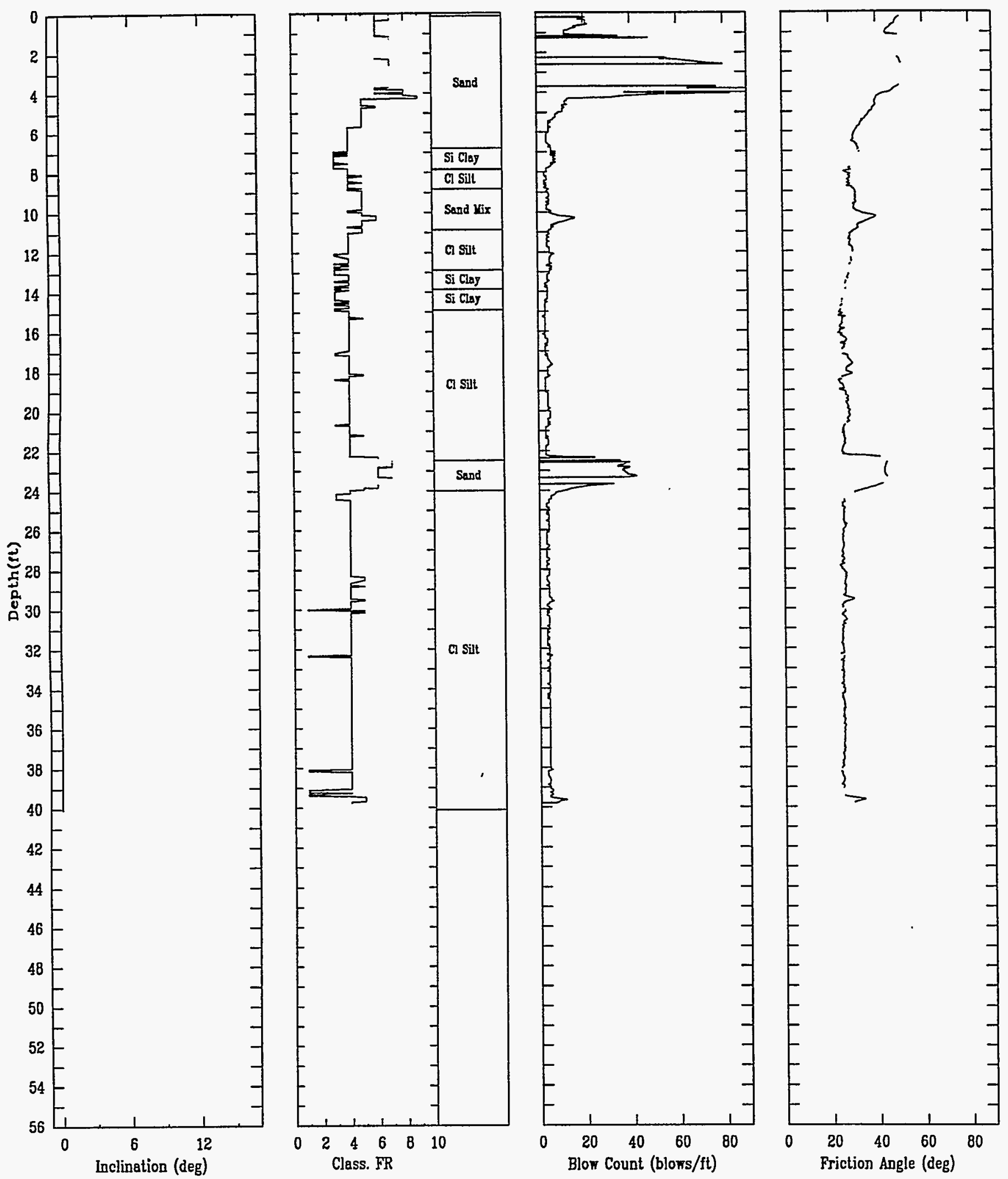

File A29P607.ECP 


\title{
APPLIED RESEARCH ASSOCIATES INC.
}

\author{
New England Division \\ Data Acquisition System \\ Version 6.00
}

\section{Pore Pressure Dissipation Test}

$\begin{array}{lcll}\text { Test Id : CPT-4 } & \text { Filename : A29F607P.018 } \\ \text { Depth }= & \text { 18.ft } & \text { Total Test Duration } & \text { 10. minutes_ }\end{array}$

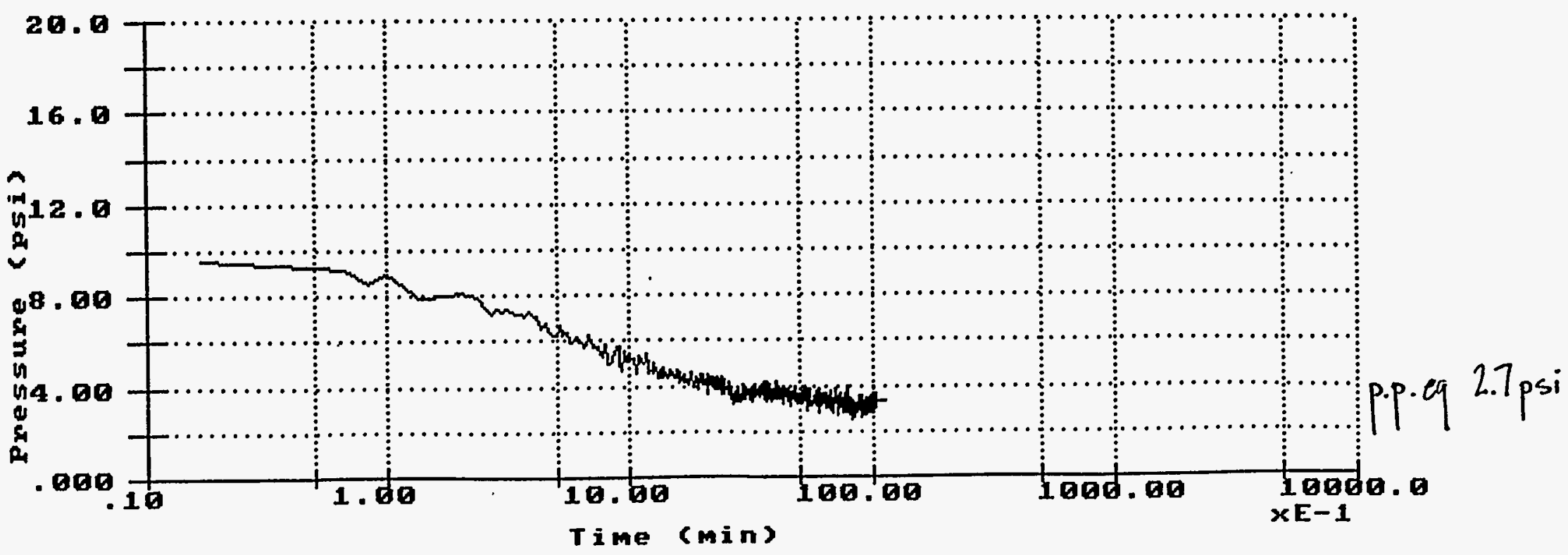


CPT-6 ALTA GEO

PAUL BUEHNER

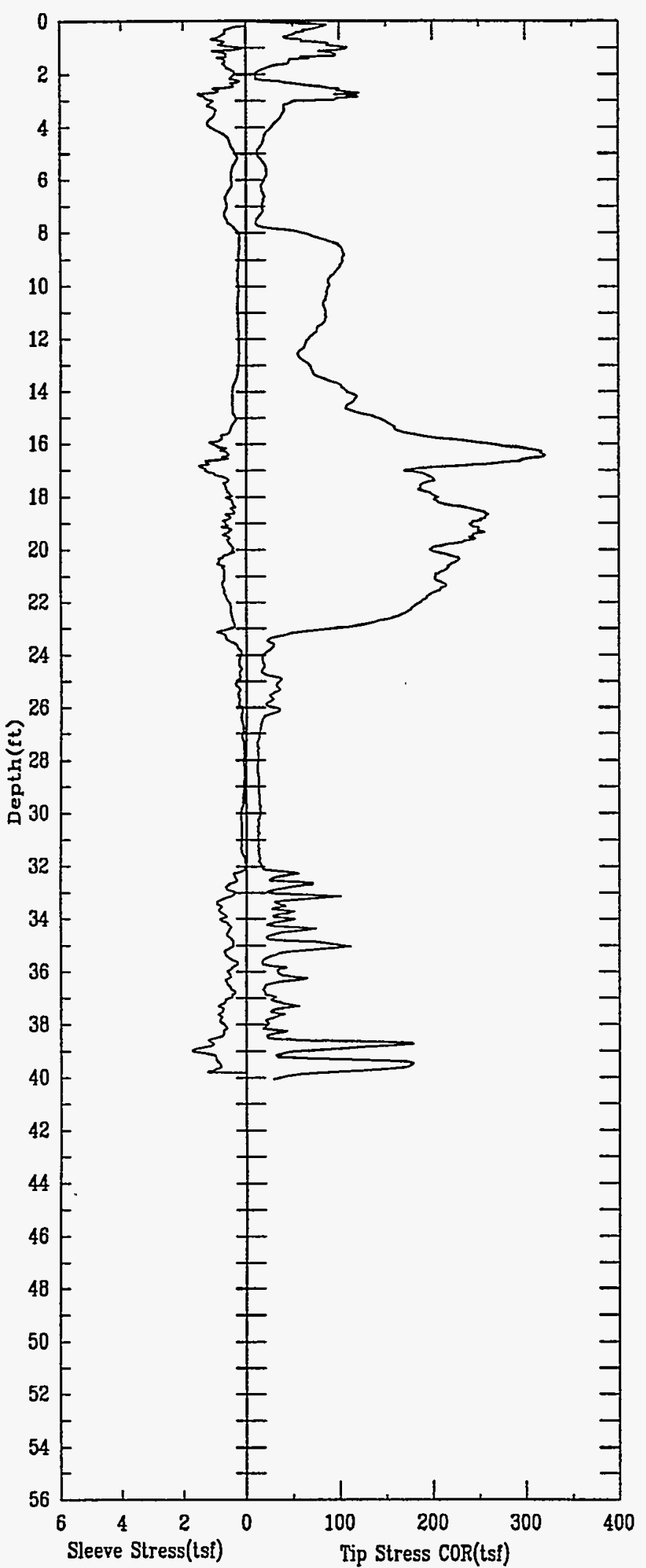

02/29/96

GW
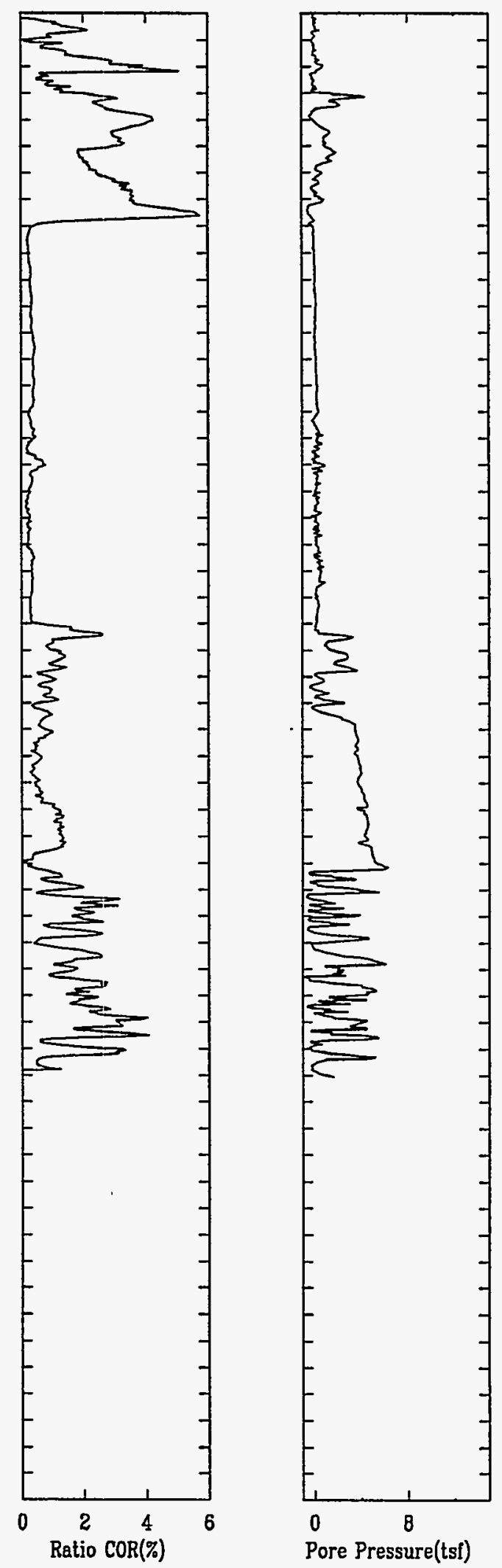


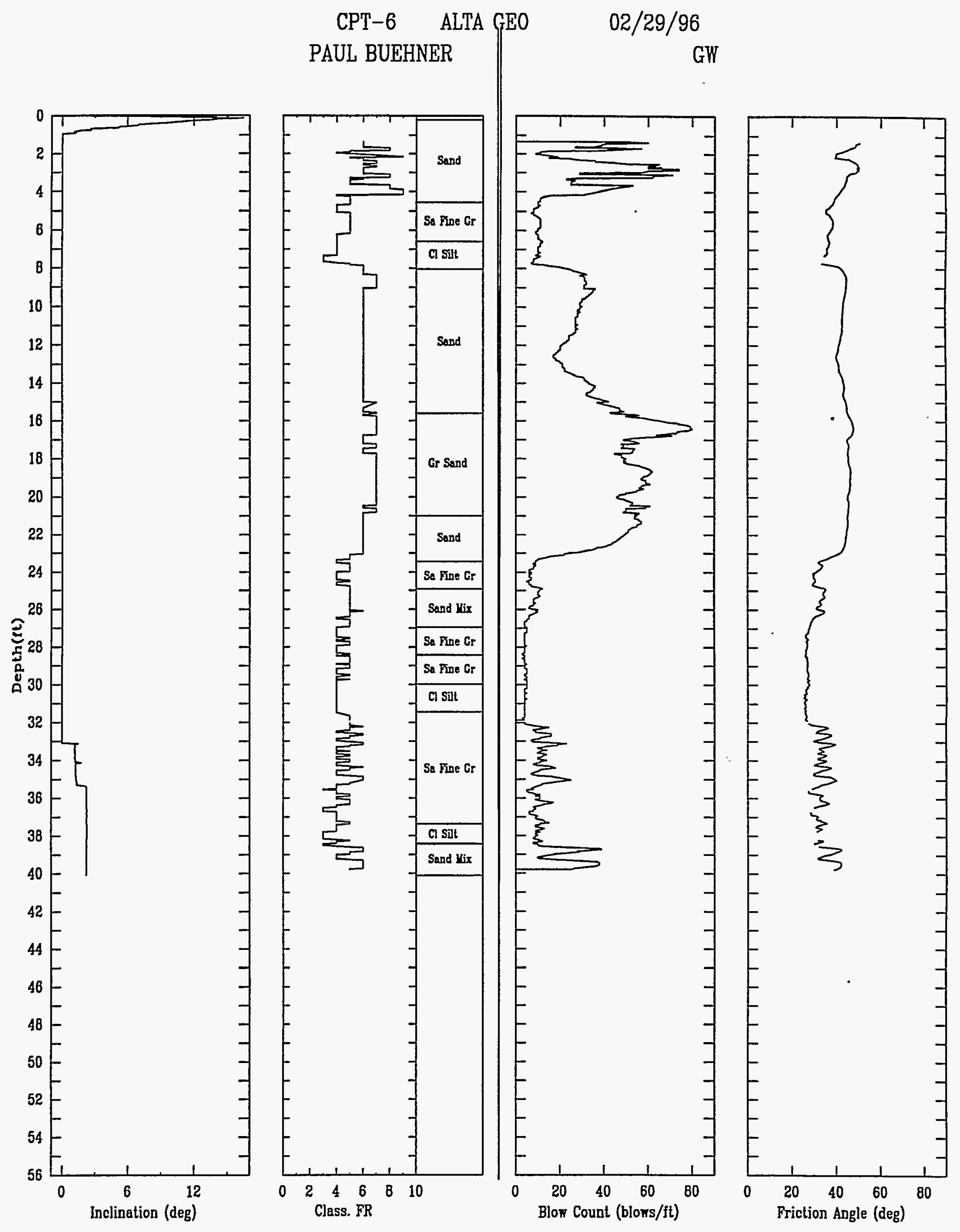


APPLIED RESEARCH ASSOCIATES INC.

New England Division

Data Acquisition System

Version 6.00

Pore Pressure Dissipation Test

Test Id : CPT-6

Depth $=\quad 15 . \mathrm{ft}$
Filename : AZ9F603P.015

Total Test Duration

8. minutes_

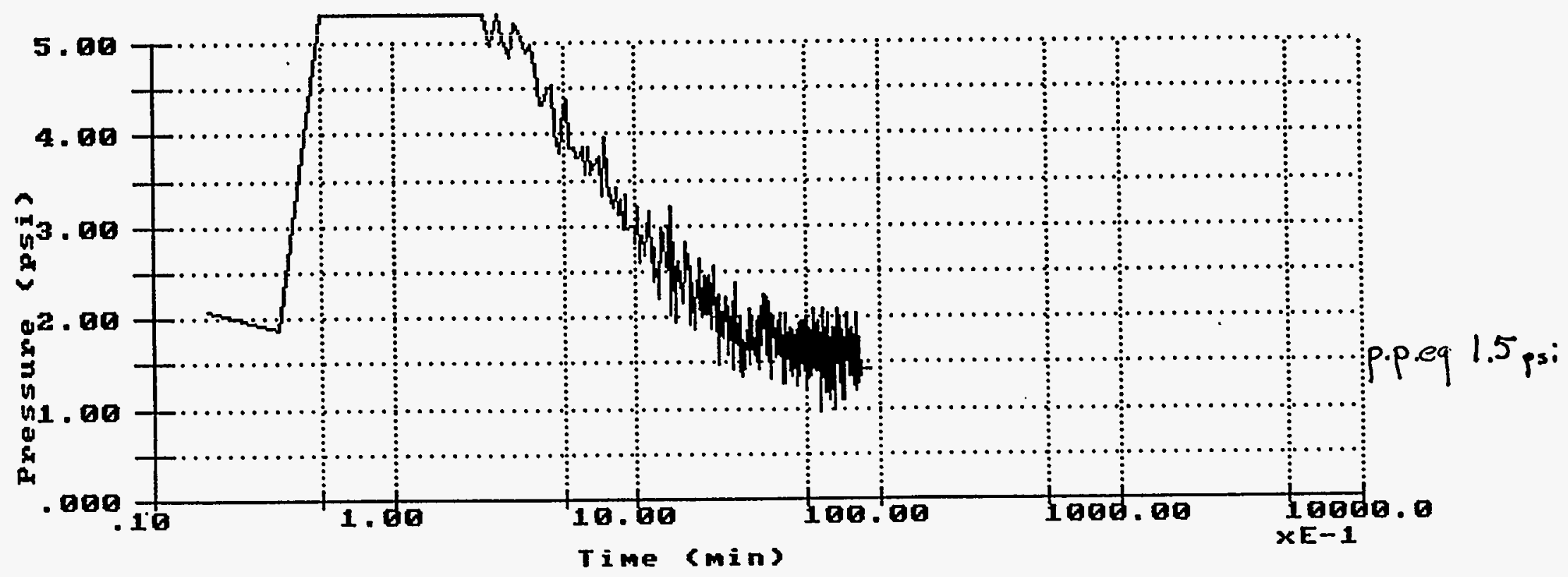


APPLIED RESEARCH ASSOCIATES INC.

\author{
New England Division \\ Data Acquisition System \\ Version 6.00
}

Pore Pressure Dissipation Test

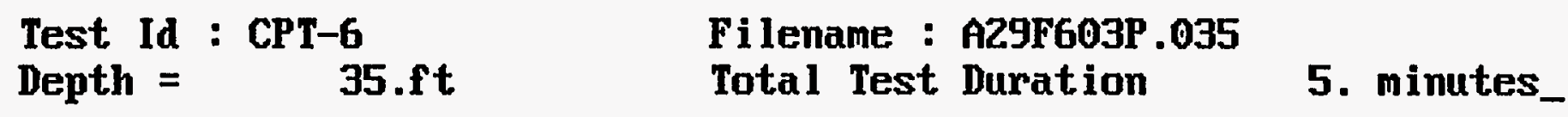

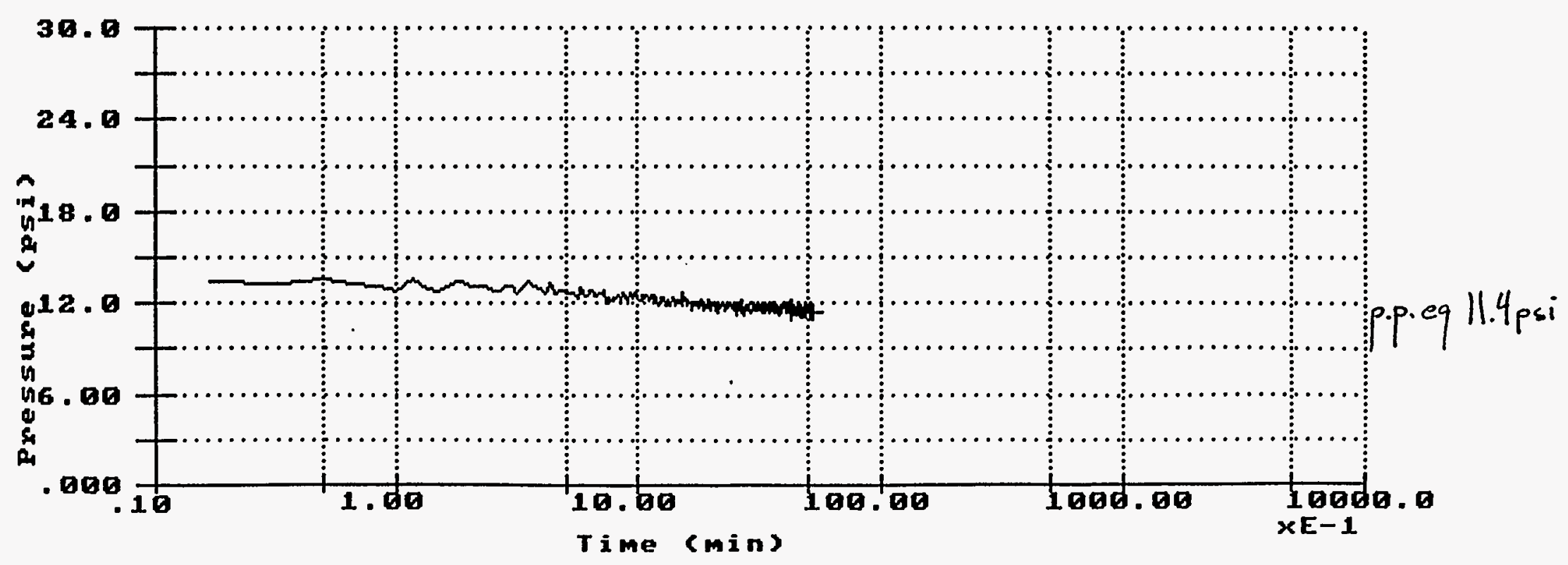


CPT-10 ALTA GE0

COUNTY FIELD

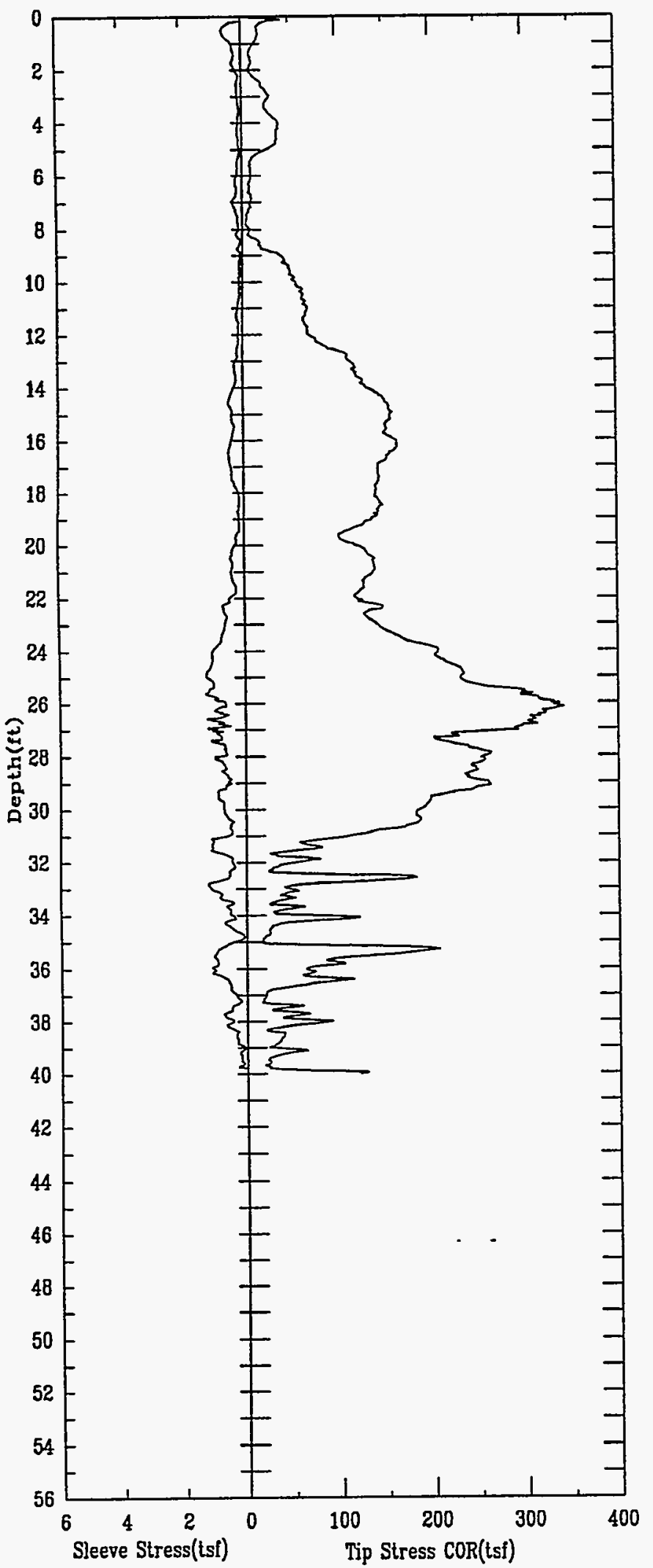

03/01/96

GW
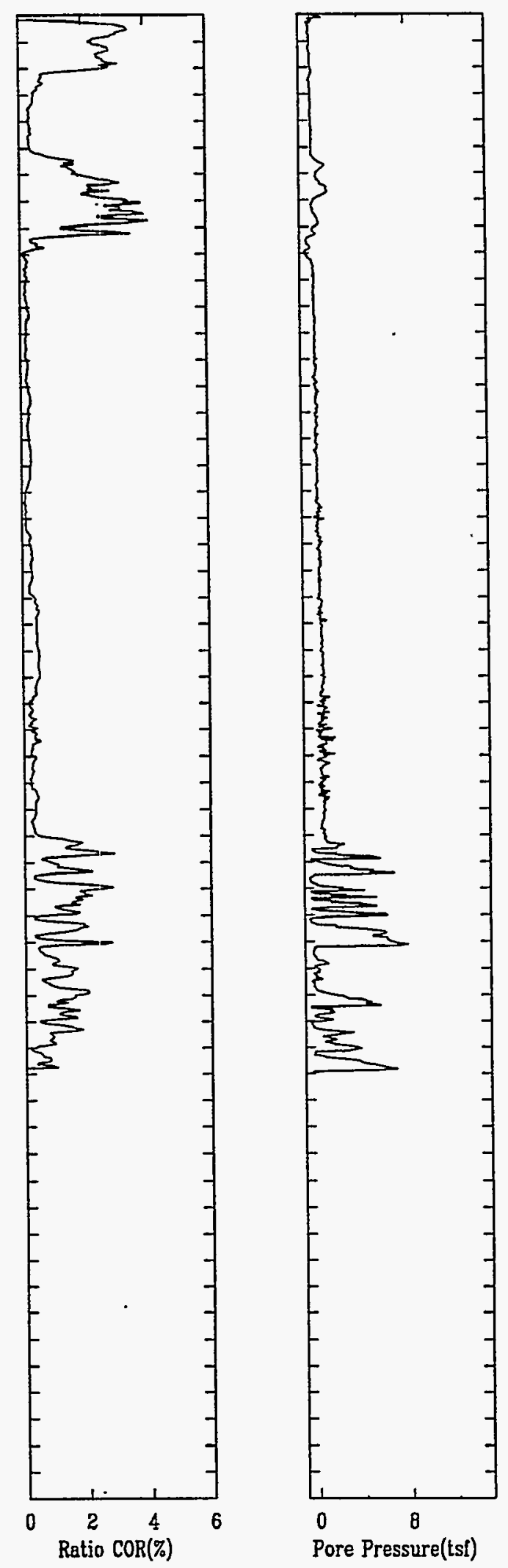


\section{APPLIED RESEARCH ASSOCIATES INC.}

New England Division

Data Acquisition System

Version 6.00

\section{Pore Pressure Dissipation Test}
Test Id : CPT-10
Depth $=$
Filename : A01M601P.018
Total Test Duration

5. minutes

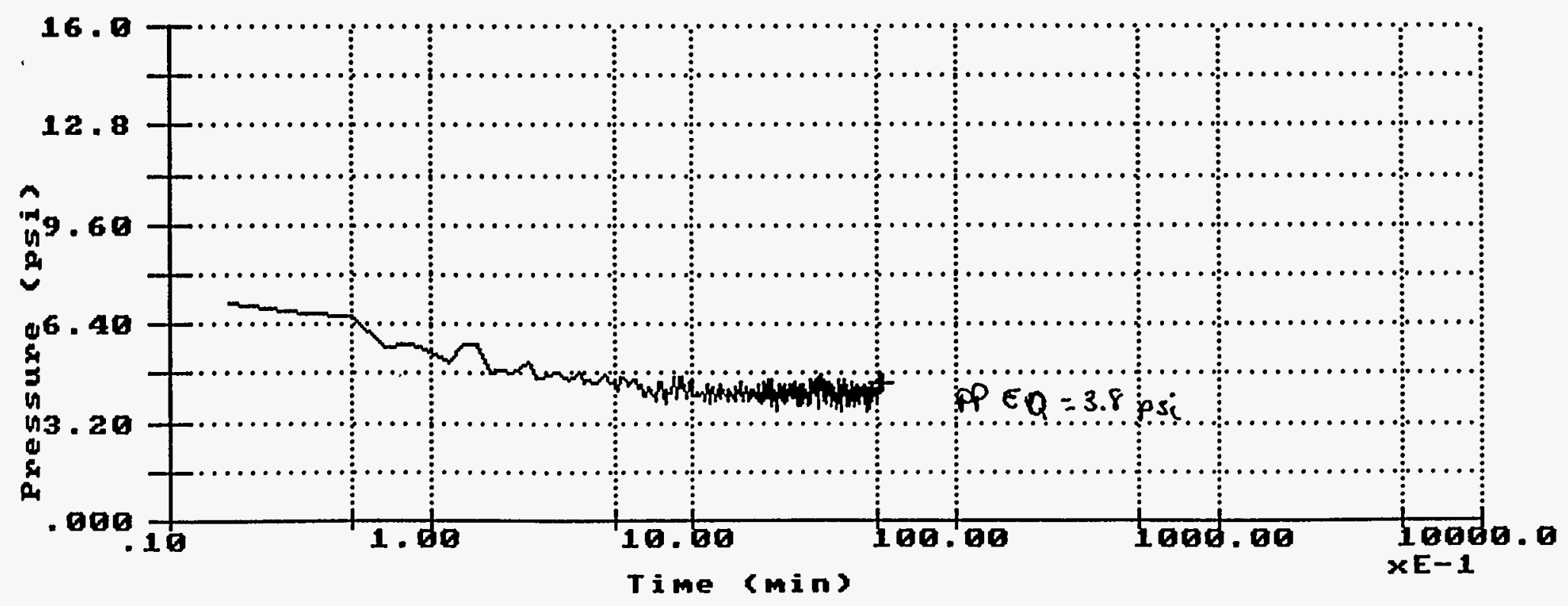




\section{CPT-10 ALTA GEO \\ 03/01/96 \\ COUNTY FIELD \\ GW}
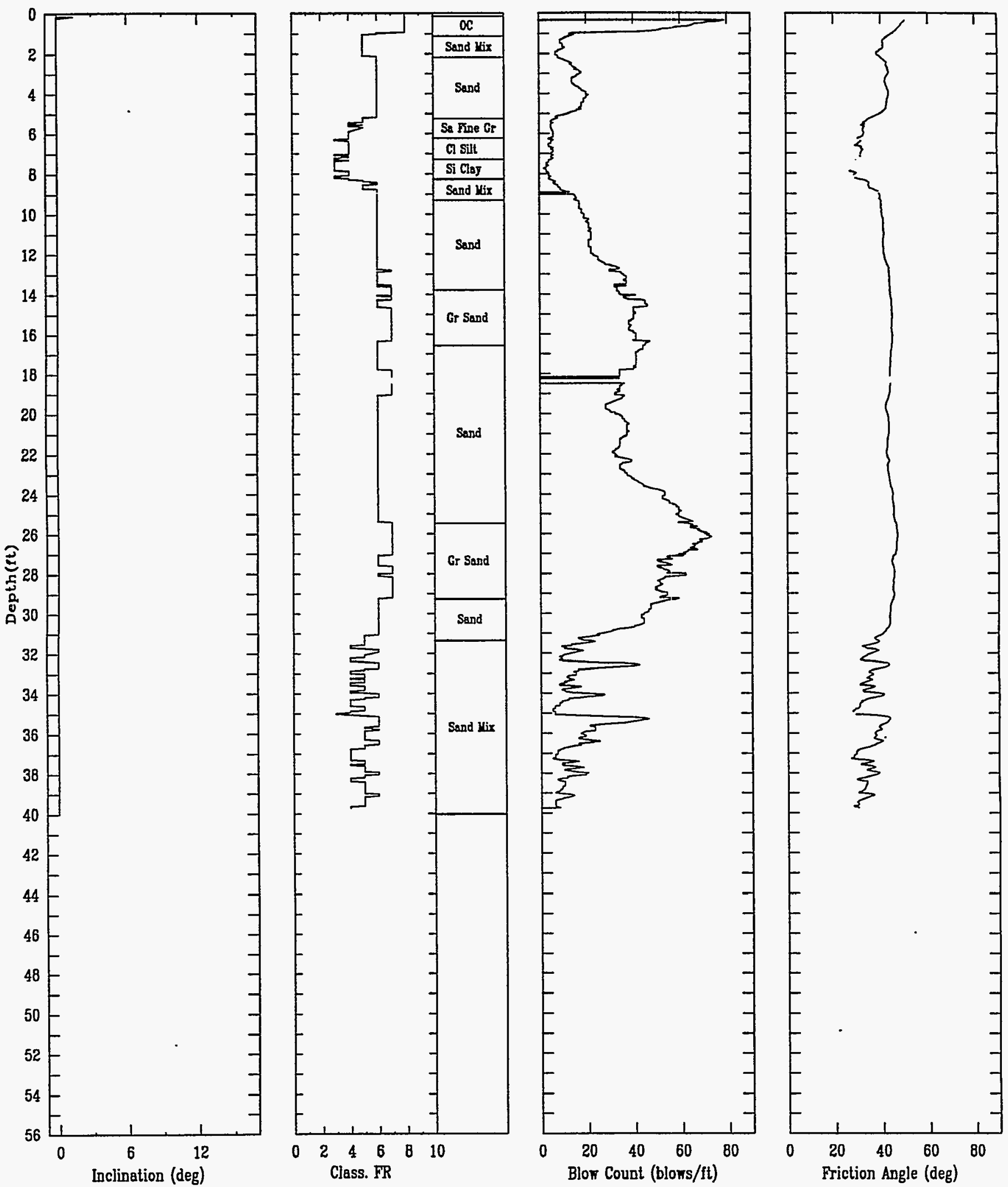


$\begin{array}{cr}\text { CPT-12 } & \text { ALTA GE0 } \\ \text { VITRO FIELD } & \text { GW }\end{array}$
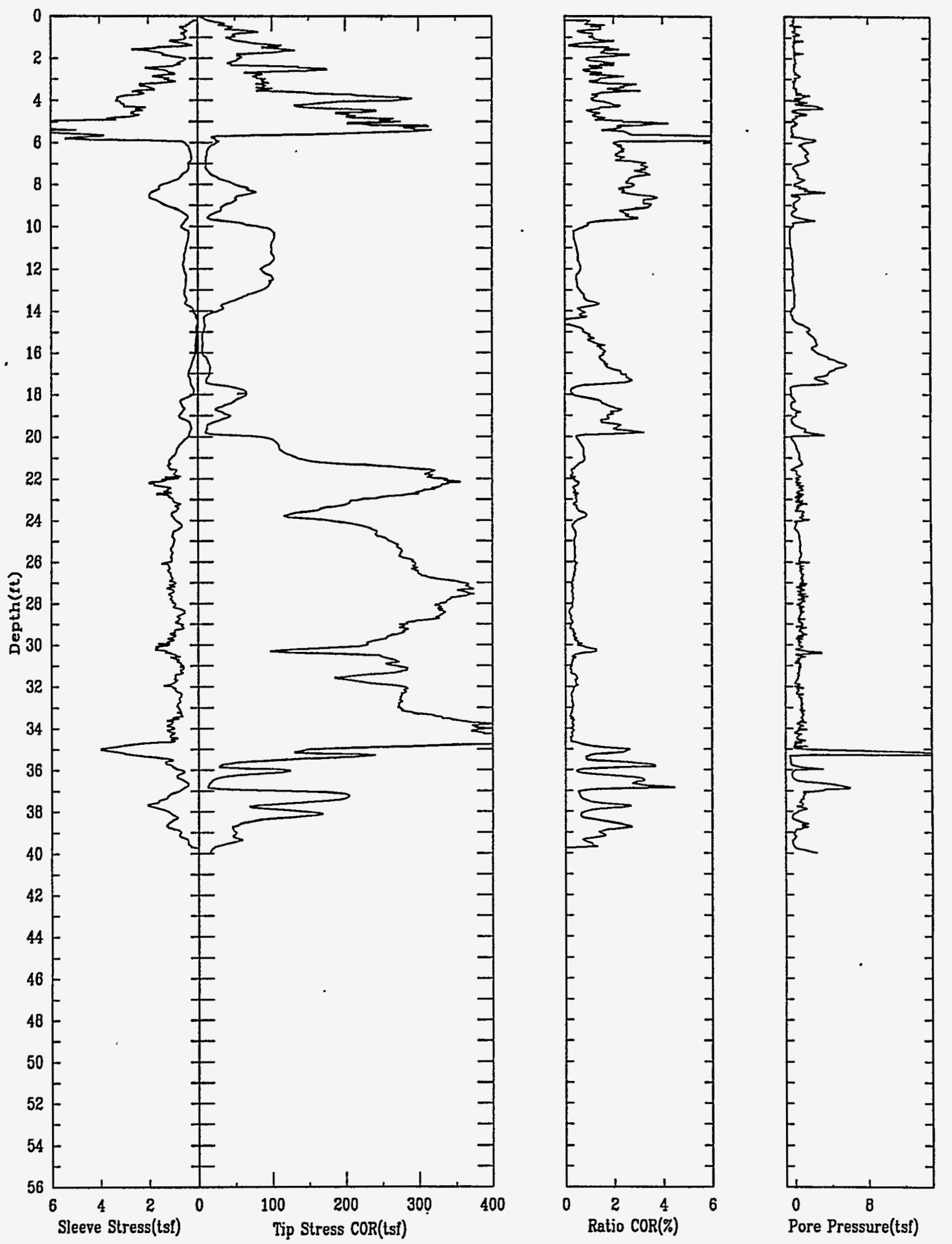
CPT-12 ALTA GEO 03/01/96

VITRO FIELD
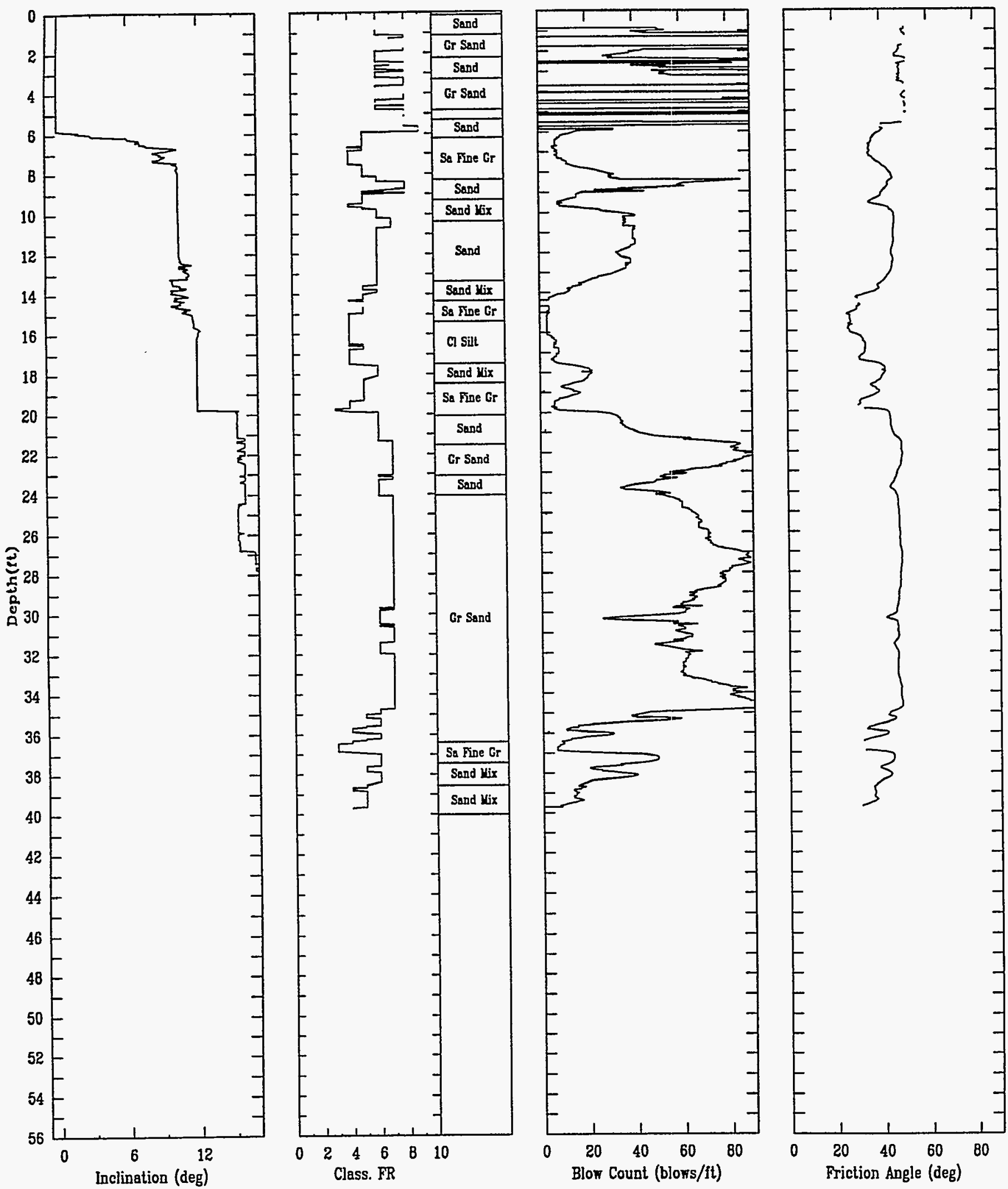


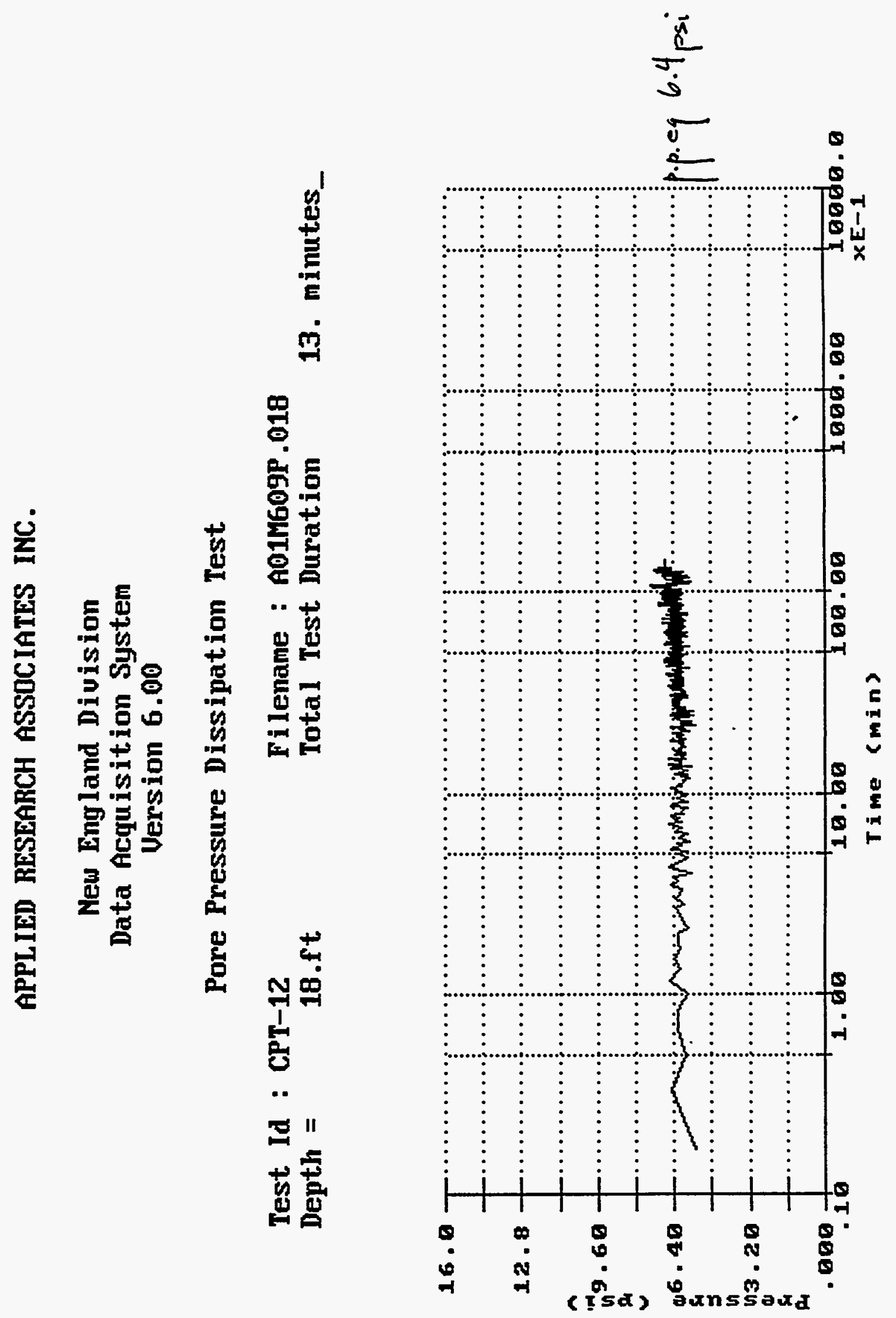


CPT-13 ALTA GEO

VALIEY FORKLIFT

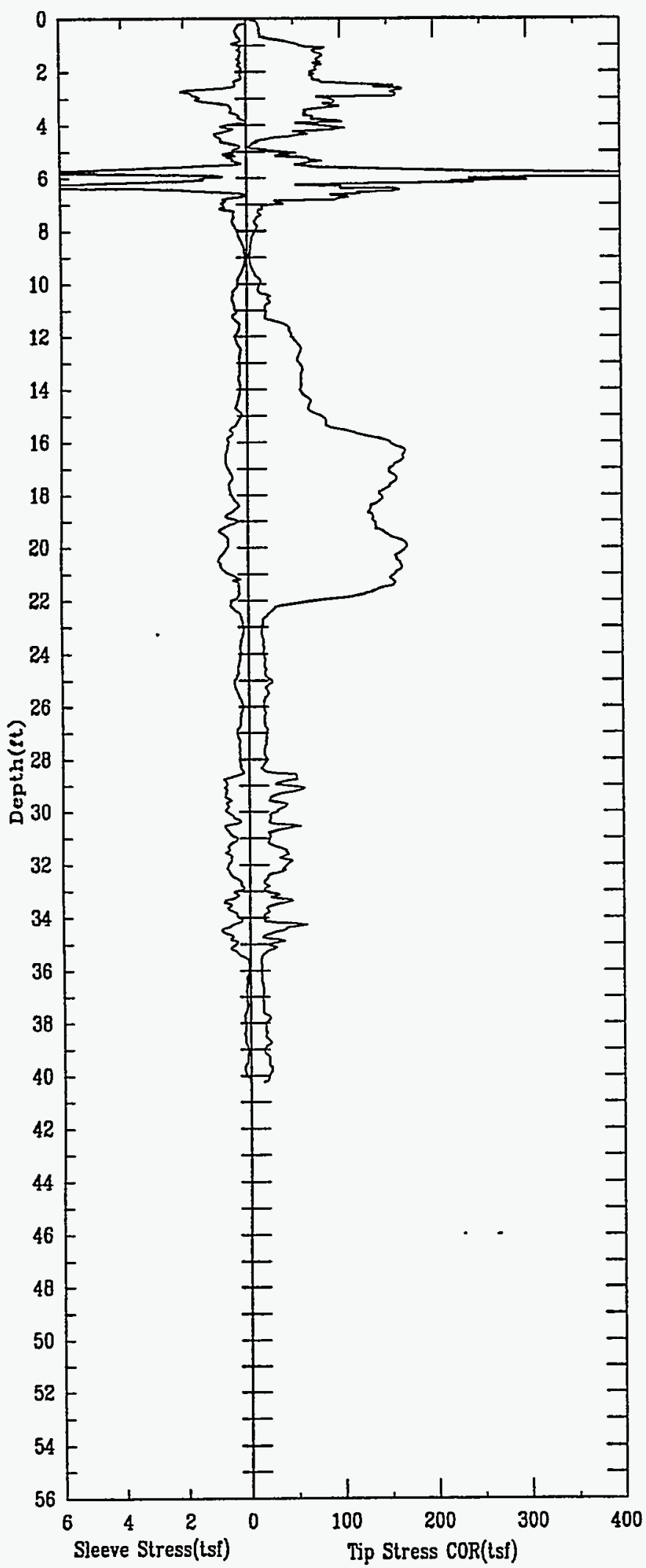

02/28/96

GW

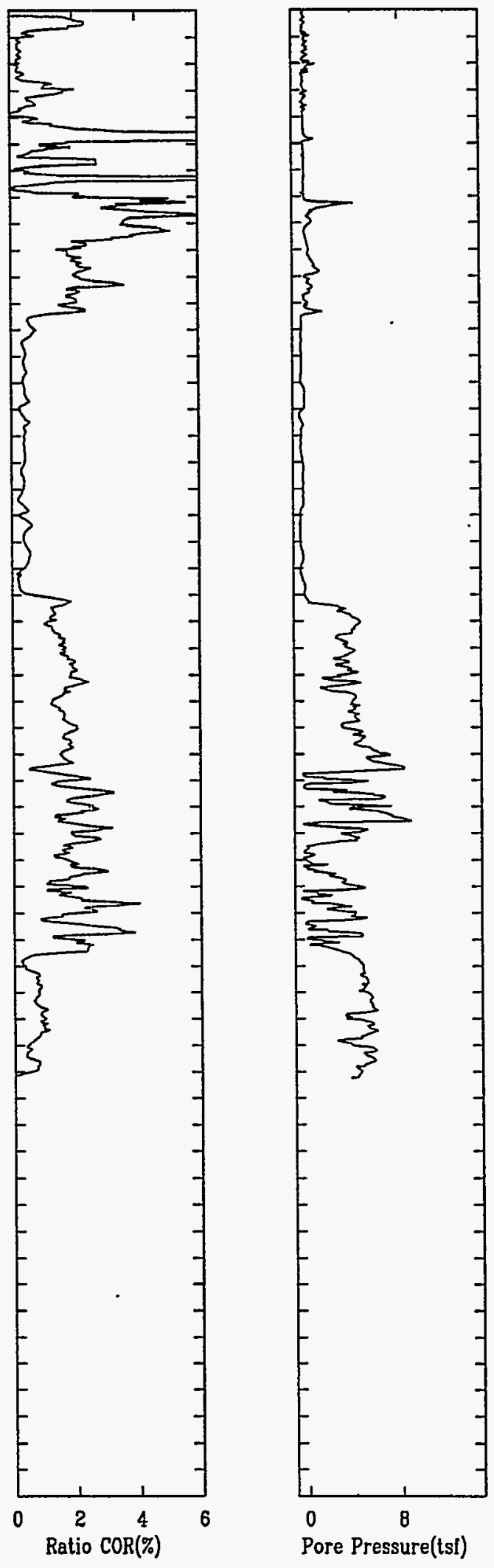

File A28F601.ECP 


$\begin{array}{crr}\text { CPT-13 } & \text { ALTA GEO } & 02 / 28 / 96 \\ \text { VALLEY FORKLIFT } & \text { GW }\end{array}$
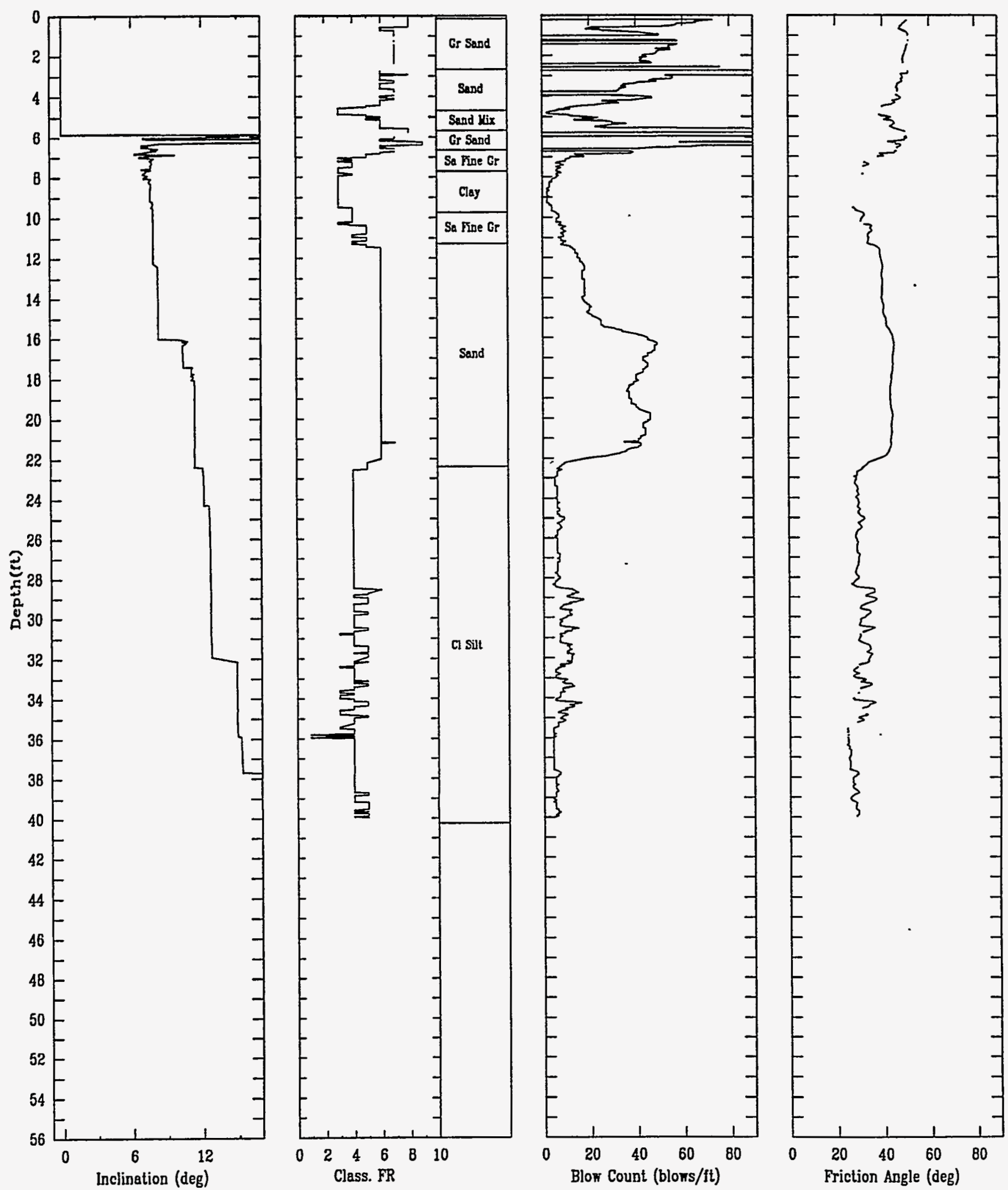


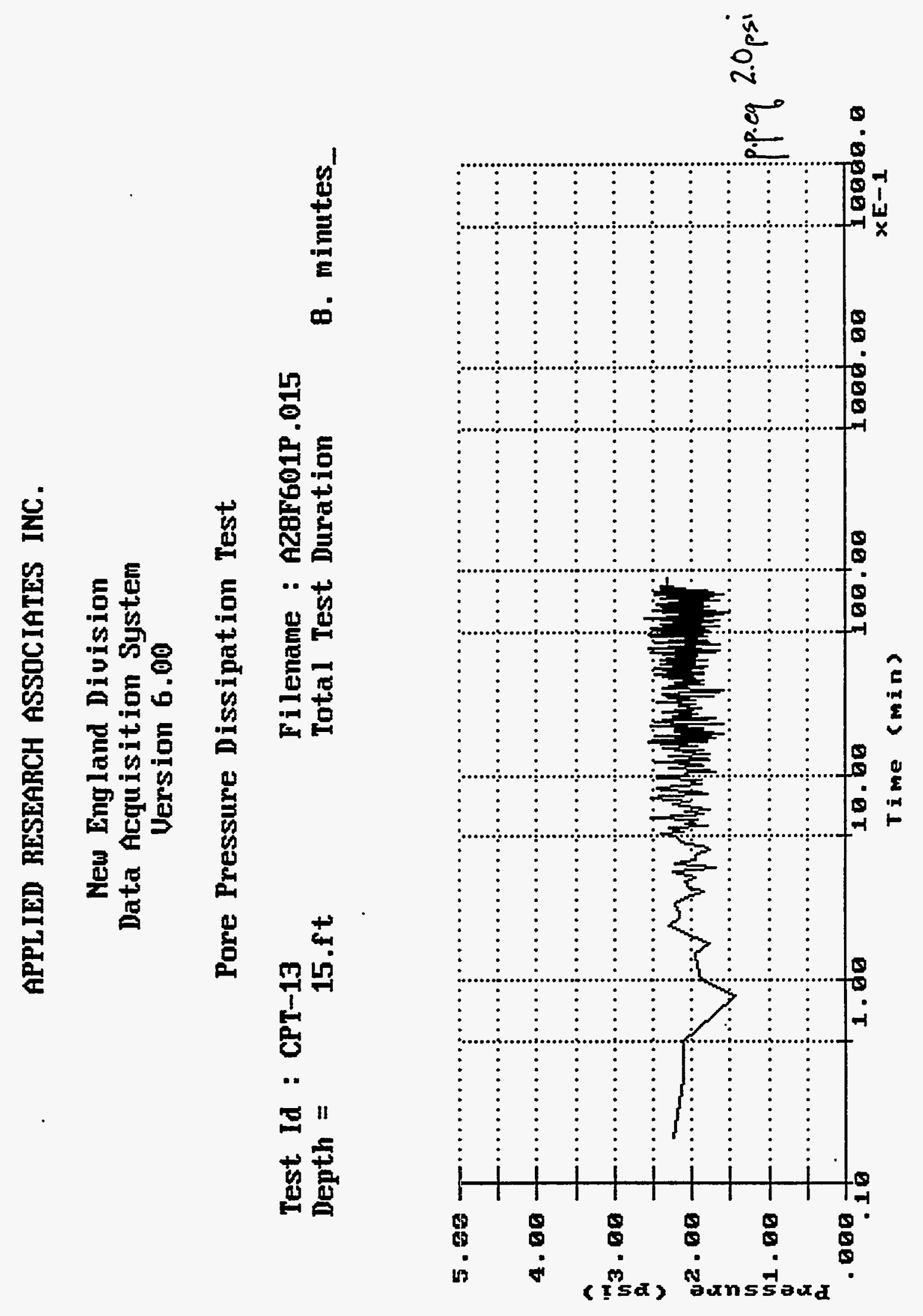




$\begin{array}{cr}\text { CPT-14 ALTA GEO } & 02 / 29 / 96 \\ \text { CONSTRUCTION OFFICE } & \text { GW }\end{array}$
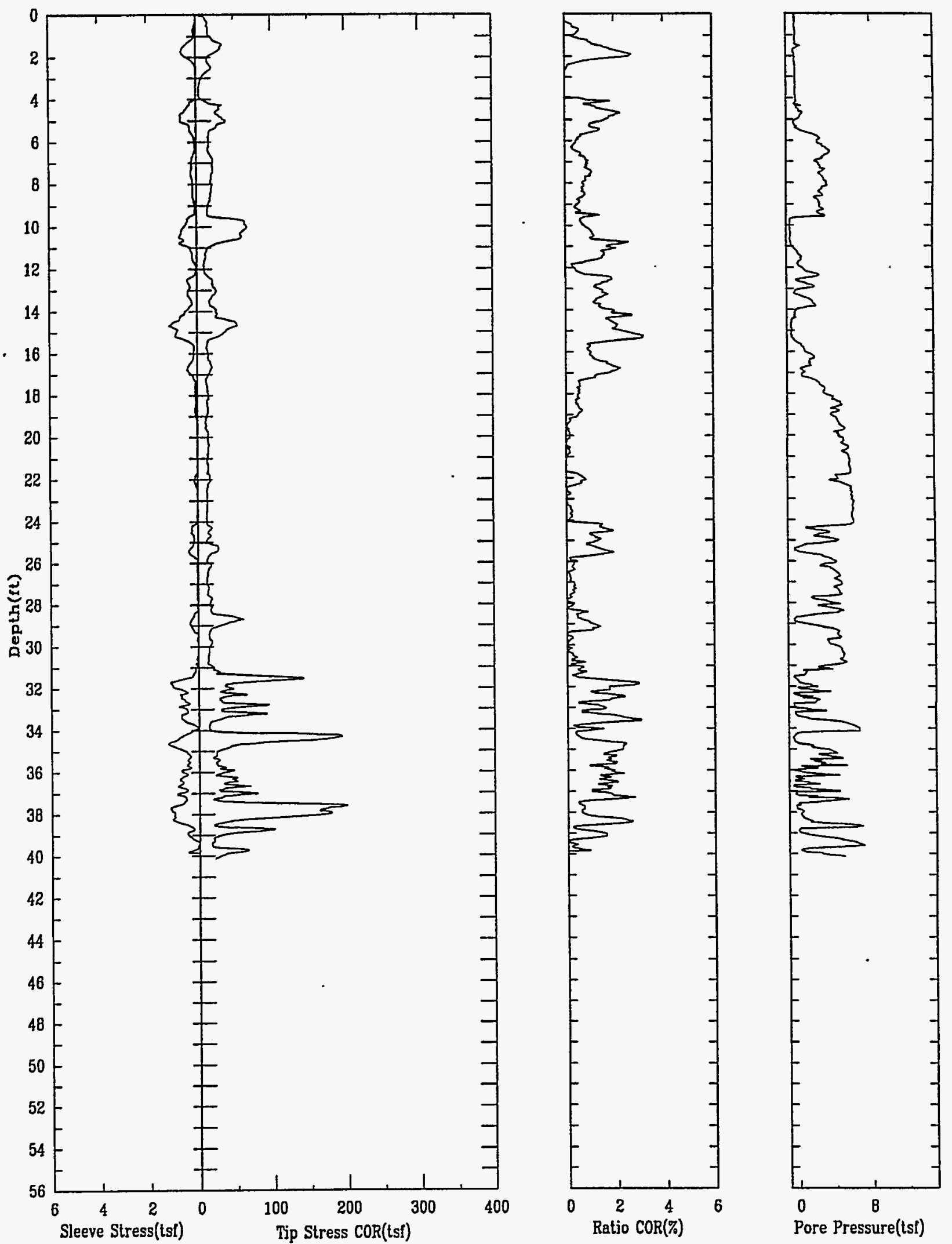

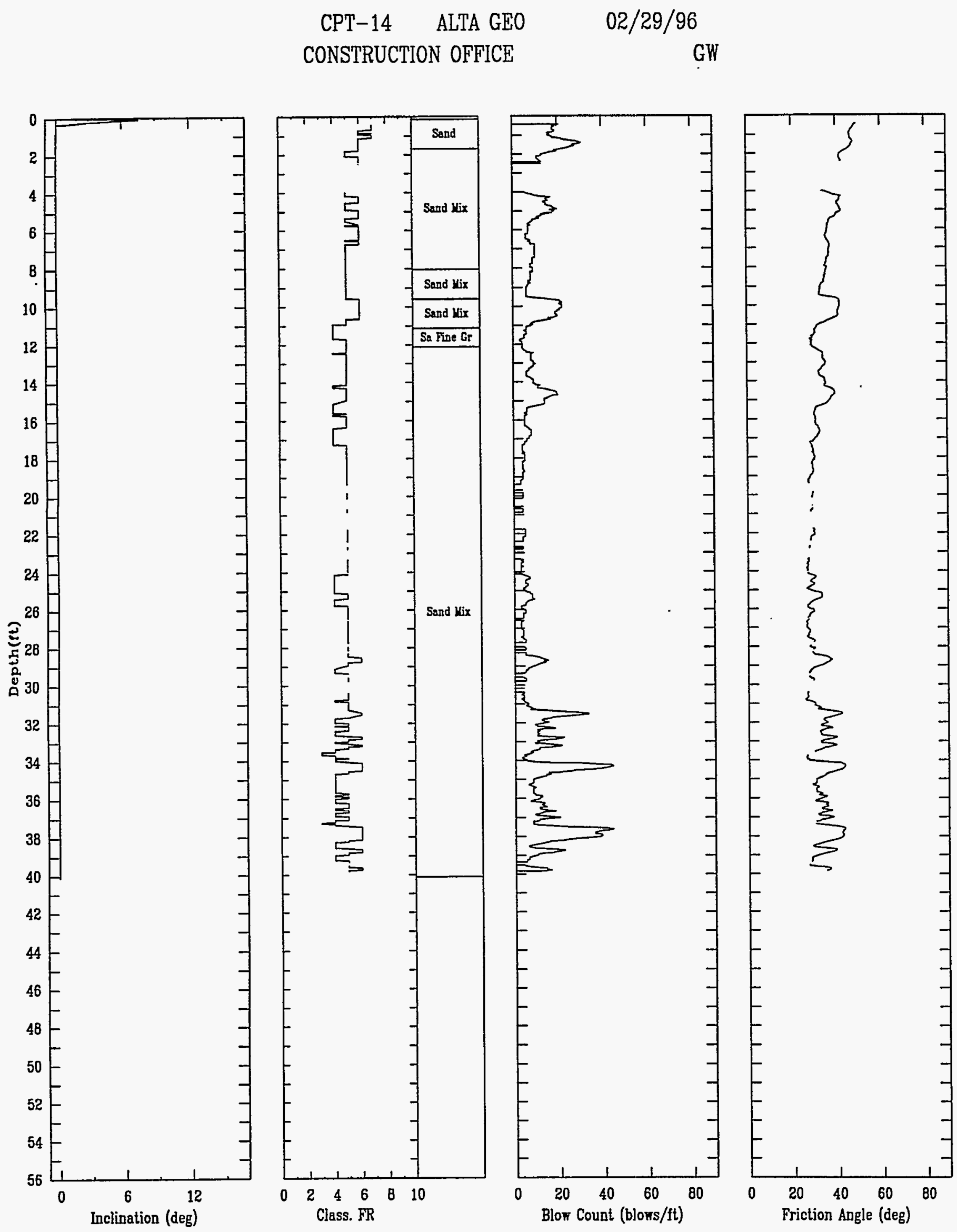

Pile A29F601.ECP 


\section{APPLIED RESEARCH ASSOCIATES INC.}

New England Division

Data Acquisition System

Version 6.00

Pore Pressure Dissipation Test

Test Id : CPT-14

Depth $=$ 15.ft
Filename : A29F601P.015

Total Test Duration

21. minutes

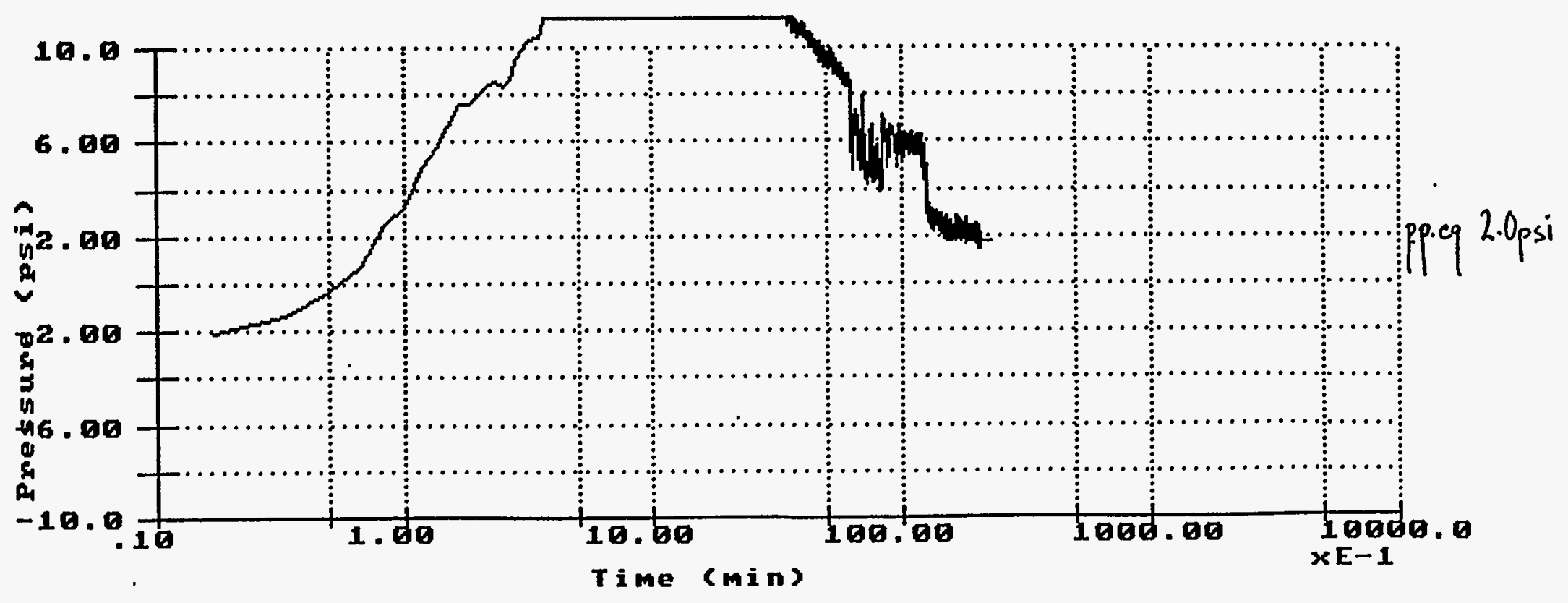




\title{
APPLIED RESEARCH ASSOCIATES INC.
}

\author{
New England Division \\ Data Acquisition System \\ Uersion 6.00
}

\section{Pore Pressure Dissipation Test}
Test Id : CPT-14
Depth $=\quad 32 . f t$
Fi lename : A29F601P.032
Total Test Duration
6. minutes

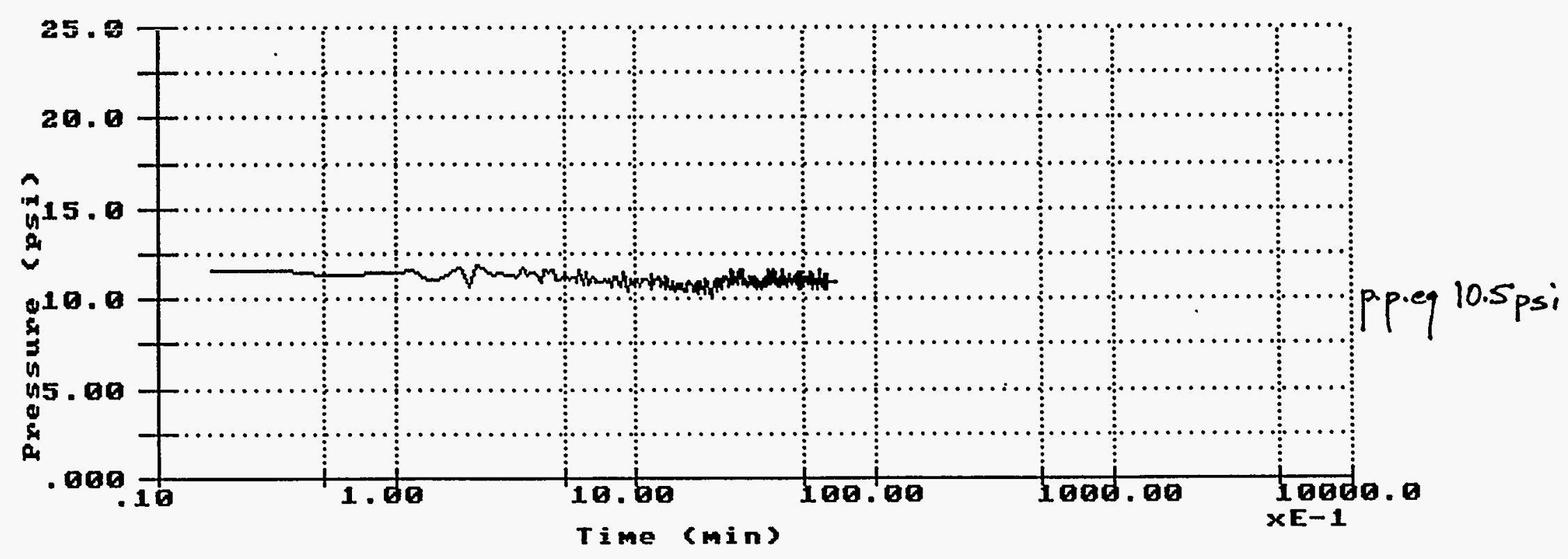




\section{CPT-15 ALTA GE0 \\ SW CORNER COUNTY PRISON \\ 03/01/96 \\ GW}
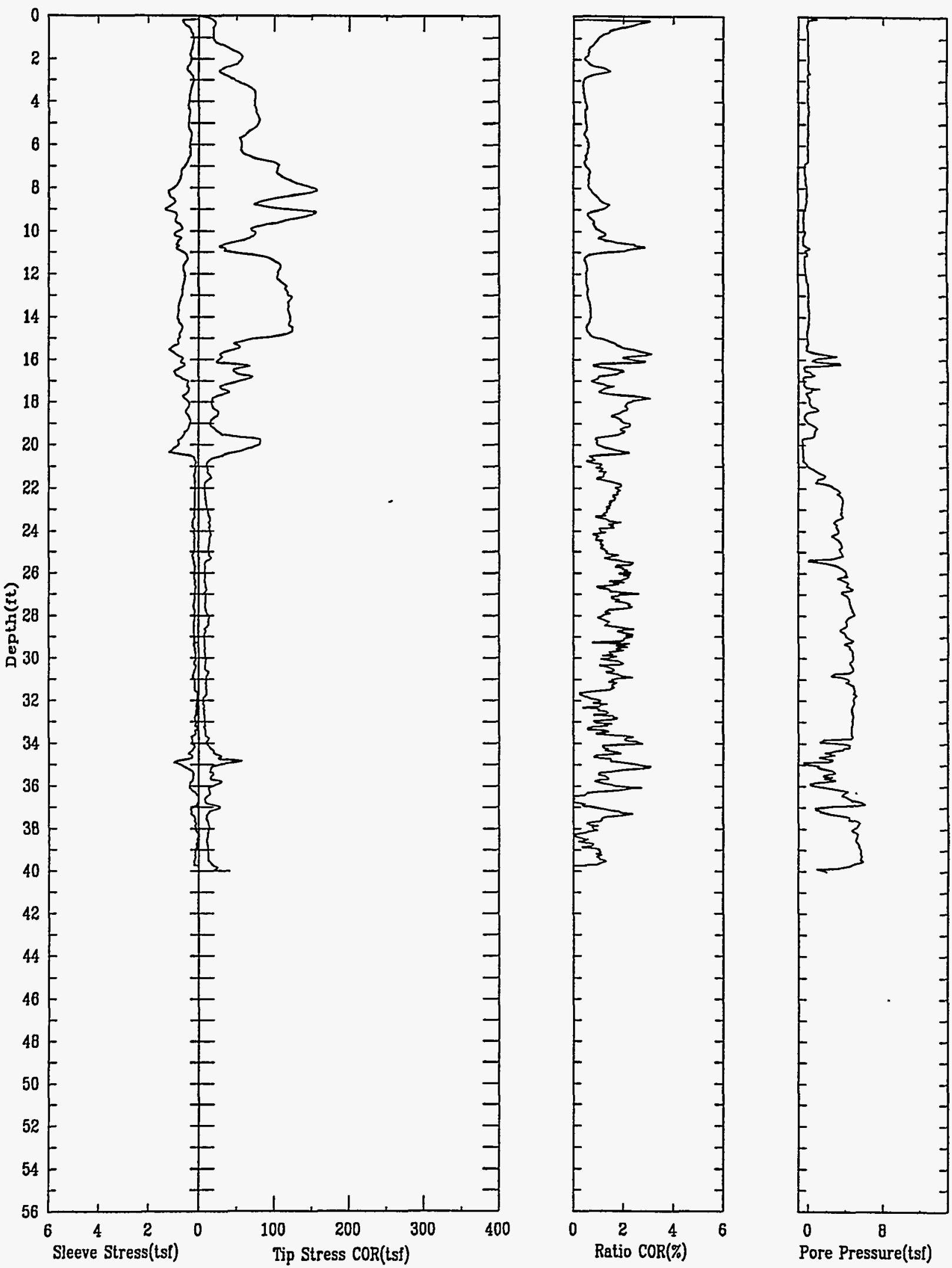


\section{CPT-15 ALTA GEO 03/01/96 \\ SW CORNER COUNTY PRISON}

GW
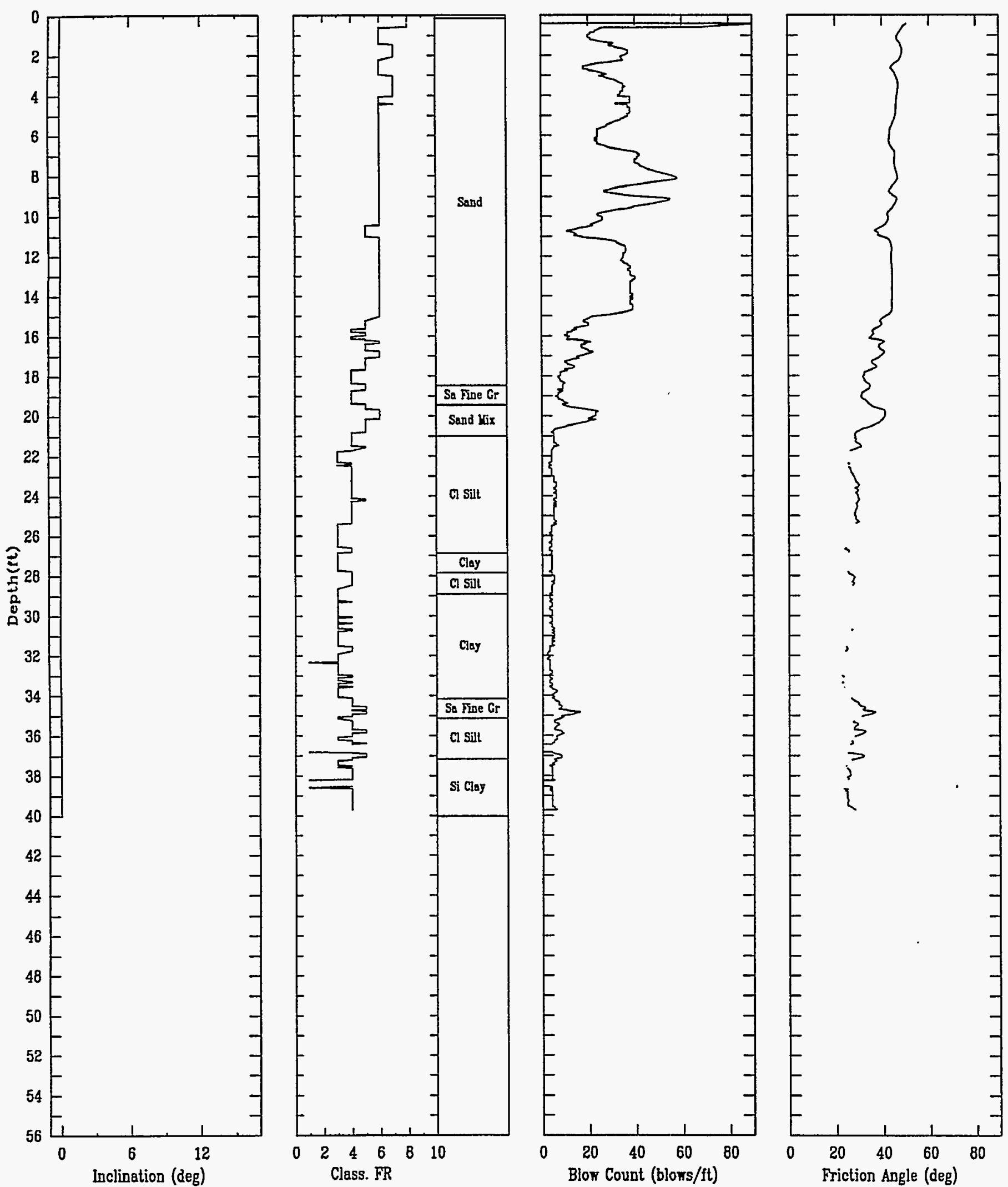
APPLIED RESEARCH ASSOCIATES INC.

New England Division

Data Acquisition System

Version 6.00

Pore Pressure Dissipation Test

Test Id : CPT-15

Depth $=15 . \mathrm{ft}$
Fi lename : A01M603P.015

Total Test Duration
16. minutes

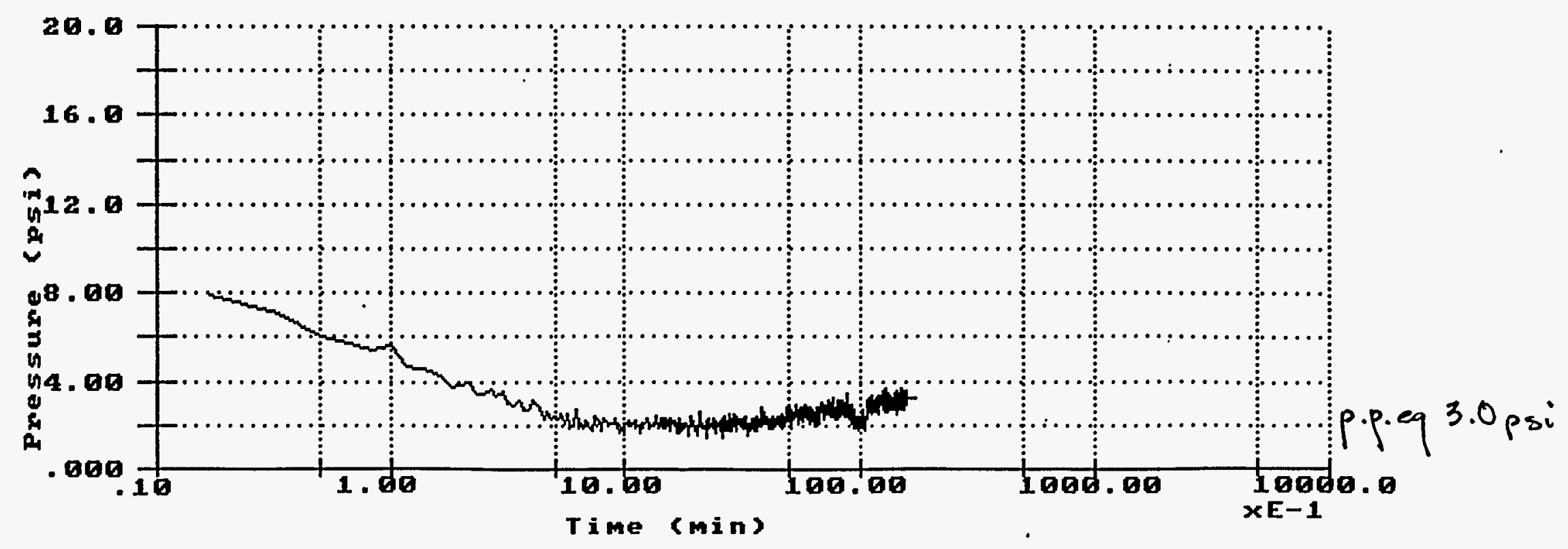


CPT-16 ALTA GEO

SE CORNER COUNTY PRISON
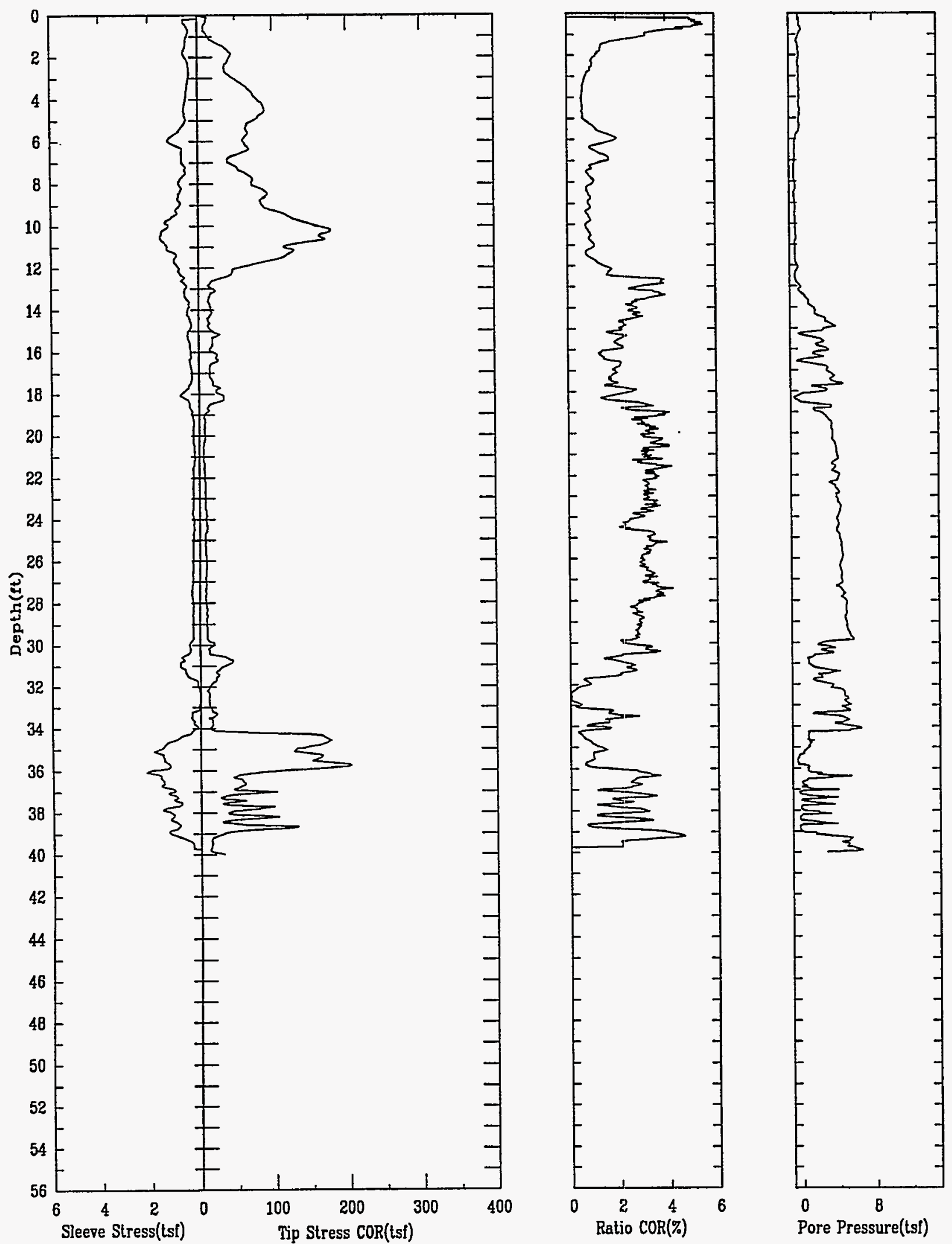


\section{CPT-16 ALTA GEO 03/01/96 \\ SE CORNER COUNTY PRISON GW}
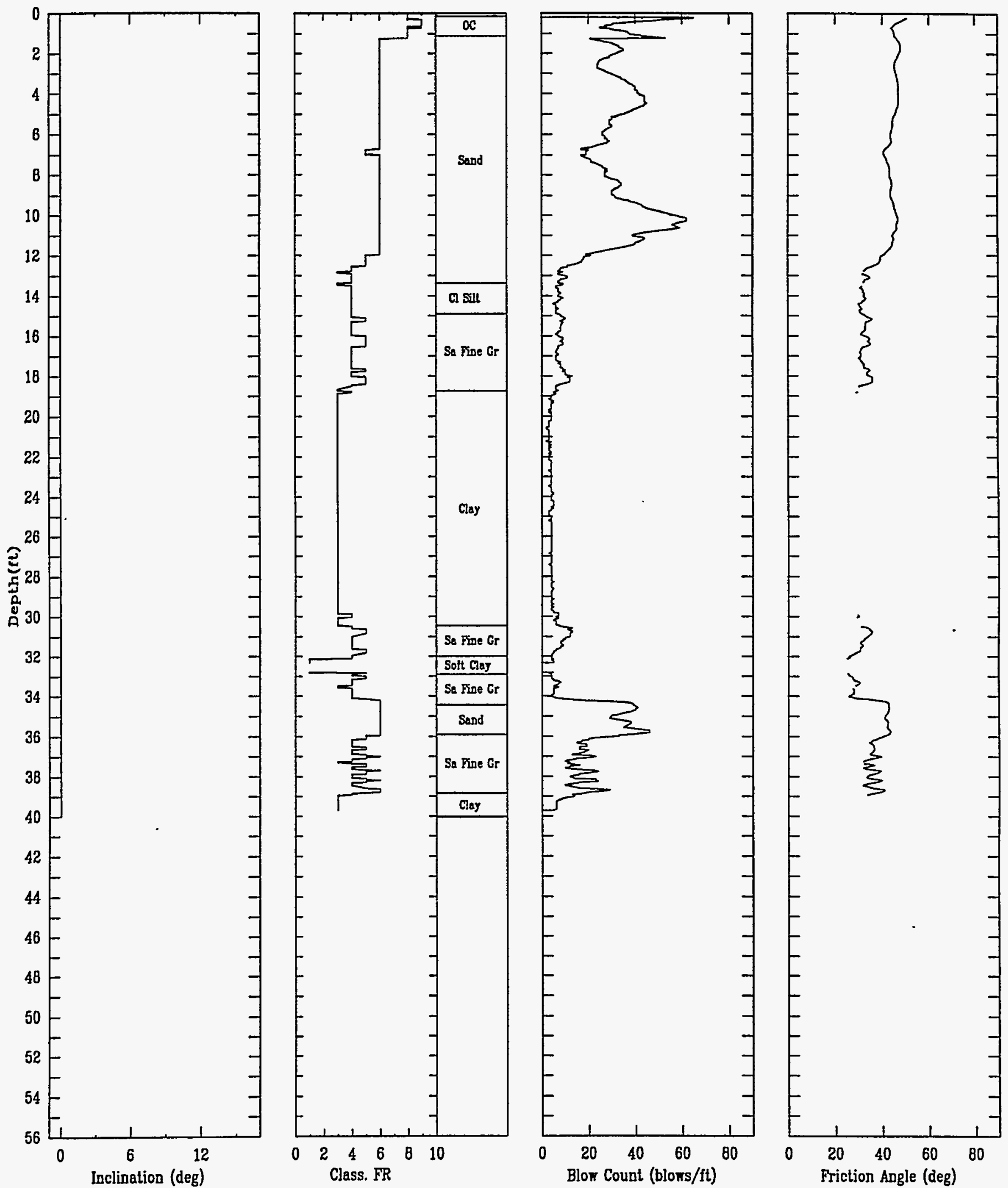
APPLIED RESEARCH ASSOCIATES INC.

New England Division

Data Acquisition System

Version 6.00

Pore Pressure Dissipation Test

Test Id : CPT-16

Depth $=35.589 \mathrm{ft}$
Filename : A01M605

Total Test Duration 9.100 minutes_

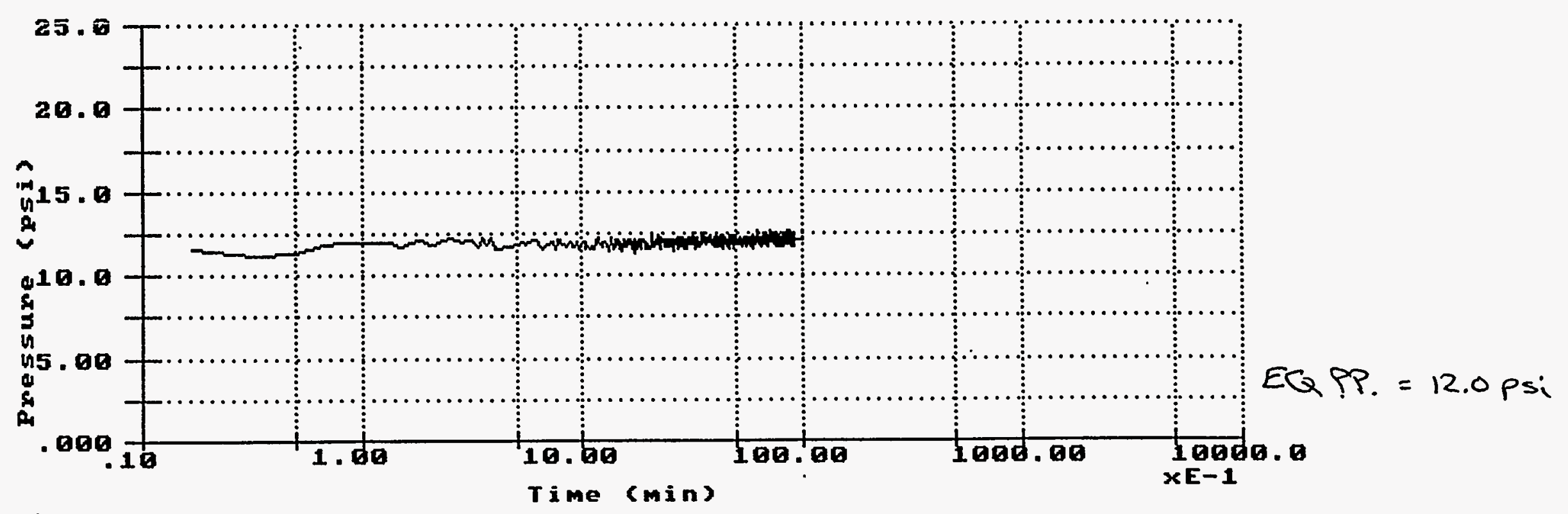


Survey Results, Salt Lake City HydroPunch Field Effort

\begin{tabular}{|c|c|c|c|c|c|c|c|c|c|c|}
\hline Sta. & Point & Description & Rod & & & $\begin{array}{l}\text { Azimuth } \\
\text { degrees }\end{array}$ & $\begin{array}{l}\text { Distance } \\
\text { feet }\end{array}$ & Easting & Northing & $\begin{array}{l}\text { Elevation } \\
\text { feet }\end{array}$ \\
\hline \multirow[t]{4}{*}{$\mathbf{L}$} & & Station L & & & & & & $1,839,654$ & 817,608 & 4241.7 \\
\hline & L1 & Well 134 PVC casing & -2.19 & 3.07 & 1.32 & 170 & 175[ & $1,839,684$ & 817,436 & 4239.5 \\
\hline & L2 & $900 \mathrm{~W}$ bridge - pt A1 & -4.51 & 4.92 & 4.10 & 310 & 82 & $1,839,591$ & 817,661 & 4237.2 \\
\hline & L3 & WL in Mill Croek at L2/A1 & $-13.89 n a$ & $n$ & & 310 & & $1,839,591$ & 817,661 & 4227.8 \\
\hline \multirow[t]{4}{*}{ A } & & Station A & & & & & & $1,838,930$ & 817,719 & 4239.8 \\
\hline & A1 & $900 \mathrm{~W}$ bridge - pt L2 & -2.64 & 5.96 & 2.64 & 95 & 664 & $1,839,591$ & 817,661 & 4237.2 \\
\hline & A2 & SE corner of RR bridge & -3.94 & 4.86 & 3.02 & 280 & 184 & $1,838,748$ & 817,751 & 4235.9 \\
\hline & A4 & CPT-6 & -5.89 & 6.85 & 4.91 & 241 & 194 & $1,838,760$ & 817,625 & 4233.9 \\
\hline \multirow[t]{5}{*}{ L } & & STA M & & & & & & $1,838,608$ & 817.726 & 4240.4 \\
\hline & M1 & Backshot to $A 2$ & -4.53 & 5.25 & 3.82 & 12 & 143 & $1,838,748$ & 817,751 & 4235.9 \\
\hline & M2 & WL Mill Creek at RR bridge & -12.8 & 5.76 & 5.43 & 80 & 33 & $1,838,640$ & 817,732 & 4227.6 \\
\hline & M3 & WP-6 top of PVC casing & -6.41 na & $n$ & & na & & $1,838,760$ & 817,625 & 4234.0 \\
\hline & & WL WP-6 & -6.13 na & ne & & na & & $1,838,760$ & 817,625 & 4227.9 \\
\hline \multirow[t]{6}{*}{ D } & & Station D & & & & & & $1,838,391$ & 817,925 & 4242.6 \\
\hline & D1 & Backshot to A2 & -6.67 & 8.67 & 4.69 & 116 & 398 & $1,838,748$ & 817,751 & 4235.9 \\
\hline & D2 & backshot to $\mathrm{C} 2$ & -5.02 & 8.76 & 1.3 & 182 & 746 & $1,838,365$ & 817,180 & 4237.5 \\
\hline & D3 & RR behind Smith's & -8.72 & 11.4 & 6 & 36 & 540 & $1,838,708$ & 818,362 & 4233.8 \\
\hline & D4 & WL, Mill Creek, by STA D & -15.18 & 15.43 & 14.91 & 202 & 52 & $1,838,371$ & 817,877 & 4227.4 \\
\hline & D5 & WL confluence Jordan - Mill Cks & -15.2 & 15.2 & 12.3 & 297 & 580 & $1,837,874$ & 818,188 & 4227.4 \\
\hline \multirow[t]{5}{*}{ E } & & STAE & & & & & & $1,838,583$ & 818,951 & 4237.2 \\
\hline & E1 & Backshot to D3 & -3.4 & 6.42 & 0.4 & 168 & 602 & $1,838,708$ & 818,362 & 4233.8 \\
\hline & E2 & Levy, NW corner Condie Prop & -1.89 & 4.66 & 1.89 & 257 & 554 & $1,838,043$ & 818,826 & 4235.3 \\
\hline & E3 & RR, by NE corner Condie Prop & -6.09 & 6.59 & 5.58 & 75 & 101 & $1,838,681$ & 818,977 & 4231.1 \\
\hline & E4 & CPT-10 (approximate) & -4.91 na & $n$ & & 30 & 270 & $1,838,718$ & 819,185 & 4232.3 \\
\hline \multirow[t]{5}{*}{$\mathbf{P}$} & & Station P & & & & & & $1,838,557$ & 818,928 & 4236.9 \\
\hline & P2 & Backshot to pt D3 & -3.02 & 5.95 & 3.02 & 165 & 586 & $1,838,708$ & 818,362 & 4233.8 \\
\hline & P1 & WP-10 top of PVC casing & -4.75 & 4.855 & 4.64 & 30 & 22 & $1,838,567$ & 818,947 & 4232.1 \\
\hline & P3 & Low spot on floodplain & -7.16 & 7.7 & 6.64 & 191 & 106 & $1,838,536$ & 818,824 & 4229.7 \\
\hline & & WL WP-10 & -3.55 na & $n$ & & na & & $1,838,536$ & 818,824 & 4228.6 \\
\hline & & Station C & & & & & & $1,838,043$ & 816,587 & 4241.7 \\
\hline & C2 & Turn Pt $=\mathrm{D} 2$ & -4.18 & 7.55 & 4.18 & 28.5 & 674 & $1,838,365$ & 817,180 & 4237.5 \\
\hline
\end{tabular}


Survey Results, Salt Lake City HydroPunch Field Effort

C1 Backshot to B3

C3 WL, Jordan River by CPT-4

C4 CPT-4

Station 0

01 Backshot to B3

03 WL WP-4 top of PVC riser

B

$\begin{array}{ll} & \text { Station B } \\ \text { B3 } & \text { Turnpoint }=\mathrm{C1} \\ \text { B1 } & \text { CPT-2 } \\ \text { B2 } & \text { Benchmark - manhole cover }\end{array}$

N

N2 backshot to pt B2

N1 WP-2 top of PVC

N3 WL WP-2 below top of PVC

\section{F2 MW 133 top PVC casing}

GL at MW 133

F3 CPT-1

F4 Woll 135 Top of PVC casing

Expected well 135

Error

F5 GL well 135

F6 Fence, west side of site

F7 CPT-12

G1 Backshot to F1

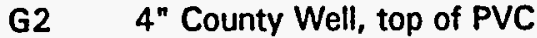

H

$\begin{array}{ll}\text { H1 } & \text { Backshot to G2 } \\ \text { H2 } & \text { CPT-14 }\end{array}$

H3 Turnpt

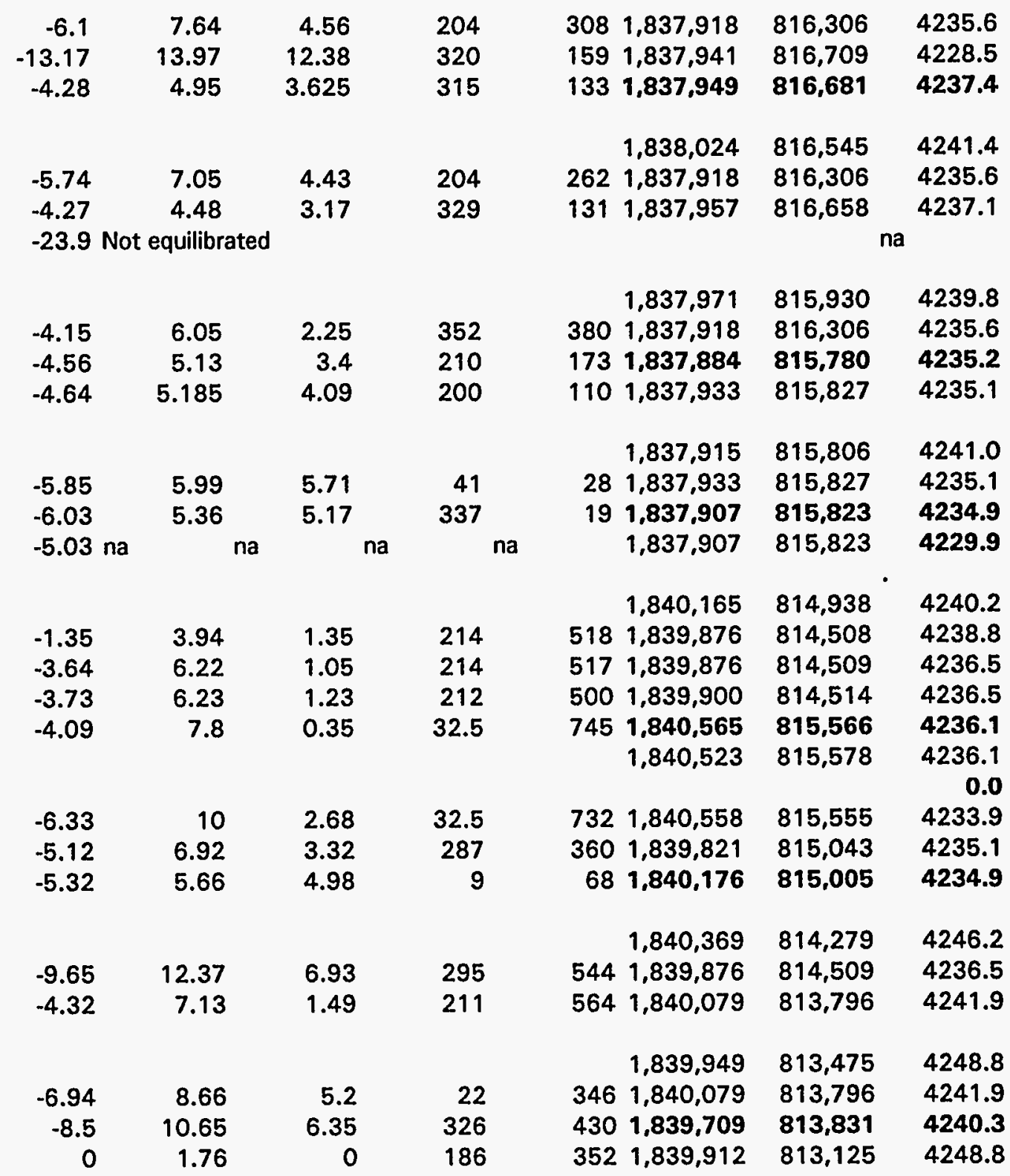


Survey Results, Salt Lake City HydroPunch Field Effort

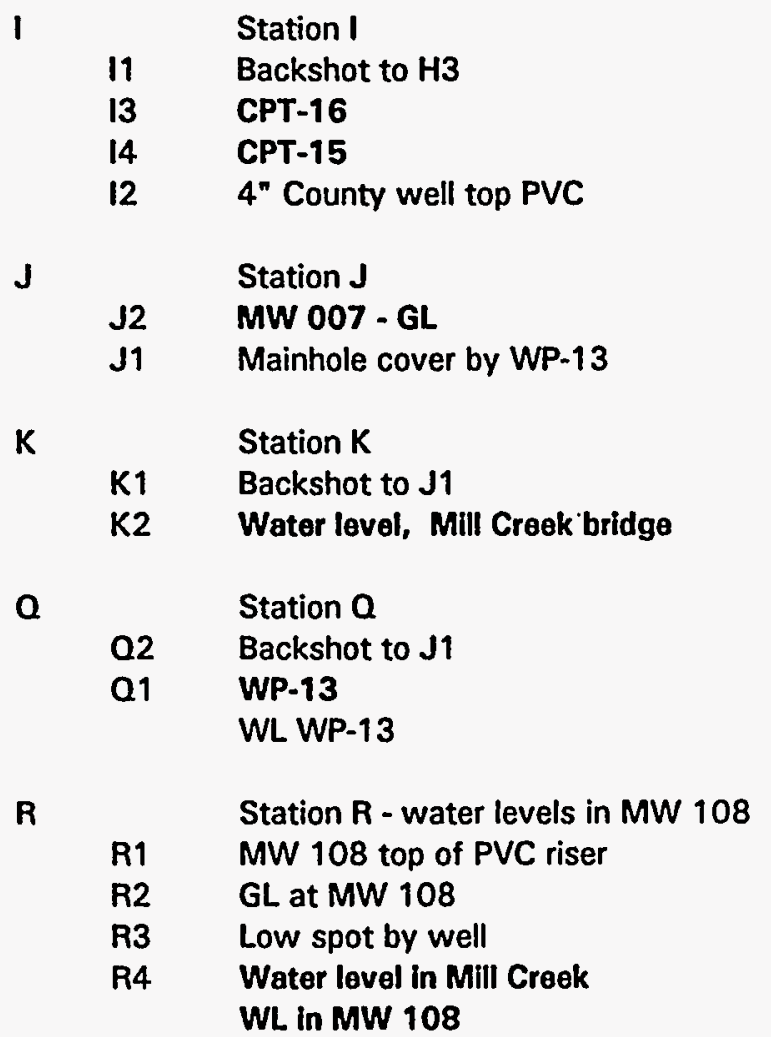

$\begin{array}{rrrrrrrr} & & & & 1,840,003 & 812,938 & 4254.6 \\ -5.76 & 6.81 & 4.73 & 334 & 208 & 1,839,912 & 813,125 & 4248.8 \\ -5.79 & 8.13 & 3.52 & 96 & 461 & 1,840,462 & 812,890 & 4248.8 \\ -5.57 & 7.28 & 3.88 & 259 & 340 & 1,839,670 & 812,873 & 4249.0 \\ -4.28 & 4.73 & 3.83 & 15 & 90 & 1,840,027 & 813,025 & 4250.3 \\ & & & & & & \\ -5.75 & 6.13 & 5.37 & 41 & 76 & 1,842,610 & 816,886 & 4237.9 \\ -1.24 & 3.26 & 1.24 & 100 & 404 & 1,842,958 & 816,759 & 4242.4 \\ & & & & & & & \\ -5.61 & 5.83 & 5.39 & 135 & 44 & 1,842,958 & 816,759 & 4242.4 \\ -13.85 & 14.02 & 13.68 & 354 & 34 & 1,842,924 & 816,824 & 4234.1 \\ & & & & & & & \\ -4.69 & 4.94 & 4.44 & 342 & 50 & 1,842,974 & 816,711 & 4247.1 \\ -5.26 & 4.67 & 4.26 & 353 & 41 & 1,842,969 & 816,759 & 4242.4 \\ -18.06 \text { not equilibrated } & & & & & & \\ & & & & & & & \\ & & & & & 1,840,441 & 817,579 & 4242.9 \\ -8.97 & 9.5 & 8.44 & 0 & 106 & 1,840,441 & 817,685 & 4234.0 \\ -8.97 & 8.45 & 8.39 & 0 & 6 & 1,840,441 & 817,585 & 4234.0 \\ -10.65 & 11.47 & 9.8 & 346 & 167 & 1,840,400 & 817,741 & 4232.3 \\ -13.25 & 13.35 & 13.14 & 180 & 21 & 1,840,441 & 817,558 & 4229.7 \\ -7.67 \text { na } & \text { na } & \text { na } & & & 1,840,441 & 817,685 & 4226.3\end{array}$




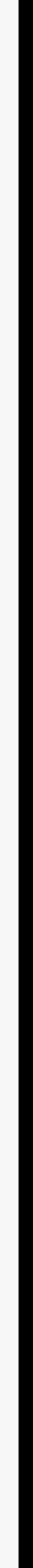

